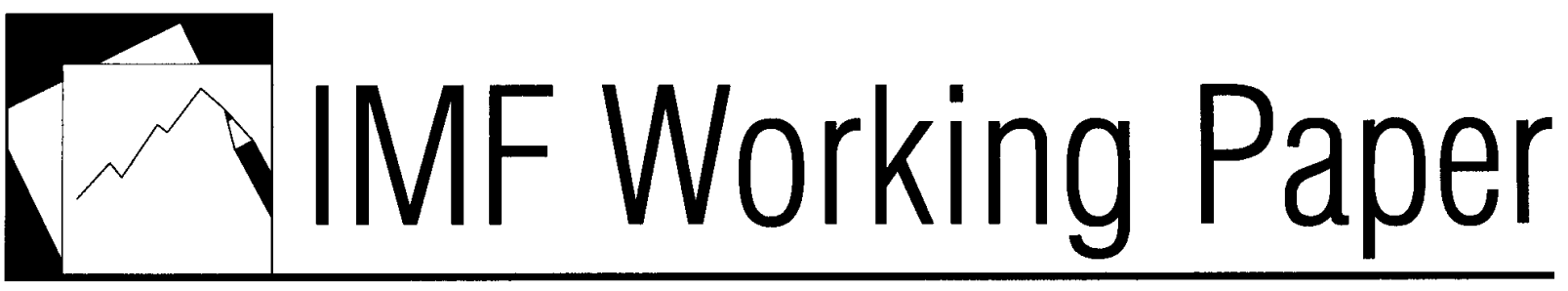

\title{
Weathering the Global Storm: The Benefits of Monetary Policy Reform in the LA5 Countries
}

Jorge Iván Canales-Kriljenko, Luis I. Jácome, Ali Alichi, and Ivan Luís de Oliveira Lima 


\title{
IMF Working Paper
}

Monetary and Capital Markets and Western Hemisphere Department

\author{
Weathering the Global Storm: The Benefits of \\ Monetary Policy Reform in the LA5 Countries
}

Prepared by Jorge Iván Canales-Kriljenko, Luis I. Jácome H., Ali Alichi, and Ivan Luís de Oliveira Lima ${ }^{1}$

Authorized for distribution by Karl Habermeier and Gilbert Terrier

December 2010

\begin{abstract}
This Working Paper should not be reported as representing the views of the IMF. The views expressed in this Working Paper are those of the author(s) and do not necessarily represent those of the IMF or IMF policy. Working Papers describe research in progress by the author(s) and are published to elicit comments and to further debate.

This paper highlights that central banks from Brazil, Chile, Colombia, Mexico, and Peru (the LA5 countries) reaped the benefits of what they sowed in successfully weathering the global crisis. The adoption of far-reaching institutional, policy, and operational reforms during the last two decades enabled central banks to build credibility about their commitment with the objective of price stability. Thus, when the 2007-08 supply shock and the financial crisis hit the world, the LA5 central banks reacted swiftly and effectively based on a flexible policy framework and with the support of strong macroeconomic and financial foundations. Building on the experience of the LA5 central banks and complementing with recommendations from the IMF's technical advice, the paper provides several suggestions for countries seeking to strengthen the effectiveness of monetary policy.
\end{abstract}

JEL Classification Numbers: E52, E58, E61

Keywords: Latin America, monetary policy, inflation targeting

Author’s E-Mail Address:jcanaleskriljenko@imf.org; ljacome@imf.org; aalichi@imf.org; ioliveiralima@imf.org

\footnotetext{
${ }^{1}$ This paper has benefited from the comments and suggestions of many colleagues at the IMF, in particular, from Simon Gray, Karl Habermeier, Steve Phillips, Scott Roger, Mark Stone, Gilbert Terrier, and Rodrigo Valdés. Errors and omissions are responsibility of the authors.
} 


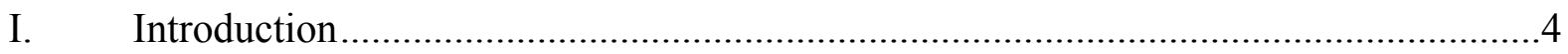

II. Building Blocks for Increasing Monetary Policy Effectiveness ...............................5

A. Enhancing Central Bank Autonomy and Accountability...............................5

B. Adopting an Appropriate Monetary Policy Framework ....................................

C. Improving the Operational Framework ................................................. 10

III. The New Monetary Framework at Work ................................................................. 12

A. Lower Macro-financial Vulnerabilities...........................................................12

B. Coping with the Surge in Commodity and Food Prices ..................................15

C. Dealing with the Global Financial Crisis Following the Lehman Collapse ....23

D. Relative Inflation Performance of Flexible Frameworks.................................37

IV. Suggestions for Enhancing Credibility and Moving toward Increased Monetary

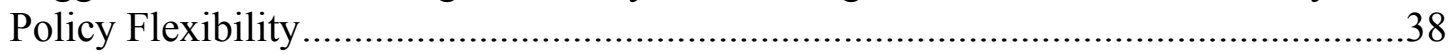

Tables

1. Key Institutional Arrangements for IT in LA5 Countries as of end-2009 ........................6

2. Central Bank Autonomy in LA5 and in Other Countries as of 2009............................... 7

3. Criteria behind the CWNE Index in the LA5 and Other Groups of Countries....................8

4. Key Parameters About IT Regimes in LA5 Countries as of end-2009.............................9

5. LA5 Central Banks' Transparency .............................................................................

6. Policy Rate Cuts by LA5 Central Banks in 2009 .........................................................29

Figures

1. LA5 Financial Soundness Indicators .....................................................................15

2. Inflation and Policy Rates in the Wake of the Supply and Financial Shocks.....................17

3. Monetary Policy Transmission, Policy and Bank Interest Rates ...................................... 18

4. Monetary Policy Transmission, Policy and Real Bank Interest Rates..............................19

5. Commodity Prices and Consumer Price Indices.......................................................20

6. Inflation and Central Banks' Interest Rates in Latin America.......................................21

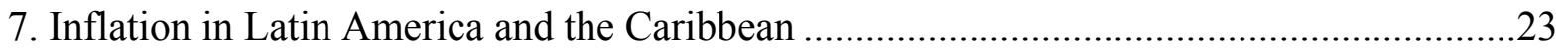

8. Central Bank Assets in LA5 and Selected Industrial Countries ......................................25

9. LA5 External Adjustment after Lehman's Collapse.......................................................27

10. Exchange Rate Passthrough, Consumer Price Inflation and Currency Depreciation ........28

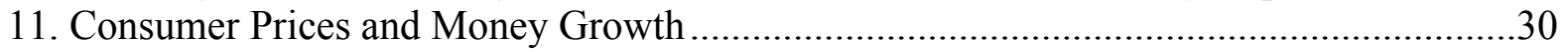

12. Monetary Developments and Private Credit Growth................................................. 31

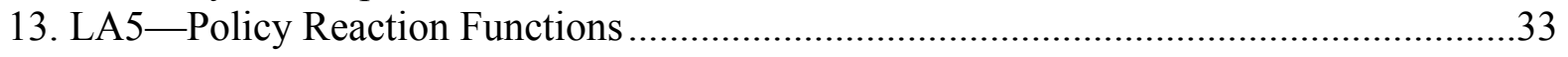

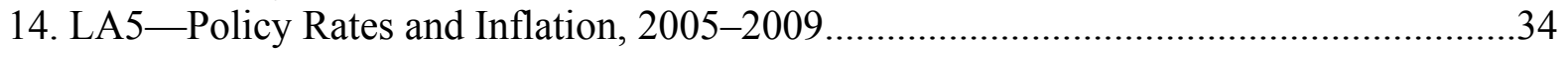

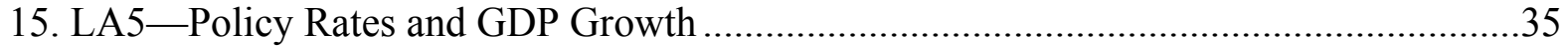

16. LA5 Inflation Rates and Inflation Expectations ........................................................ 37 
Boxes

1. The Transition from a Quantity to a Price Operational Target in Mexico and Peru ..........11

2. Other Measures Aimed at Coping with the Rise in Commodity and Food Prices ..............22

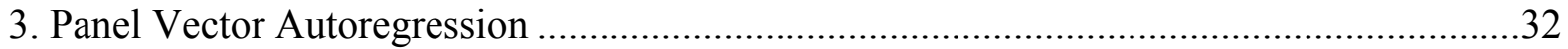

Appendices

I. Key Institutional and Policy Provisions in LA5 Central Banks ....................................46

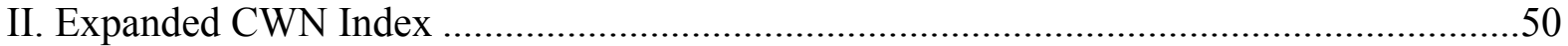

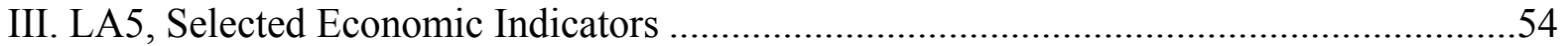

IV. Summary of Latin American Central Bank Responses to the Global

Financial Crisis 


\section{INTRODUCTION}

Countries in Latin America know from experience the cost of macroeconomic and financial instability. Many have gone through recurrent crises that took a large toll on economic growth and fueled social unrest. These crises were often triggered by exogenous shocks, which unveiled macroeconomic and/or financial vulnerabilities, often leading to simultaneous banking and currency collapses. ${ }^{2}$ The crises caused social frustration, as vast groups of the population lost their jobs, real income, and savings.

Since the late 1990s, many Latin American countries have substantially improved their macroeconomic and financial policies. Improved macroeconomic policies resulted in larger international reserves, lower external debt, and better public debt profiles. Latin American countries have also strengthened their regulatory and supervisory frameworks and thus reduced vulnerabilities in domestic financial institutions.

Many Latin American countries also adopted far-reaching structural reforms, including the approval of new central bank laws. The new legislation increased the autonomy of central banks and focused their mandate in preserving price stability. In return, central banks were held accountable for the enhanced delegated authority they received and directly in relation to their policy targets.

Based on these institutional foundations, a few Latin American countries were among the pioneers in significantly improving their monetary policy frameworks by adopting an inflation targeting framework. In particular, Brazil, Chile, Colombia, Mexico, and Peru (the LA5 countries) adopted inflation targeting (IT) between 1999 and 2002. This framework provided flexibility to monetary policy and became an alternative to exchange rate management or the use of traditional money targeting as a nominal anchor.

With stronger institutional underpinnings and with the support of their IT framework, the LA5 central banks built up credibility on the conduct of monetary policy. In a region battered by decades of very high inflation - Brazil and Peru had posted four-digit rates in the early 1990 s - the LA5 central banks managed to anchor inflation expectations during the current decade. As a result, they gained credibility as institutions committed with the objective of price stability.

A credible monetary policy, with the support of stronger macroeconomic and financial foundations, enabled the LA5 to manage successfully significant stress during the recent global crisis. Thanks to the flexibility of the IT frameworks, central banks reacted quickly and decisively to cope with the effects of the surge in commodities and food prices worldwide in 2007-2008 and subsequently with the impact of the financial crisis in the industrial world.

\footnotetext{
${ }^{2}$ See Kaminsky and Reinhart (1998 and 1999), which includes, in the sample, several Latin American crises from the 1980s to mid-1990s, and Jácome (2008) for financial crises that occurred from the mid-1990s onward.
} 
This paper highlights the major elements of central bank reform in the LA5 countries and the benefits of monetary policy credibility, in particular in the wake of the recent adverse external environment. The experience of LA5 central banks can be useful for countries seeking to enhance monetary policy effectiveness and to be better prepared to cope with recurrent external shocks. The paper is structured as follows: Section II briefly describes the reforms adopted by the LA5 central banks, including in the institutional, policy, and operational areas. Section III documents how LA5 central banks used the enhanced monetary policy flexibility to respond to the inflationary pressure arising from high food and fuel prices and later to sudden capital outflows and the deflationary pressures arising from the global financial crisis. Section IV reflects on the Latin American experience and the literature at large to provide key recommendations and suggestions for other central banks that aim to boost monetary policy effectiveness.

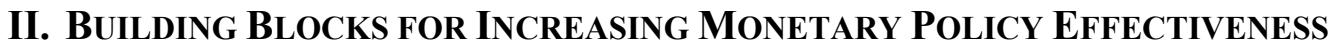

During the last 20 years, LA5 central banks undertook a comprehensive macroeconomic and financial sector reform. Significant institutional, policy, and operational changes took place (see Appendix 1). Four of the five countries approved new central bank legislation. ${ }^{3}$ All five central banks adopted IT and enhanced the use of market-based instruments to conduct monetary policy. These reforms improved the capacity of central banks to conduct effective monetary policy, which helped reduce inflation to historical low rates. ${ }^{4}$ Over time, the LA5 central banks built credibility and gained a reputation of being committed to price stability, which was critical for weathering the recent crisis without experiencing major macroeconomic disarray.

\section{A. Enhancing Central Bank Autonomy and Accountability}

New legislations strengthened central banks' autonomy. ${ }^{5} \mathrm{New}$ laws gave most central banks the primary mandate to focus on preserving price stability and provided central banks with political independence to take monetary policy decisions as needed to achieve their mandate. A milestone in the reform adopted in most countries was to delink monetary policy decisions from the political cycle, by appointing central bank board members for a longer period than - or in overlap with - the presidential term. In addition, some laws limited and others banned the central bank from lending to the government. The laws also granted central banks the freedom to choose the monetary operations they judged suitable to reach their stability goals. To conduct monetary policy, most LA5 central banks were assigned goal and instrument autonomy (Table 1), a practice not common in advanced IT countries, where most

\footnotetext{
${ }^{3}$ A new central bank law was passed in Chile (1989), Colombia (1992), Mexico (1993), and Peru (1993). Although Brazil did not pass a new central bank law, it strengthened the foundations of monetary policy by approving a lower-rank legislation to establish inflation targeting in 1999.

${ }^{4}$ In lowering inflation, maintaining fiscal policy in check was equally important.

${ }^{5}$ For a comprehensive analysis of central banks' reform in Latin America, see Carstens and Jácome, 2005.
} 
central banks enjoy only instrument autonomy. ${ }^{6}$ This autonomy was compounded with the governments' obligation to preserve central banks' capital integrity, except in Mexico.

The laws put the central bank boards in charge of making the policy decisions. In contrast to the LA5, in other IT central banks, a monetary policy committee performs this task (e.g., Korea, New Zealand, Thailand, South Africa, and the United Kingdom). ${ }^{7}$ The governing arrangement of the LA5 central bank boards differs slightly from those in many other IT central banks. Except for Peru, the boards are comprised of full-time members, as opposed to some other IT central banks in advanced countries and emerging markets, where the board also includes external members (for instance, the United Kingdom, Australia, Hungary, Poland, and the Philippines). In addition, in Colombia, the Minister of Finance chairs the board and in Chile the minister can participate in board sessions without casting votes. $^{8}$

Table 1. Key Institutional Arrangements for IT in LA5 Countries as of end-2009

\begin{tabular}{|c|c|c|c|c|c|c|}
\hline Countries & $\begin{array}{l}\text { Adoption } \\
\text { date }\end{array}$ & $\begin{array}{c}\text { Type of central } \\
\text { bank autonomy }\end{array}$ & $\begin{array}{l}\text { Decision- } \\
\text { making } \\
\text { body }\end{array}$ & \multicolumn{2}{|c|}{$\begin{array}{l}\text { Composition of } \\
\text { the CB Board }\end{array}$} & $\begin{array}{c}\text { Frequency of } \\
\text { policy } \\
\text { meetings }\end{array}$ \\
\hline Brazil & Jun. 1999 & Instrument & CB Board & $\begin{array}{c}8 \\
\text { internal }\end{array}$ & & Every 6 weeks \\
\hline Chile & Sep. 1999 & $\begin{array}{l}\text { Target + } \\
\text { instrument }\end{array}$ & CB Board & $\begin{array}{c}5 \\
\text { internal }\end{array}$ & & Monthly \\
\hline Colombia & Sep. 1999 & $\begin{array}{c}\text { Target + } \\
\text { instrument }\end{array}$ & CB Board & $\begin{array}{c}6 \\
\text { internal }\end{array}$ & $\mathrm{MoF}^{\mathrm{b} /}$ & Monthly \\
\hline Mexico & Jan. 2001 & $\begin{array}{l}\text { Target + } \\
\text { instrument }\end{array}$ & CB Board & $\begin{array}{c}5 \\
\text { internal }\end{array}$ & & Monthly \\
\hline Peru & Jan. 2002 & $\begin{array}{c}\text { Target }+ \\
\text { instrument }\end{array}$ & CB Board & $\begin{array}{c}1 \\
\text { internal }\end{array}$ & $\begin{array}{c}6 \\
\text { external }\end{array}$ & Monthly \\
\hline
\end{tabular}

a/ Central banks have target autonomy when they set the inflation target without necessarily agreeing with the government. Central banks have - only_instrument autonomy when they are free to choose the policy means to achieve the target.

b/ Refers to the Minister of Finance.

The new laws also strengthened central bank accountability to the markets and the society at large. Central banks became responsible for achieving inflation targets and for disclosing and explaining their policies and goals (see Appendix 1). Most central bank laws require central

\footnotetext{
${ }^{6}$ Goal autonomy grants the central bank independent authority to define the ultimate objectives of monetary policy such as price stability. Instrument or operational autonomy gives the central bank independent authority to use or set its monetary policy instruments to achieve its inflation target (see Heenan and others, 2006). We do not suggest that having target and instrument autonomy works necessarily better always and everywhere. For instance, in Australia, Canada, New Zealand, and the United Kingdom, the target for inflation is set either by the government or by the government and the central bank and it has proved to work well.

${ }^{7}$ For an updated review of governance arrangements in IT central banks, see Rogers (2009).

${ }^{8}$ However, the Minister is empowered to request the adoption of specific policies and can even suspend for up to two weeks any decision taken by the board, unless such decision is ratified unanimously in the same session.
} 
bank governors to explain monetary policy and inflation developments and outlooks to the legislative body. Before the legal reform, central banks only needed to prepare and publish an annual report. In practice, these reports did not help decision making of market participants or guide inflation expectations.

The autonomy and accountability of LA5 central banks is high compared to that of central banks in other developing and emerging market countries. Following the legal reforms, the autonomy and accountability of LA5 central banks increased substantially, and using a metric similar to that used in the literature, arguably tripled. ${ }^{9}$ The index we have used weighs legal provisions that strengthen autonomy and accountability and, hence, expands the Cukierman and others index that only focuses on the autonomy of central banks (Appendix 2). ${ }^{10}$ Today, the LA5 central banks are among the most autonomous central banks in Latin America and are, at least, similar compared to other important emerging market central banks that also sharply changed their central bank legislation (Table 2). On average, they rank better than the other 10 countries in our sample under the vast majority of criteria included in the autonomy index (Table 3$).{ }^{11}$

Table 2. Central Bank Autonomy in LA5 and in Other Countries as of 2009

\begin{tabular}{cccccc}
\hline LA5 countries & CWNE index & $\begin{array}{c}\text { Other LA } \\
\text { countries }\end{array}$ & CWNE index & $\begin{array}{c}\text { Other selected } \\
\text { IT countries }\end{array}$ & CWNE index \\
\hline Brazil $\left(^{*}\right)$ & 0.81 & Argentina & 0.77 & Czech & 0.86 \\
Chile & 0.95 & $\begin{array}{c}\text { Costa Rica } \\
\text { Colombia }\end{array}$ & 0.63 & $\begin{array}{c}\text { Indonesia } \\
\text { Poland }\end{array}$ & 0.91 \\
Peru & 0.82 & $\begin{array}{c}\text { Dominican } \\
\text { Rep. }\end{array}$ & 0.82 & 0.85 \\
Mexico & 0.86 & $\begin{array}{c}\text { Guatemala } \\
\text { Uruguay }\end{array}$ & 0.74 & Thailand & 0.75 \\
\hline
\end{tabular}

Source: IMF's central bank legislation data base and authors' calculations.

$\left.{ }^{*}\right)$ It incorporates the provisions from the presidential decree that established the inflation targeting regime in 1999.

\footnotetext{
${ }^{9}$ For earlier estimates, i.e. the pre-reform status, see Jácome and Vázquez (2008).

${ }^{10}$ See Cukierman and others (1992). The index used in this paper also takes on board important institutional trends that are currently considered best practices worldwide regarding central bank autonomy and accountability.

${ }^{11}$ These indices are based on de jure indicators of autonomy and accountability of central banks, and in practice actual autonomy and accountability may differ de facto from what the indices suggest. For instance, although the Central Bank of Brazil appears to be the less autonomous among the LA5 central banks, this may not necessarily so, since monetary policy seems to also be formulated and executed independently of any political influence as in the other LA5 countries.
} 
Table 3. Criteria behind the CWNE Index in the LA5 and Other Groups of Countries

\begin{tabular}{cccc}
\hline $\begin{array}{c}\text { CWNE index and its } \\
\text { components }\end{array}$ & $\begin{array}{c}\text { Average LA5 } \\
\text { Countries }(*)\end{array}$ & $\begin{array}{c}\text { Average other } \\
\text { LA countries }\end{array}$ & $\begin{array}{c}\text { Average other } \\
\text { selected IT }\end{array}$ \\
\hline Central Bank Board & 0.73 & 0.49 & 0.55 \\
Mandate & 1.00 & 0.70 & 0.96 \\
Policy formulation & 0.92 & 0.97 & 0.87 \\
Lending to government & 0.93 & 0.83 & 0.83 \\
Financial autonomy & 0.76 & 0.68 & 0.51 \\
Accountability & 0.77 & 0.84 & 0.63 \\
Total CWNE index & 0.86 & 0.75 & 0.74 \\
\hline
\end{tabular}

Source: IMF's central bank legislation data base and authors' calculations.

(*) In the case of Brazil, it incorporates the provisions from the presidential decree that established the inflation targeting regime in 1999.

\section{B. Adopting an Appropriate Monetary Policy Framework}

With a clear mandate on price stability, each of the LA5 central banks adopted an IT regime as their new monetary policy framework. IT provided an anchor for inflationary expectations and allowed for increased monetary policy flexibility, including on the exchange rate front. The central banks refined their IT frameworks gradually over a decade. To measure monetary policy success, they all chose inflation target ranges or a point inflation target with some tolerance bands. ${ }^{12}$ The targets are set indefinitely, except in Brazil and Colombia, where the central banks review and may change the inflation target annually. They all used the consumer price index as the target measure. The horizon for bringing inflation back on target is one year, except in Chile, where it is up to two years (Table 4). ${ }^{13}$

The new policy framework also required some reorganization of relevant central bank departments. For instance, the Central Bank of Brazil created a new Research Department in 1999 to centralize macroeconomic modeling and inflation forecasting. ${ }^{14}$ Also, the Central Bank of Peru replaced in 2005 the existing sector-based organization (monetary, fiscal, external, real, and global) that responded to the logic of financial programming, with a process-based institutional arrangement comprising processes for macroeconomic statistics, the international economy, monetary policy, macroeconomic analysis, and research.

\footnotetext{
${ }^{12}$ Before introducing IT, some central banks had already set and announced a target for inflation for each fiscal year (Chile and Colombia since 1991), but these targets would eventually get into conflict with other relevant variables, like the exchange rate.

${ }^{13}$ See Gredig and others (2008) for a discussion on the rationale for inflation tolerance, applied to Chile in comparison to other IT countries.

${ }^{14}$ See Bogdanski and others, 2000.
} 
Table 4. Key Parameters about IT Regimes in LA5 Countries as of end-2009

\begin{tabular}{lccccc}
\hline Countries & $\begin{array}{c}\text { Last change of } \\
\text { inflation target }\end{array}$ & $\begin{array}{c}\text { Target for } \\
\text { inflation rate }\end{array}$ & $\begin{array}{c}\text { Target } \\
\text { measure }\end{array}$ & $\begin{array}{c}\text { Frequency of } \\
\text { revisions of inflation } \\
\text { target }\end{array}$ & $\begin{array}{c}\text { Horizon for } \\
\text { bringing inflation } \\
\text { back on target }\end{array}$ \\
\hline Brazil & Jun. 2003 & $4.5 \% \pm 2 \%$ & CPI & Every year ${ }^{\text {al }}$ & 1 year \\
Chile & Sep. 1999 & $2 \%-4 \%$ & CPI & No revisions & 2 years \\
Colombia & Oct. 2009 & $2 \%-4 \%$ & CPI & Every year ${ }^{\text {b/ }}$ & 1 year \\
Mexico & Jan. 2003 & $3 \% \pm 1 \%$ & CPI & No revisions & 1 year \\
Peru & Jan. 2002 & $2 \% \pm 1 \%$ & CPI & No revisions & 1 year \\
\hline
\end{tabular}

Source: Central banks' websites.

a/ In Brazil, the National Monetary Council (see Appendix 1) sets the inflation target for the end of each year

(t) by end-June of two years in advance (t-2).

$\mathrm{b} /$ The Bank of the Republic of Colombia has a long-run inflation target and reviews annually the inflation target for the following year.

\section{Table 5. LA5 Central Banks' Transparency}

(before and after adopting inflation targeting)

\begin{tabular}{|c|c|c|c|c|c|c|c|c|c|c|}
\hline & \multicolumn{2}{|c|}{ Brazil } & \multicolumn{2}{|c|}{ Chile } & \multicolumn{2}{|c|}{ Colombia } & \multicolumn{2}{|c|}{ Mexico } & \multicolumn{2}{|c|}{ Peru } \\
\hline & After & Before & After & Before & After & Before & After & Before & After & Before \\
\hline 1. Statutory objective ${ }^{* * /}$ & 0.5 & 0.5 & 1.0 & 1.0 & 1.0 & 1.0 & 1.0 & 0.5 & 1.0 & 1.0 \\
\hline $\begin{array}{l}\text { 2. Explicit numerical target for } \\
\text { inflation }\end{array}$ & 1.0 & 0.0 & 1.0 & 1.0 & 1.0 & 1.0 & 1.0 & 1.0 & 1.0 & 0.0 \\
\hline $\begin{array}{l}\text { 3. Central bank publishes surveys } \\
\text { markets use to estimate inflation } \\
\text { expectations }\end{array}$ & 1.0 & 0.0 & 1.0 & 0.0 & 1.0 & 0.0 & 1.0 & 0.0 & 1.0 & 0.0 \\
\hline $\begin{array}{l}\text { 4. The central bank publishes } \\
\text { forward-looking analyses such as } \\
\text { forecasts }\end{array}$ & 1.0 & 0.0 & 1.0 & 0.0 & 1.0 & 0.0 & 1.0 & 0.0 & 1.0 & 0.0 \\
\hline $\begin{array}{l}\text { 5. The central bank publishes } \\
\text { minutes of policy meetings }\end{array}$ & 1.0 & 0.0 & 1.0 & 0.0 & 1.0 & 0.0 & 0.0 & 0.0 & 0.0 & 0.0 \\
\hline $\begin{array}{l}\text { 6. The central bank publishes } \\
\text { voting patterns of policy meetings }\end{array}$ & 1.0 & 0.0 & 1.0 & 0.0 & 0.0 & 0.0 & 0.0 & 0.0 & 0.0 & 0.0 \\
\hline $\begin{array}{l}\text { 7. The central bank publishes } \\
\text { explanations the same day of } \\
\text { policy changes }\end{array}$ & 1.0 & 0.0 & 1.0 & 0.0 & 1.0 & 0.0 & 1.0 & 1.0 & 1.0 & 0.0 \\
\hline $\begin{array}{l}\text { 8. The central bank publishes } \\
\text { explanations the same day that } \\
\text { it decides no policy change }\end{array}$ & 1.0 & 0.0 & 1.0 & 0.0 & 1.0 & 0.0 & 1.0 & 0.0 & 1.0 & 0.0 \\
\hline $\begin{array}{l}\text { 9. The central bank publishes } \\
\text { discussions of risks to outlook or } \\
\text { forecasts }\end{array}$ & 1.0 & 0.0 & 0.5 & 0.0 & 1.0 & 0.0 & 1.0 & 0.0 & 1.0 & 0.0 \\
\hline $\begin{array}{l}\text { 10. The central bank publishes } \\
\text { discussions of shocks or forecast } \\
\text { errors after the facts }\end{array}$ & 1.0 & 0.0 & 1.0 & 0.0 & 1.0 & 0.0 & 1.0 & 0.0 & 1.0 & 0.0 \\
\hline Totals & 9.5 & 0.5 & 9.5 & 2.0 & 9.0 & 2.0 & 8.0 & 2.5 & 8.0 & 1.0 \\
\hline$\overline{\text { Differences (after - before) }}$ & & 9 & & .5 & & 7 & & 5 & & 7 \\
\hline
\end{tabular}

Source: Survey conducted to LA5 central banks.

*/ Questions asked in the survey and the coding of the answers correspond to the categories and the criteria in the transparency index by Crowe and Meade (2008).

**/ Based on central banks' legislation (not asked in the survey). 
LA5 central banks improved in communicating clearly the rationale of their policy strategy and individual policy decisions. Table 5 suggests that transparency in LA5 central banks has improved remarkably after each country adopted inflation targeting. ${ }^{15}$ After introducing IT, the LA5 central banks emphasized a forward-looking approach, explaining to market participants where monetary policy is heading. Since the beginning of the current decade, LA5 central banks prepare and publicly disclose inflation or monetary policy reports three or four times a year and, more recently, they also elaborate and disseminate financial stability reports. They decide the level of the policy rate during preannounced meetings, disclose the rationale behind their rate and other policy decisions, and some publish the minutes of their board meetings (Brazil, Chile, and Colombia). In general, LA5 central banks also constantly communicate with the market and issue press releases as needed. The Central Bank of Brazil created the Investors Relations Group in 1999 with the aim of enhancing two-way communication with the private sector, in particular with investors, to support the effectiveness of IT. Central banks also make available data on market views about key macroeconomic variables, in particular, about expectations on inflation and economic activity, as well as central bank forecasts. Similarly, LA5 central banks have produced some basic material to educate economic agents and made it available at their websites. ${ }^{16}$

\section{Improving the Operational Framework}

LA5 central banks revamped their operational frameworks. They have converged in choosing a short-term interest rate (the "policy rate") as their operational target. Central banks in Brazil, Chile, Mexico, and Peru chose a target for a market-based overnight interest rate as their policy rate. In turn, the Bank of the Republic of Colombia chose a central bank rate, namely the floor rate for the daily overnight liquidity injection auctions. The transition was swift in Brazil, Chile, and Colombia, but took longer in Mexico and Peru. Bank of Mexico adopted a policy rate as the operational target only in January 2008, after having followed some steps to replace its previous quantity-based operational target, the so-called "corto." The Central Bank of Peru, whose financial system is highly dollarized, adopted a policy rate as an operational target in late 2003, after going through a gradual transition from quantities to prices (Box 1). ${ }^{17}$

\footnotetext{
${ }^{15}$ The transparency index corresponds to the one used by Crowe and Meade (2008).

${ }^{16}$ Positive steps in this direction are Bank of Mexico's short note explaining inflation targeting (Esquema de Objetivos de Inflación) and a note on questions and answers about monetary policy in Mexico. In Brazil, the central bank has created in its website a section of frequently asked questions, directed to the general public, covering more than 40 areas, including questions and answers on the Brazilian inflation targeting regime (Regime de Metas para a Inflação no Brasil), on the monetary policy committee (Copom), and on public debt and open market operations (Gestão da Dívida Mobiliária e Operações de Mercado Aberto). The Central Bank of Chile prepared a comprehensive document explaining its monetary policy (La Política Monetaria en el Banco Central de Chile), although this document is more directed to a specialized audience.

${ }^{17}$ In other monetary policy regimes, the operational target varies. For instance, with a monetary-targeting regime in place, central banks typically target some money aggregate, like the money supply, whereas in an exchange rate-targeting regime, central banks may use the nominal exchange rate or a short-term interest rate as the intermediate target. See Habermeier and others (2009) for a taxonomy of monetary policy regimes.
} 


\section{Box 1. The Transition from a Quantity to a Price Operational Target in Mexico and Peru}

Mexico: A gradual strategy guaranteed a smooth transition from a quantity to a price operational target in Mexico. From September 1995 onward, Banxico had been conducting monetary operations by defining a target for bank reserves (the "corto"). Since March 2004, Banxico monetary policy announcements have signaled the intended changes in "monetary conditions," which in practice have steered interbank overnight rates. Since then, the interbank market has in practice followed central bank signals for short-term interest rates, although the formal announcements were still in terms of the size of the "corto". Subsequently, Banxico has refrained from changing the "corto" even if it would sometimes alter its stance for the monetary conditions - the last move in the "corto" took place in March 2005. However, until January 2008, the Mexican central bank did not announce a target for the interbank overnight interest rate. Instead, it referred to tightening or loosening monetary conditions by a certain number of basis points. As it announced the formal move towards adopting the overnight interbank interest rate as its operational target, Banxico explained that the "corto" had successfully helped bring inflation down to 4 percent in 2003 from 52 percent in 1995 . However, the central bank needed to be more specific about the desired level for interest rates in an environment with more stability in financial markets and lower inflation. ${ }^{/ 1 / 2}$

Peru: Peru also adopted a gradual strategy to move from a monetary to an interest rate operational target. Until 2000 , monetary policy controlled money base growth. In the beginning of 2001, the BCRP changed its operational target to the aggregate balance of commercial banks' current accounts with the central bank. It also set a calendar of monetary policy meetings in which it announced the targeted range for the current account balance. In January 2002, Peru adopted inflation targeting as its monetary policy regime. Also in the beginning of 2002, the BCRP complemented the current account target by setting up a corridor for overnight interbank rates between the central bank's overnight deposit rate and rediscount rate. This corridor became the monetary policy operational variable in the beginning of 2003. In September 2003, the BCRP announced that it would target, through its open market operations, an interbank overnight interest rate close to the center of the corridor. The changes in the operational target reduced volatility of the interbank interest rate, and improved the transmission to longer term interest rates.

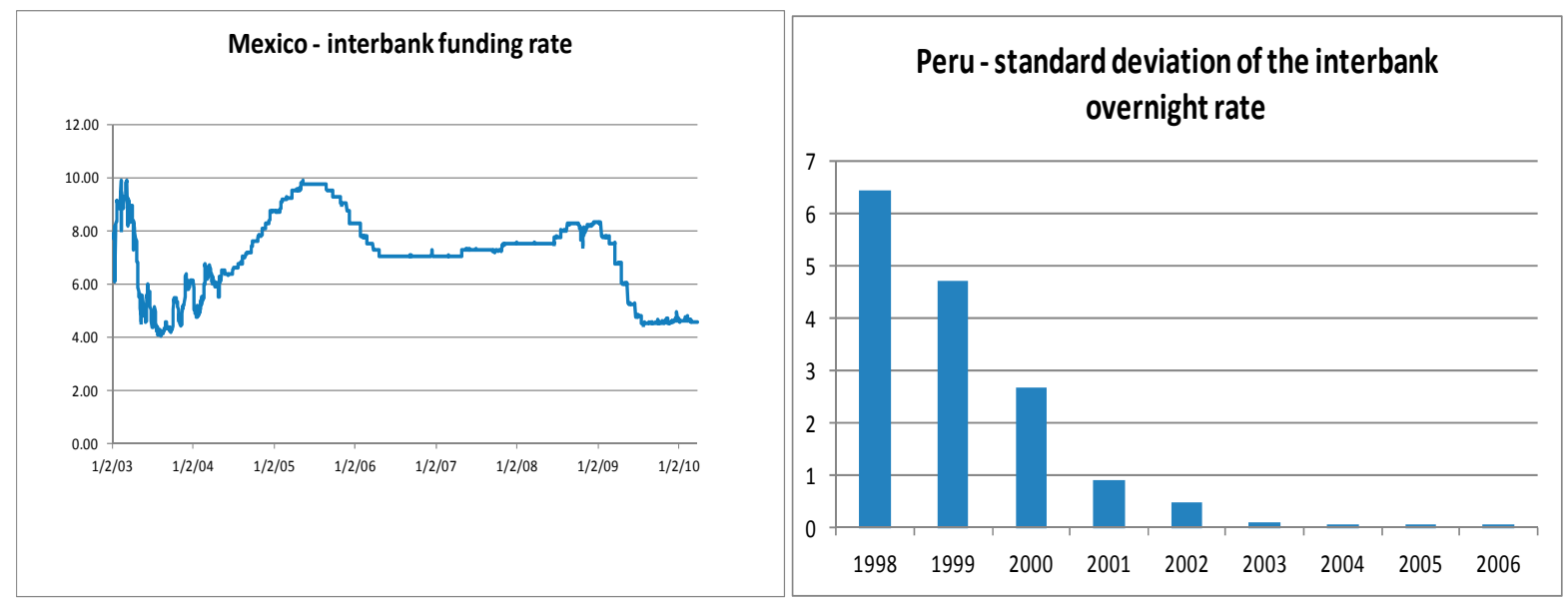

${ }^{1}$ See Banxico's document titled "Instrumentación de la Política Monetaria a través de un Objetivo Operacional de Tasa de Interés (Anexo 3 del Informe sobre Inflación Julio-Septiembre 2007).”

${ }^{2}$ The idea behind the adoption of a volume target, when the "corto" was introduced, was that inflation and interest rates were so high and volatile that a policy interest rate would hardly be relevant.

To drive short-term interest rates to the policy rate, LA5 central banks conduct open market operations. They borrow or lend bank reserves (which is usually known as liquidity management) to keep their demand and supply in equilibrium and interbank market rates close to the policy rate. The Bank of Mexico is a net lender and has a net asset position with 
banks, while the central banks of Brazil, Chile and Peru usually — although not always — are net borrowers and have a net liability. The Bank of the Republic of Colombia has had a net asset position most of the time in the last five years, which has occasionally turned to a net liability. All LA5 central banks use repos for lending domestic currency. The central banks of Chile and Peru issue their own securities to withdraw (borrow) liquidity. The Brazilian central bank resorts to reverse repos of government securities and the Bank of the Republic of Colombia issues term deposits. The Bank of Mexico also injects liquidity through collateralized credits (guaranteed by the compulsory deposits at the central bank).

Central banks rely on liquidity forecasting to guide their open market operations. They have developed efficient means to anticipate factors that could lead to liquidity imbalances, which could in turn cause market interest rates to deviate from policy rates. Such factors include government cash flows and central bank foreign exchange operations, among others. Coordination with the government bodies in control of government cash flows and public debt has been crucial in improving liquidity forecasting.

LA5 central banks have also set up an interest rate corridor around the policy rate, which helped keep market interest rates close to target. The ceiling and the floor of the corridor are standing facilities offered for liquidity provision and for liquidity absorption, respectively. For different countries, however, the widths of such corridors differ. Chile has the narrowest corridor while Mexico has the widest. When defining the corridor width, central banks weigh two opposing objectives. On the one hand, a wider corridor relies more on liquidity forecasting and open market operations to stabilize short-term rates. On the other hand, a narrower corridor provides a stricter automatic control over short-term market rates, but if too narrow, may inhibit interbank trading.

\section{The NeW Monetary FrameWORK AT WORK}

The second half of the 2000s tested and confirmed the LA5's commitment to inflation targeting. Based on stronger macroeconomic fundamentals than in the past and on buffer mechanisms put in place over several years, monetary flexibility played a key role to weather successive real and financial shocks. The LA5 monetary policy frameworks handled successfully large swings in real exchange rates. These were associated first with a politically challenging increase in food and fuel prices. Then, followed a sudden stop and reversal of capital inflows and a deflationary pressure associated with the global financial crisis.

\section{A. Lower Macro-financial Vulnerabilities}

The global crisis found the LA5 countries with relatively low macroeconomic vulnerabilities. By the early 2000s, the LA5 countries had already achieved low and stable inflation and had kept fiscal and external imbalances in check (see Appendix 3). Taking advantage of a commodity price boom and easy global financial conditions during 2003-07, the LA5 took the opportunity to reduce macroeconomic vulnerabilities. Their current account balances improved and they were able to build fiscal and external buffers that helped mitigate the 
negative effects of exogenous shocks. They also further improved public debt profiles and built up international reserves.

Foreign reserve coverage increased in most of LA5 over the decade before the global financial crisis. As a percent of GDP, international reserves increased substantially in Brazil and Peru, slightly in Mexico, and remained stable in Colombia. Although reserve coverage almost halved in Chile, it still stood at high levels. The increase in Chilean sovereign wealth funds provided extra insurance against a sudden stop or other sudden need of external liquidity. ${ }^{18}$ Methods to build up reserves varied, with some countries using methods that limit the impact on exchange rate flexibility, including through auctions for options (Mexico and Colombia) and pre-announcing the intended reserve buildup (Chile). ${ }^{19}$

The capital flow composition improved and external financing needs decreased. Foreign direct investment dominated capital flows, and debt flows declined sharply, reducing the share of external debt and annual external financing needs. In particular, median external financing needs halved as a percent of GDP in the decade before the global financial crisisto 6.8 percent of GDP in 2007 from about 15 percent of GDP in 1996.

Fiscal frameworks were significantly strengthened. All five countries adopted fiscal responsibility laws. Chile and Mexico also put in place a fiscal rule and Colombia has announced its intent to introduce one. These fiscal frameworks reflected a political will that helped reduce fiscal vulnerabilities. The public debt composition improved markedly, with major drops in the share of foreign currency-denominated debt and public debt issued abroad. Over the last decade, the behavior of public debt levels as a percent of GDP varied. Although the gross public debt to GDP ratio increased in Brazil, it fell significantly in Chile and Peru and moderately in Colombia and Mexico. ${ }^{20}$ In all countries, however, the public debt burden denominated in foreign currency and issued abroad fell substantially as a percent of GDP. The public external debt to GDP also fell slightly in all countries (See Appendix 3).

Prudential regulation and supervision were markedly upgraded. The improvements in financial soundness indicators noted earlier reflected not only good times from a favorable external environment but also, and more importantly, significant reforms in prudential regulation and banking supervision. These reforms imposed some prudence on financial institutions for managing the good times. Colombia and Peru also adopted measures to smooth credit growth along the cycle by adopting countercyclical loan-loss provisions. The LA5 made significant progress in the compliance with Basel core principles, although there

\footnotetext{
${ }^{18}$ Assets in the sovereign wealth funds from the government of Chile increased substantially (Céspedes and Valdés, 2006 and Ministerio de Hacienda de Chile, 2010). The sovereign wealth fund in Brazil also provided a form of self insurance against sudden stops.

${ }^{19}$ The method for building reserves matters. Central banks could borrow abroad long-term to purchase their desired level of insurance against sudden stops. Central bank foreign exchange purchases may end attracting more inflows given the reduced exchange rate risk that in turn lead to more intervention.

${ }^{20}$ The net public debt ratio to GDP fell in Brazil between 2000 and 2008.
} 
is still room for improvement. ${ }^{21}$ Most countries also took steps toward a gradual adoption of the Basel II Accord.

The soundness of the banking system increased. As opposed to several advanced countries, financial institutions in the LA5 countries were not exposed to toxic assets, at least in systemic amounts. In general, capital adequacy ratios largely exceeded the 8 percent minimum of the Basel Accord, averaging about 16 percent at the time of the Lehman events. Nonperforming loans had been declining to below 5 percent of total loans in the context of rapid credit growth. Bank profitability had also been increasing during the decade of the 2000s (Figure 1). The degree of financial dollarization in Peru, the only dollarized economy in the group, also fell substantially over the period, even after adjusting for the effect of currency appreciation. ${ }^{22}$

The better monetary, fiscal, and prudential frameworks were themselves a source of strength and lower macroeconomic vulnerabilities. Monetary policy frameworks had anchored expectations and granted the central bank more credibility. The more flexible exchange rate regimes made a significant difference, reducing the macroeconomic and financial effects of the real exchange rate appreciations. They helped avoid Krugman-type balance of payments crises when capital inflows suddenly reversed. Moreover, production and consumption suffered less than they would have if interest rates had needed to increase or remain high to defend the nominal exchange rate under a peg regime. In addition, the anchored inflation expectations allowed the public sector to increase the share of its debt denominated in local currency, which reduced sovereign exposures to exchange rate risk. Unlike in past episodes of financial turmoil, the stronger frameworks, lower vulnerabilities, and some good luck allowed the region to escape this time currency, banking, and/or public debt crises. ${ }^{23}$

\footnotetext{
${ }^{21}$ See Rennhack, 2009.

${ }^{22}$ For instance, the dollarization of credit to the private sector fell to 50 percent by May 2010 from about 80 percent in the late 1990s.

${ }^{23}$ Earlier episodes include the well-known early 1980s crisis that covered all Latin America, the late-1990s Russian crisis that hit Brazil and most Andean countries, the Mexican "tequila" crisis in the mid-1990s, and the 2002 Argentinean crisis that adversely affected certain Latin American countries. See Jácome (2008) for an analysis of the 1990s and 2000s financial crises in Latin America and their macroeconomic and financial consequences.
} 
Figure 1. LA5 Financial Soundness Indicators (2000-2009)

Regulatory capital to risk weighted assets

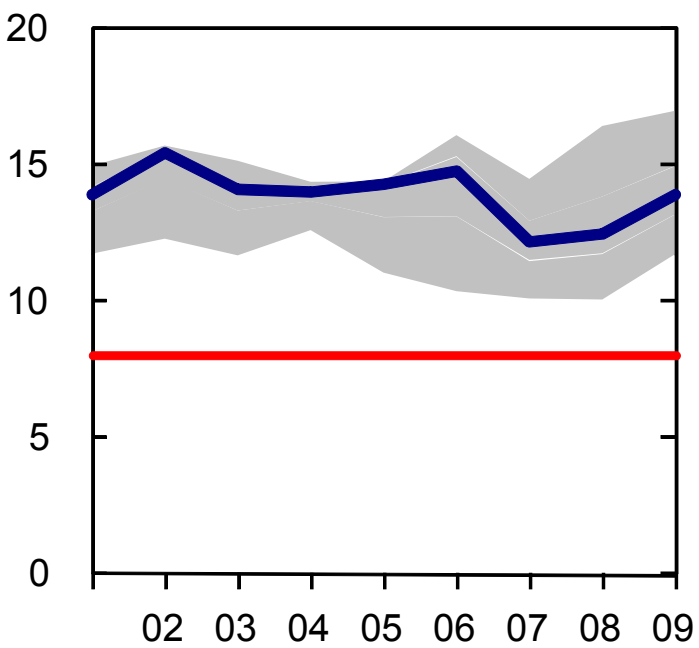

\section{Return on equity}

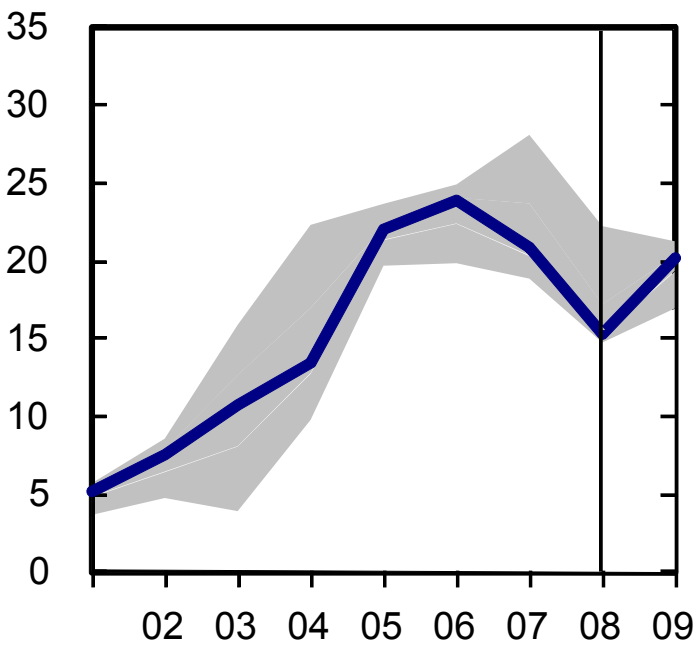

Nonperforming loans

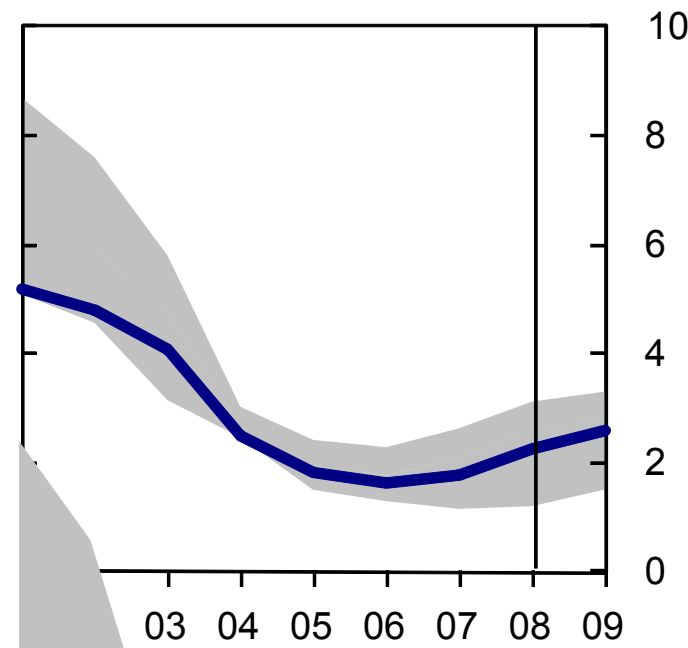

Return on assets

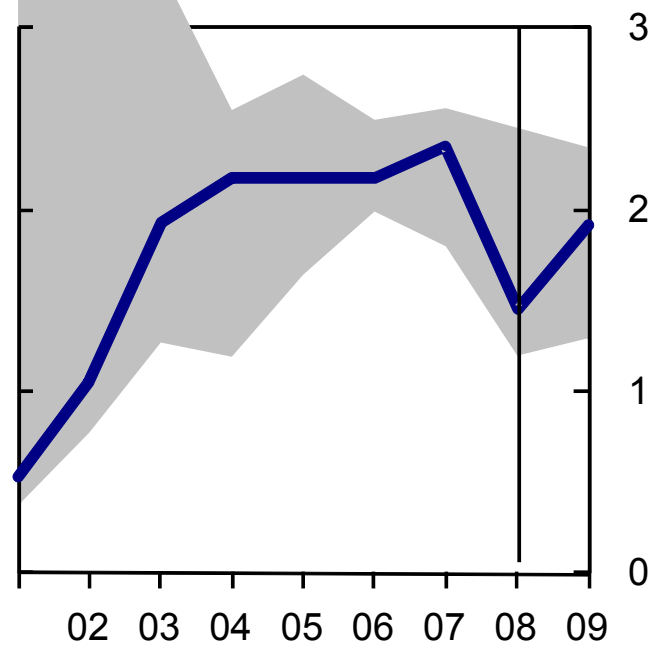

Sources: National authorities; and IMF staff calculations.

$1 /$ The official definition of soundness indicators vary by country. The solid lines indicate the median of the indicators across the countries in the group, while the shaded area contains the second to the fourth quintiles.

\section{B. Coping with the Surge in Commodity and Food Prices}

Before the recent global financial crisis exploded, the LA5 countries were facing rising inflation, as did the rest of the world. The inflationary pressures reflected a combination of rising costs and domestic demand. The cost-push associated with the surge in food and oil prices coincided with easy external financial conditions and favorable terms of trade that 
increased domestic demand, appreciated the domestic currency, and led to sharp increases in credit growth. Commodity and energy prices had been rising in world markets since the early 2000s, but they swelled in 2007 up to the first half of 2008. With fuel and food items accounting for a high percent of CPI baskets in LA5 countries and with rising demand, inflation started to increase, in particular in Chile and Colombia - where inflation rose to close to 10 percent and 8 percent, respectively, at the peak.

LA5 central banks reacted - with a short lag — by tightening monetary policy. The central bank of Colombia was the first to tighten and kept a policy of raising the policy rate (by 400 basis points) that had already started on 2006Q2. The Central Bank of Chile reacted swiftly since the beginning of 2007 raising the policy rate (by 325 basis points up to 2008Q3). Central banks in Peru, Brazil, and, in particular, Mexico increased their policy rate more gradually, but quickened the increases during 2008Q2 and 2008Q3 (Table 4). These policy rate hikes were transmitted to bank rates, which increased in real terms (Figures 2, 3, and 4). Initially, most central banks expected that the supply shock would be temporary and would not significantly affect core inflation. However, as the supply shocks became persistent, second-round effects started to kick in, thereby increasing core inflation (Figures 2 and 5). In some countries demand pressures also played a role as capacity constraints were binding (Brazil and Colombia) and credit was growing fast (Peru). ${ }^{24}$ On average, the increase in the policy rate started earlier in the LA5 than in other countries in Latin America (Figure 6).

Nominal exchange rates appreciated significantly in most LA5 countries as capital flowed in. Between January 2007 and mid-2008, most domestic currencies appreciated - by more than 30 percent - in particular in Brazil and Colombia. The appreciation helped to moderate imported inflation from the upsurge in worldwide food and energy prices. The policy interest rate hikes helped further contain the inflationary pressures, but at the same time encouraged short-term capital inflows and nominal appreciation. All central banks, except Mexico, intervened in the foreign exchange market. Some did it as part of a strategy of building up international reserves that would serve as a buffer to cope with a likely weakening of the external environment. Others to reduce volatility in the foreign exchange market. Some bought foreign exchange for both purposes.

\footnotetext{
${ }^{24}$ The same pattern of rising inflation took place in most emerging market countries at that time as documented in Habermeier and others (2009).
} 
Figure 2. Inflation and Policy Rates in the Wake of the Supply and Financial Shocks (Annual percentage rate)
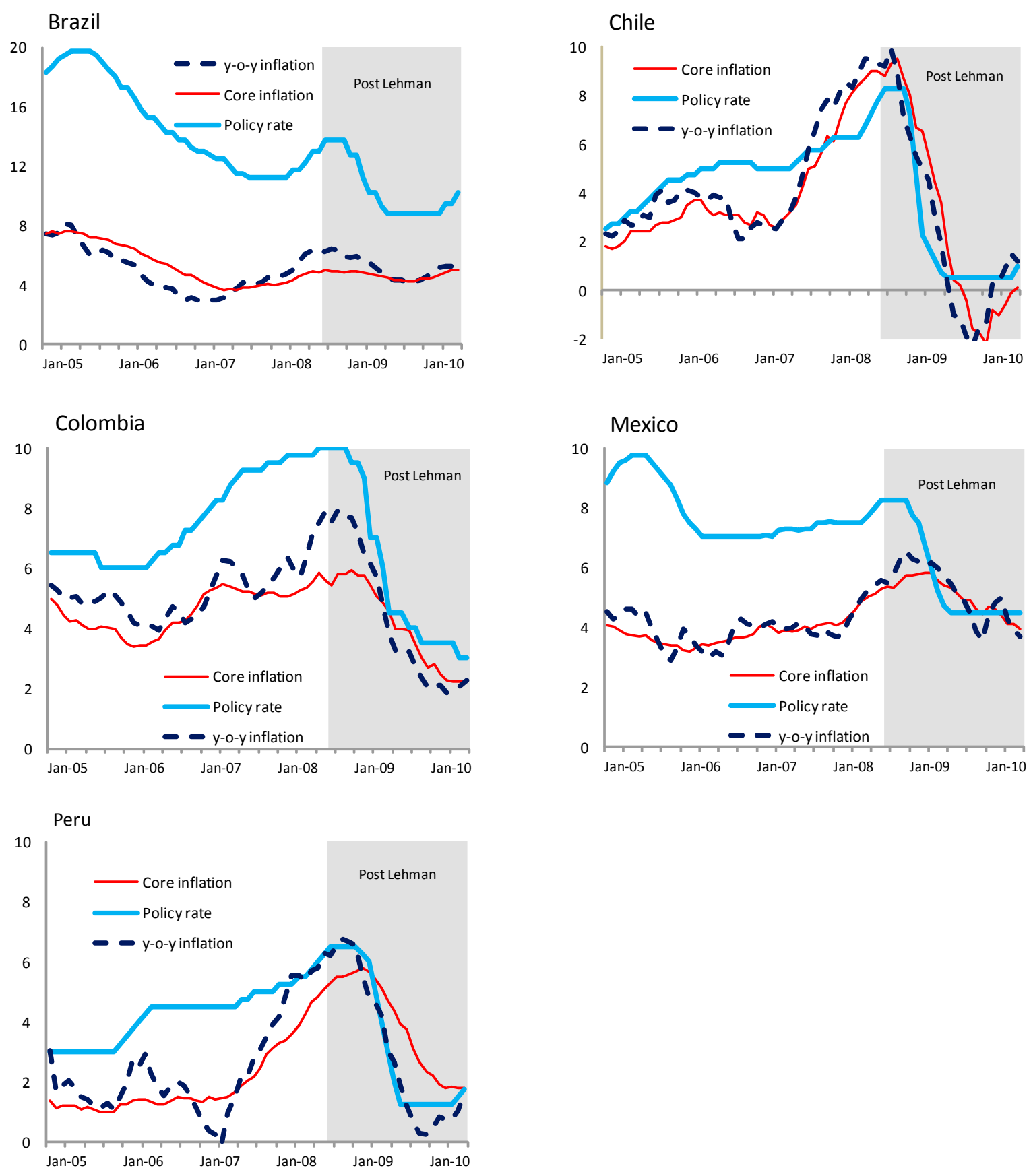

Source: LA5 central banks' websites. 
Figure 3. Monetary Policy Transmission, Policy and Bank Interest Rates (Annual percentage rate)

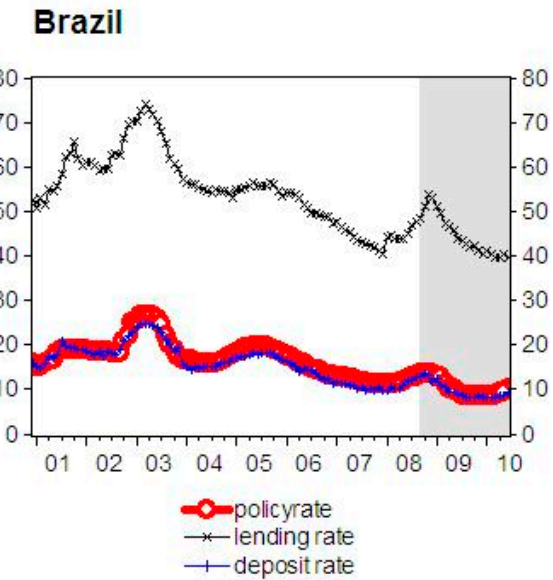

Colombia

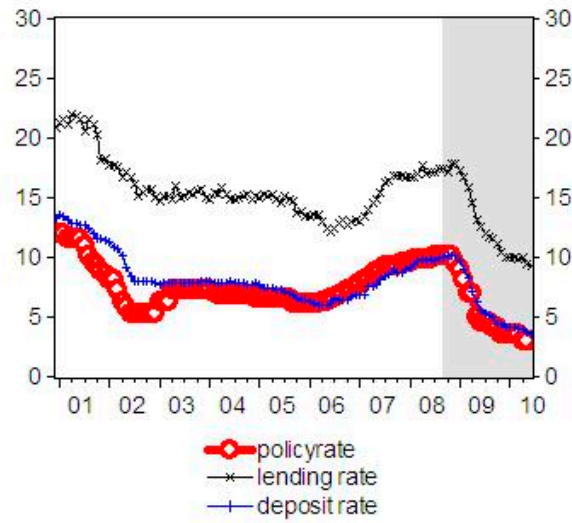

Peru

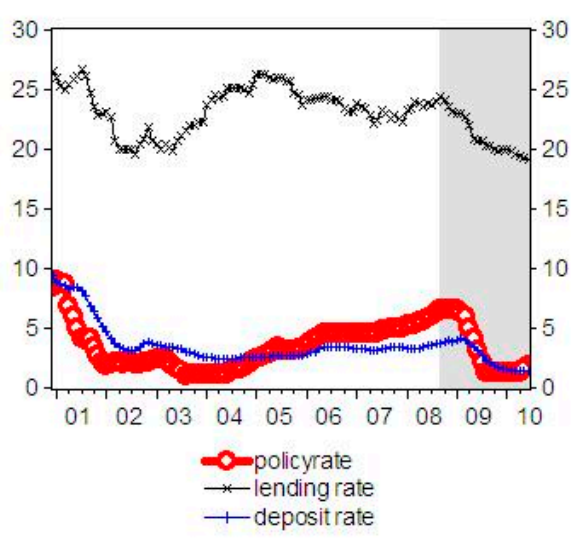

Chile

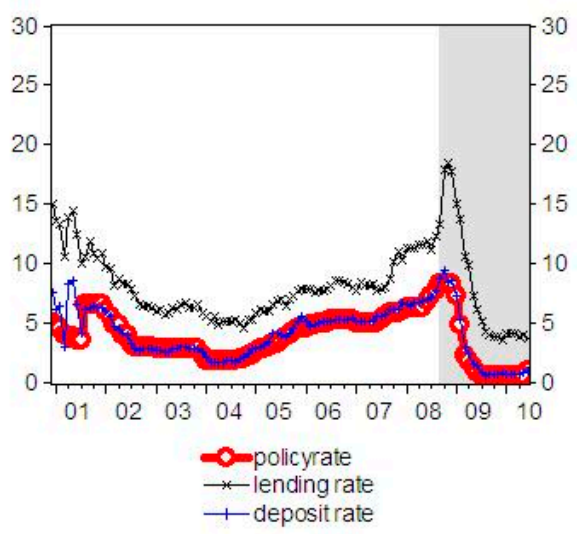

Mexico

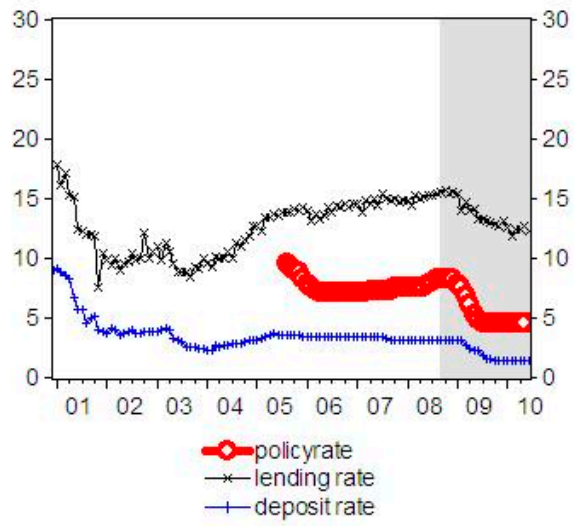


Figure 4: Monetary Policy Transmission, Policy and Real Bank Interest Rates ${ }^{25}$

(Annual percentage rate)

Brazil

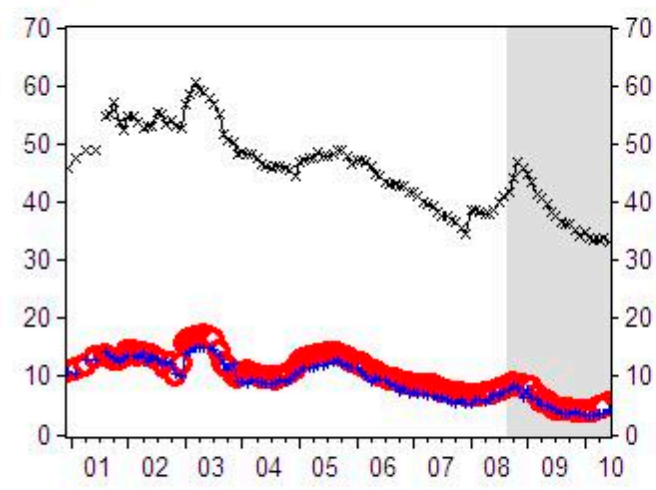

Colombia

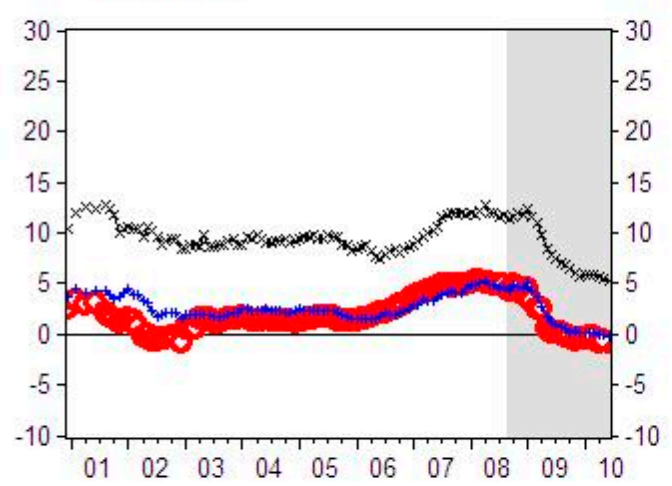

Peru

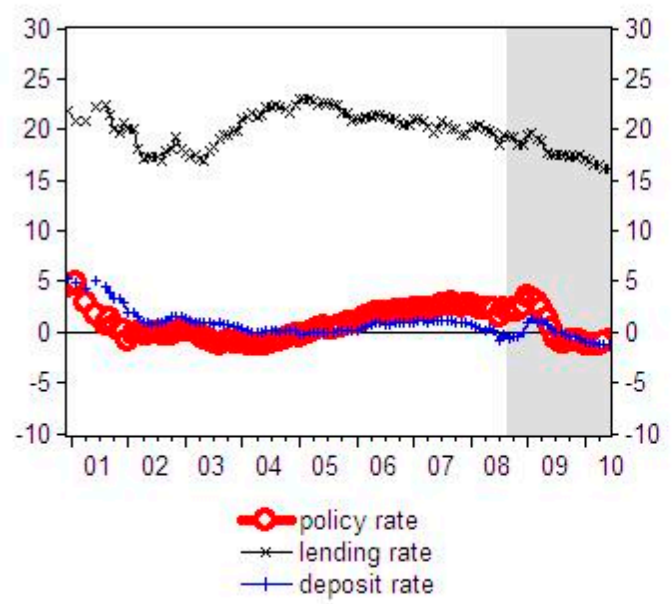

Chile

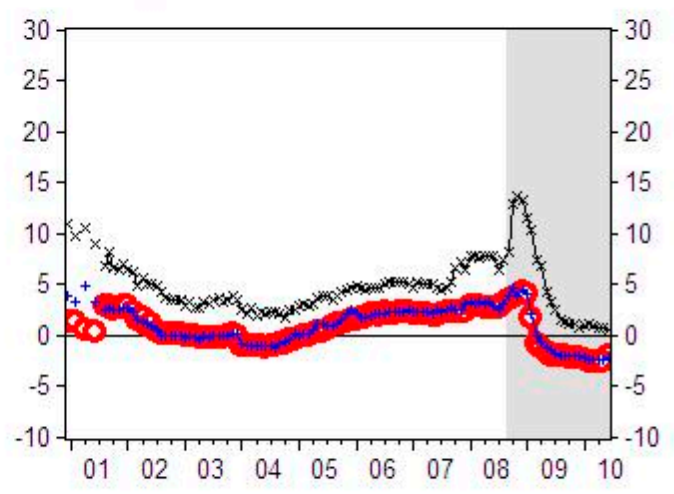

Mexico

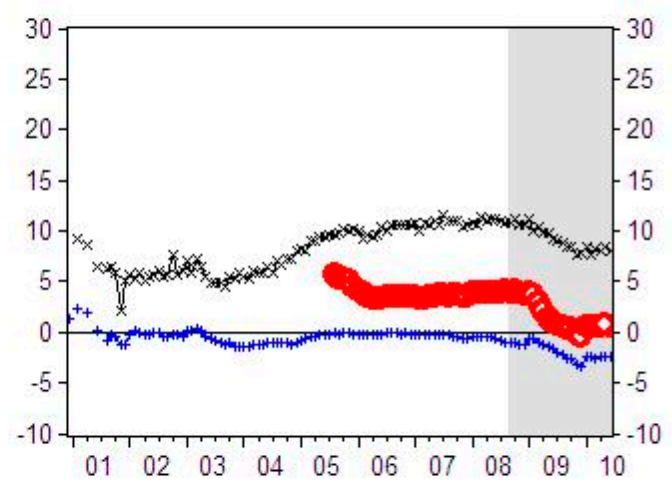

${ }^{25}$ Real interest rates are computed by using the expected inflation for the following calendar year, as reported by Consensus Economics. 
Figure 5: Commodity Prices and Consumer Price Indices

(CPI sub-indices of consumer prices expressed in U.S. Dollars, SA, September 2008=100)

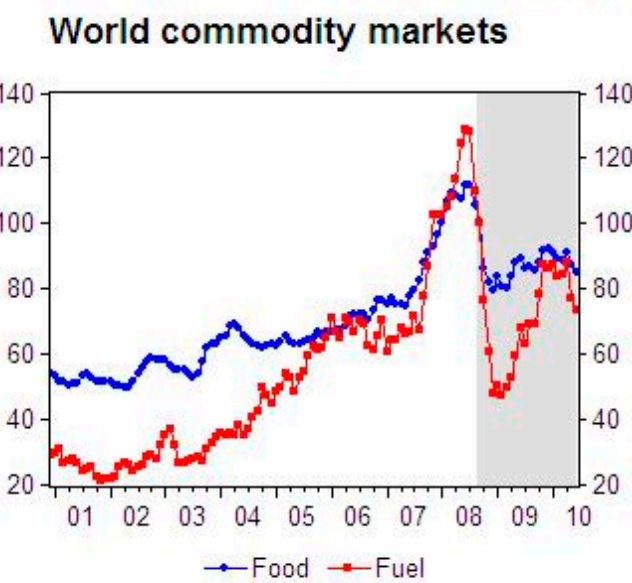

Chile

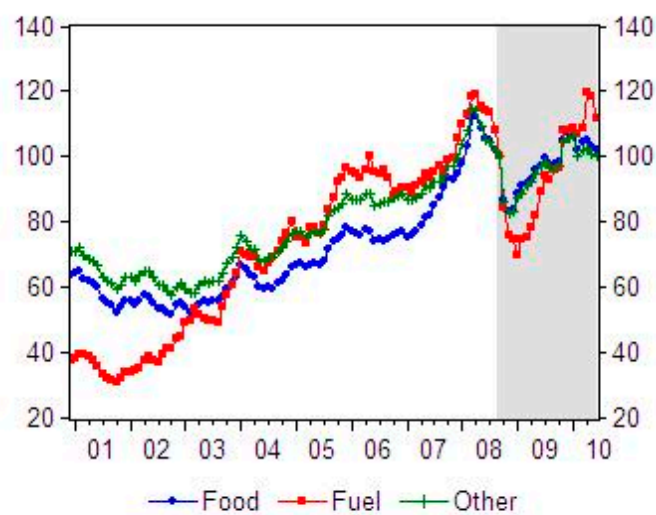

Mexico

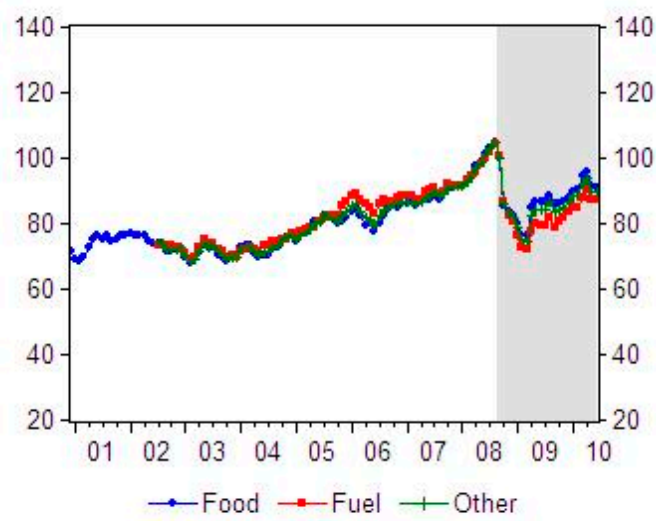

Brazil

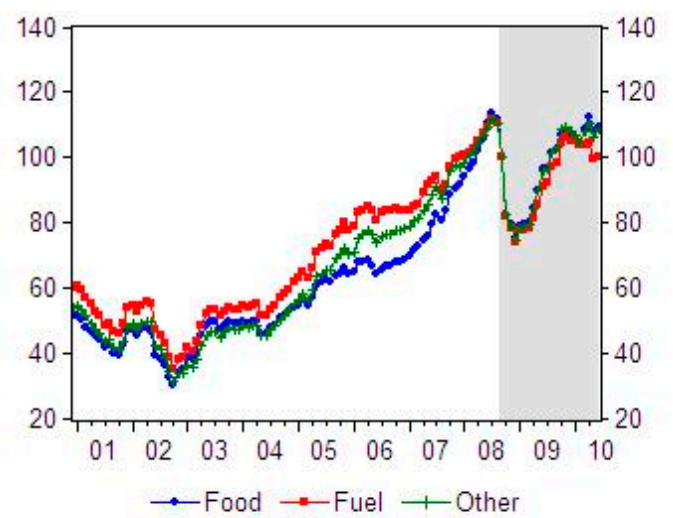

Colombia

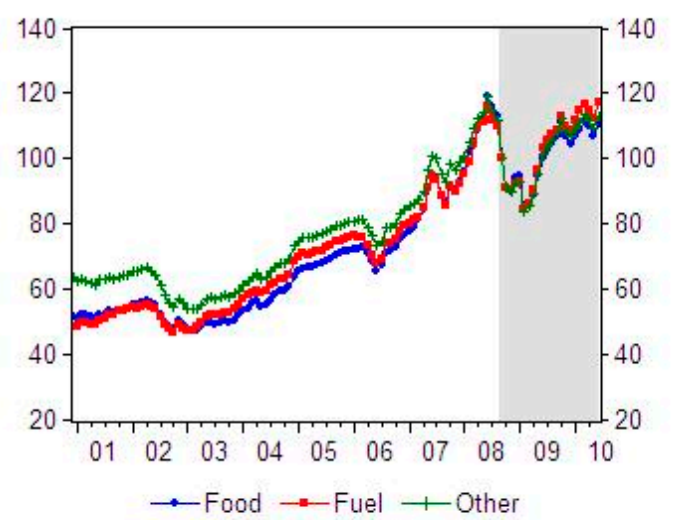

Peru

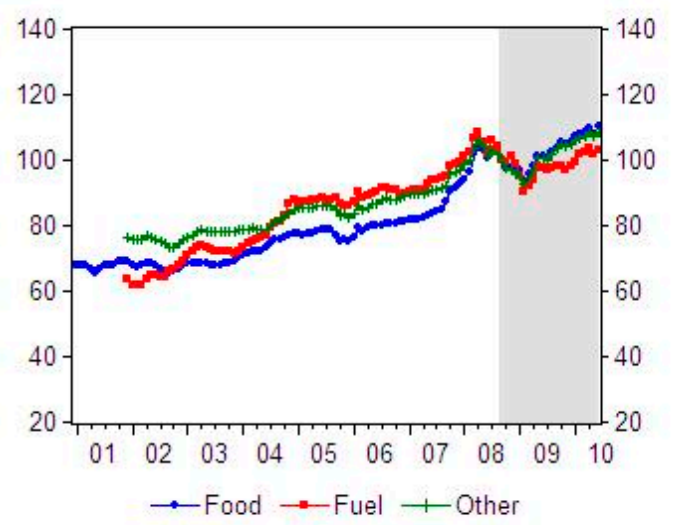


Figure 6. Inflation and Central Banks' Interest Rates in Latin America (Percentage rate)

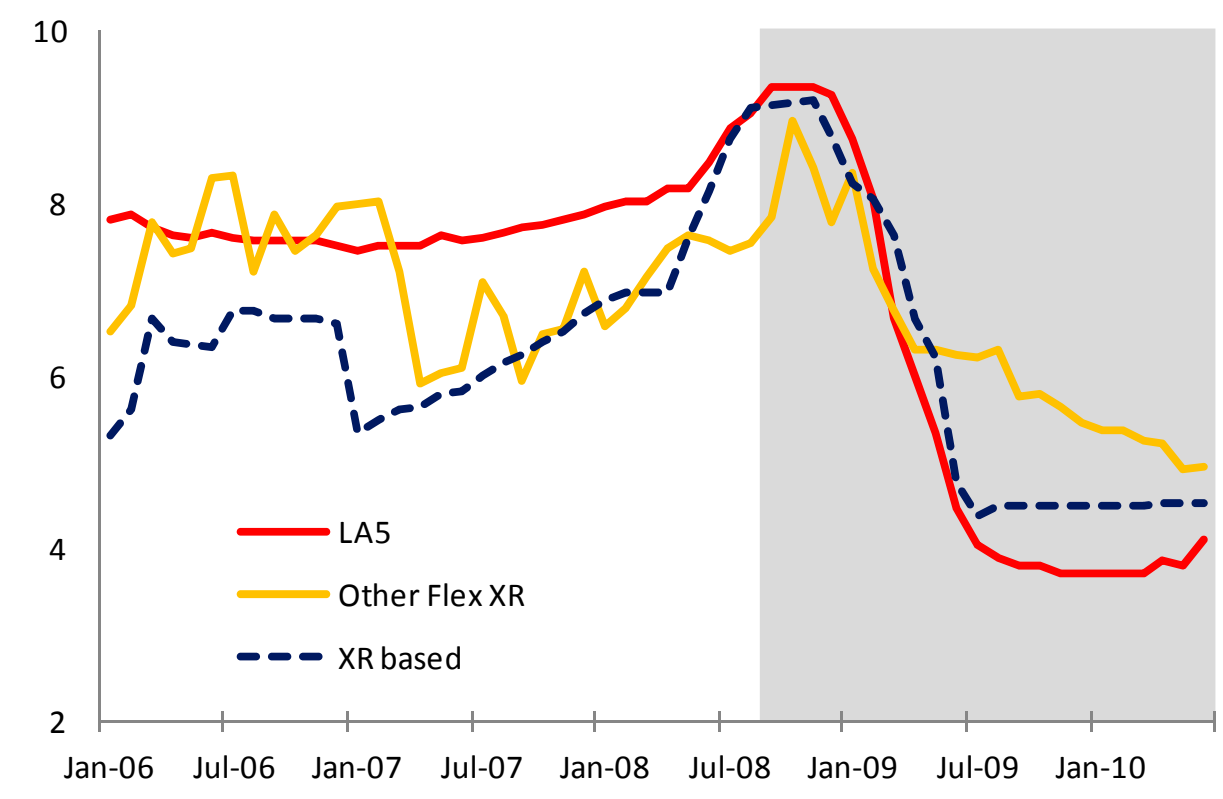

Source: LA5 central banks' websites.

To help contain capital inflows, some LA5 countries introduced capital controls and adjusted reserve requirements. The central bank of Peru raised reserve requirements on both domesticand foreign-currency liabilities, and differentiated, with a much higher reserve requirement coefficient, the deposits of nonresidents denominated in domestic currency. In Colombia, besides raising reserve requirements in domestic currency, the central bank imposed unremunerated reserve requirements (URR) on external borrowing and portfolio inflows. The increases in reserve requirements in domestic currency helped tighten monetary policy and slow down credit growth (Box 2). In Brazil, a presidential decree levied a 1.5 percent tax on capital inflows channeled to investment in fixed-income markets. 
Box 2. Other Measures Aimed at Coping with the Rise in Commodity and Food Prices

\section{Bank of the Republic of Colombia}

The Bank of the Republic (BoR) introduced differentiated marginal reserve requirements on sight and savings deposits (27 percent) and on certificates of deposits (5 percent) in mid-2007. On June 2008, marginal reserve requirements were eliminated and reserve requirements were elevated from 8.3 to 11.5 percent on sight and savings deposits and from 2.5 to 6 percent on certificates of deposits.

In May 2007, the BoR introduced a compulsory unremunerated deposit at the BoR on external borrowing (40 percent at six months) and pre-financing of exports (11 percent at 12 months).

Still in May 2007, the BoR introduced a six months unremunerated deposit of 40 percent on foreign portfolio investments. The deposit rate was increased to 50 percent in May 2008.

\section{Central Bank of Peru}

During 2008, the Central Bank of Peru (BCRP) increased reserve requirements in domestic and foreign currency. In domestic currency, the marginal reserve requirement was increased from 6 percent in January 2008 to 25 percent in April 2008, and, in foreign currency, the marginal rate went up from 30 to 45 percent, for the same period. Also, the minimum reserve requirement rate was augmented to 8.5 percent in April from 6 percent in January, and in April reserve requirements for nonresident financial institutions holdings of domestic currency in the financial system increased to 120 percent.

LA5 central banks reiterated their commitment to price stability and eventually achieved better results than other countries in Latin America. Central banks explained to the markets that raising interest rates was needed because core inflation had started to surge and inflation expectations to diverge from the inflation target tolerance band (in Chile, Colombia, and Peru). Compared to other countries in Latin America and the Caribbean, including the group of officially dollarized countries and others with a currency board in place, the LA5 were able, on average, to better contain inflation pressures (Figure 7). 
Figure 7. Inflation in Latin America and the Caribbean

(Classified by exchange rate regimes. Annual percentage rate)

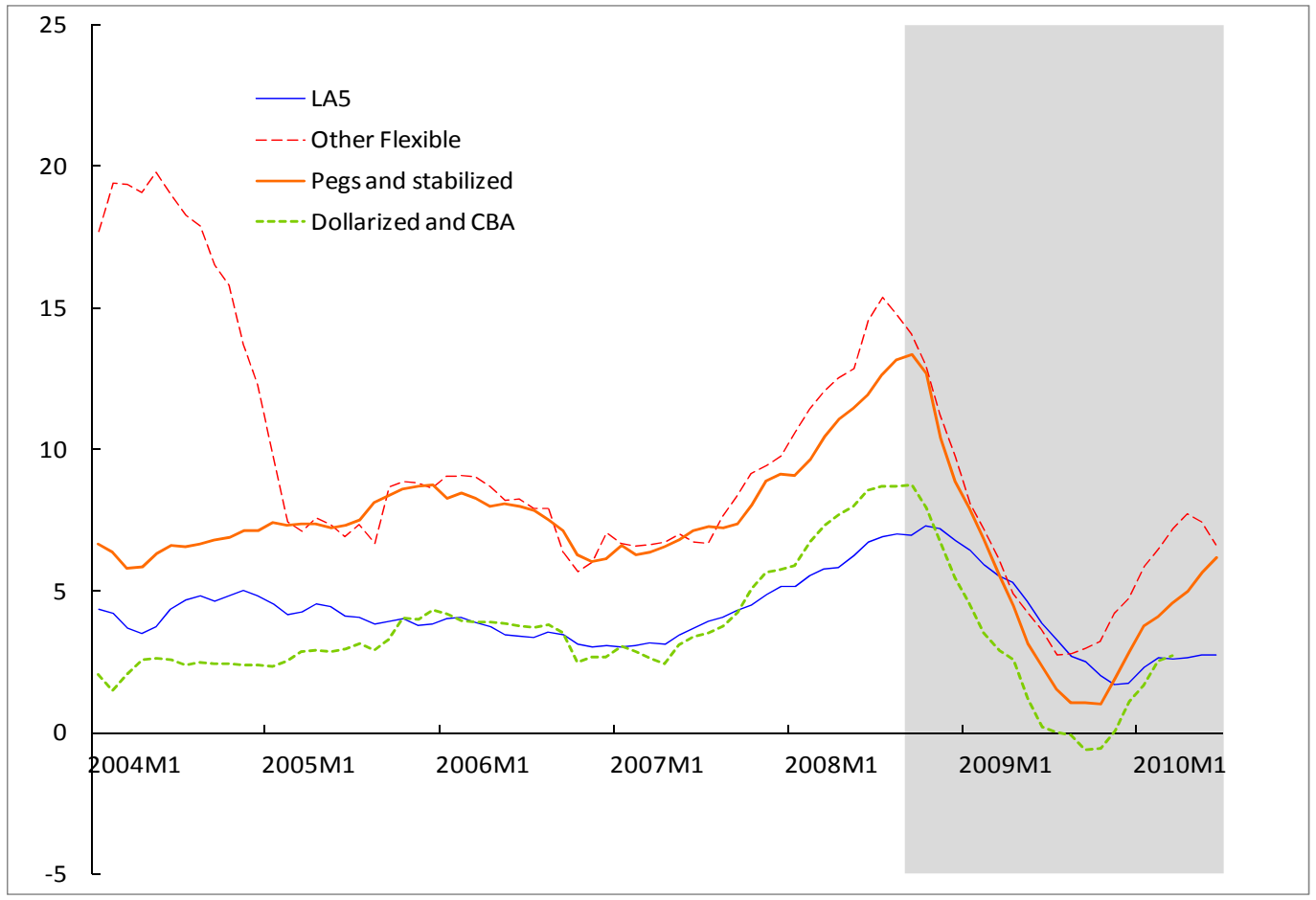

Source: Annual Report on Exchange Arrangements and Exchange Restrictions, IMF.

\section{Dealing with the Global Financial Crisis Following the Lehman Collapse}

The Lehman Brothers' collapse was a turning point toward worldwide disinflation and recession. This financial turmoil had many elements of earlier global financial crises that in the past fueled domestic currency and even banking crises ${ }^{26}$ The old sudden stop and reversal of capital inflows associated with global deleveraging reappeared, leading all domestic currencies to come under pressure, reversing the previous exchange rate appreciation dilemma. The worldwide recession also led exports to tumble throughout the region. For instance, exports declined in the last quarter of 2008 - with respect to the previous quarterby about 20 percent in Brazil and Mexico.

\section{Unconventional Measures to Ease Liquidity}

LA5 central banks responded to the global financial crisis first by providing liquidity in domestic and foreign currency. In contrast to central banks in advanced economies, the LA5 did not reduce policy rates up front and rarely resorted to credit easing or quantitative easing. ${ }^{27}$ Instead, they adopted liquidity easing measures in both domestic and foreign

\footnotetext{
${ }^{26}$ See Jácome (2008).
} 
currencies to alleviate the stress associated to the sudden tightening of external financial conditions, compounded by capital outflows, and reduce the risk of a liquidity crisis. ${ }^{28}$

To provide domestic currency liquidity, most LA5 countries loosened access to central bank facilities for liquidity provision. Central banks broadened collateral (Chile and Mexico) and expanded maturities (Chile and Peru) for repos. Peru also set up foreign exchange swaps to inject liquidity in domestic currency. The Bank of Mexico purchased securities (issued by the Institute for the Protection of Banking Savings), mainly to address liquidity problems in mutual funds.

The central banks in Brazil, Colombia, and Peru also cut reserve requirements. Brazil had ample room to ease reserve requirements given the prevailing high rates - compared to international standards — and used it also to achieve other specific objectives. ${ }^{29}$ Colombia and Peru mostly reversed the increase in reserve requirements adopted in early- and mid2008 after experiencing heavy capital inflows.

Public banks in Brazil, Chile, and Mexico arguably played a countercyclical role. They either increased the growth rate of its credit to the private sector or decreased it at a markedly lower rate than in private banks, especially foreign owned ones. In Brazil, this was explicitly part of the countercyclical policy response of the government to the crisis (Barbosa, 2010). In Chile and Mexico, the markedly contrarian behavior of credit to firms and households from these institutions suggests a similar approach.

Central banks were able to provide FX liquidity for a variety of reasons. First, they were able to build up an international reserve buffer during the period of favorable external financial conditions and terms of trade. Second, they followed good policies that gave them access to the IMF's flexible credit line (Colombia and Mexico), which strongly signaled to the markets the IMF's confidence in their fundamentals and support for their policies. Finally, they had access to a U.S. 30 billion currency swap with the U.S. Federal Reserve Bank (Brazil and Mexico).

To provide FX liquidity, LA5 central banks created mechanisms to lend foreign exchange and reversed earlier measures to contract liquidity. These mechanisms included foreign

\footnotetext{
${ }^{27}$ For definitions of liquidity easing, quantitative easing and credit easing, and a discussion on the different roles unconventional central bank measures played in advanced and emerging economies see Ishi and others (2009).

${ }^{28}$ For example, the central bank of Peru, explains in its website that if the reductions in the reference rate had started before February 2009, they would have run a serious risk that inflation expectations would not have fallen, in addition to the risks of a currency crisis and a credit crunch (see "Medidas monetarias del BCRP frente a la crisis internacional" at http://www.bcrp.gob.pe/politica-monetaria/medidas-monetarias-del-bcrp-frente-a-lacrisis-internacional.html).

${ }^{29}$ For example, in October 2, 2008, the Central Bank of Brazil announced that financial institutions could use up to 40 percent of the reserve requirement on time deposits for purchasing credit loan portfolios of financial institutions with regulatory capital of up to BRL 2.5 billion.
} 
exchange swaps (Brazil and Chile). The Central Bank of Brazil also auctioned collateralized loans to banks to help finance exports and roll over external debts. Peru sold certificates indexed to the U.S. dollar but settled in domestic currency. The extensive use of alternatives to direct dollar spot sales helped preserve international reserves. To help foreign exchange liquidity easing, Brazil, Colombia and Peru also relaxed the measures affecting investments by nonresidents that had been imposed in 2007 and in the first half of 2008. In addition, Peru cut reserve requirements for dollar deposits, and Chile allowed the use of pesos to fulfill reserve requirements on dollar deposits. Some LA5 central banks also adopted new mechanisms for providing hedge against the depreciation of domestic currencies, including through derivatives (Appendix 4).

These liquidity easing measures expanded central banks' balance sheets. Although central banks' balance sheets grew in LA5 countries due to these measures, the increases were not as large as in industrial countries (except Japan), in particular, the United States and the United Kingdom (Figure 8$){ }^{30}$

Figure 8. Central Bank Assets in LA5 and Selected Industrial Countries (Index numbers. January $2006=100$ )
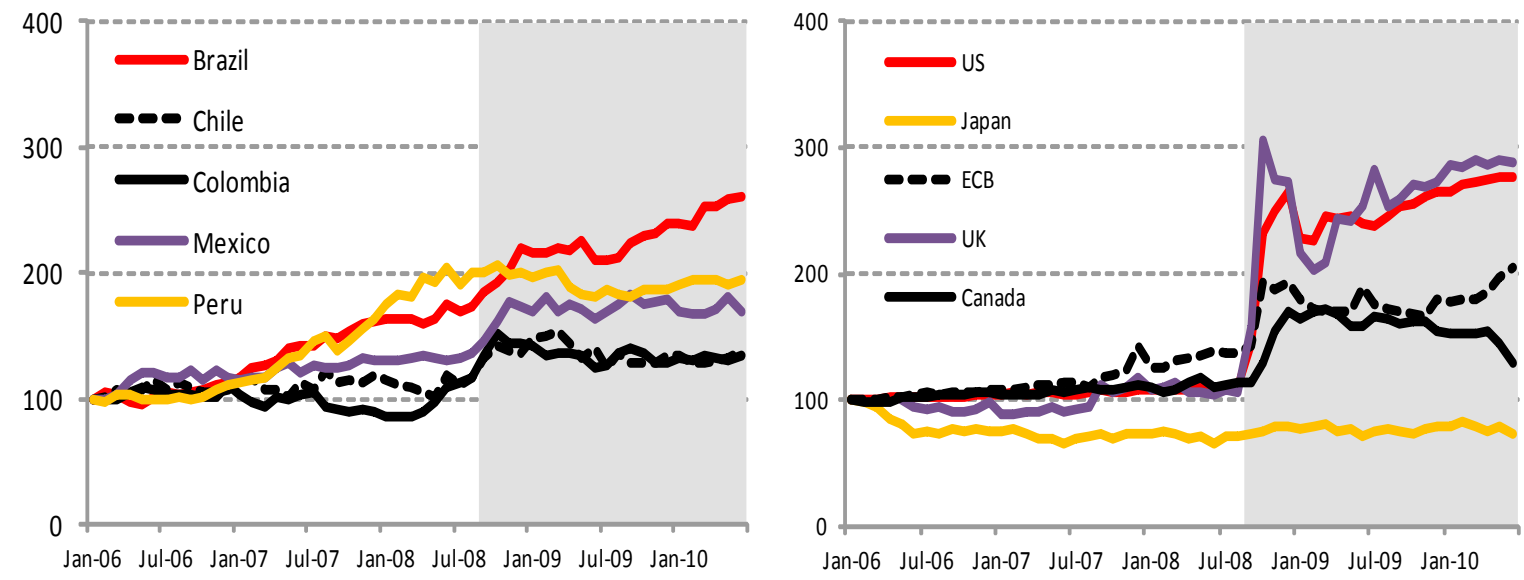

Source: International Financial Statistics for LA5 countries and central bank websites for industrial countries.

\section{Exchange Rate Response}

Foreign exchange markets were the first to dry up as the financial turmoil acquired a global dimension in September 2008. This triggered immediate responses in all LA5 countries, aiming to safeguard the economy from the consequences of excessively sharp swings in the exchange rate and in the cost of external financing.

Domestic currencies were allowed to depreciate as capital inflows started to revert. Brazil and Mexico endured the largest currency depreciation — about 30 percent between August

\footnotetext{
${ }^{30}$ For a review of the unconventional monetary policies in advanced economies, see Borio and Disyatat, 2009.
} 
2008 and February 2009. The Central Bank of Peru only allowed its currency to depreciate by 11 percent. Despite large depreciations, inflation not only remained in check, but also kept falling in all LA5 countries. This partly reflected the worldwide recession and associated decline in inflation around the globe, but also a drastic decline - associated with increased monetary policy credibility - in the pass-through from currency depreciations to inflation.

Yet, some central banks sold significant amounts of foreign exchange (Figure 9). The central bank of Peru sold close to 20 percent of its international reserves over a couple pf months, to smooth out the depreciation trend in an environment of still high financial dollarization. Brazil and Mexico sold almost 10 percent of the international reserves on their books over a couple of months. In these two countries, concerns about large corporations having short dollar positions added to the motivation for avoiding a sudden and severe devaluation of the domestic currency. The Bank of Mexico used three main channels for its sales of foreign exchange: extraordinary auctions in October 2008 (roughly 35 percent of total sales), daily auctions with and without a minimum price ( 60 percent), and direct sales ( 5 percent). The Central Bank of Brazil employed non-deliverable currency swaps to supplement direct intervention in the spot foreign exchange market. ${ }^{31}$ Chile and Colombia followed a different path since they placed the burden of the adjustment on the exchange rate and, therefore, sold few international reserves (although Chile made use of its large fiscal funds abroad). Chile stopped buying dollars, which had amounted to US\$50 million, daily, since April 2008. Colombia also stopped daily foreign exchange interventions to build international reserves in October 2008, and at the same time reactivated a mechanism of auctioning volatilitytriggered options that led to sales of foreign currency as the peso depreciated..$^{32}$ Despite the large exchange rate movements, inflation remained remarkably stable, suggesting that the monetary frameworks had provided a nominal anchor and reduced the exchange rate passthrough (Figure 10).

\footnotetext{
${ }^{31}$ See Stone and others, 2009.

${ }^{32}$ The mechanism for auctioning options had been suspended in June 2008. After being reactivated in October 2008, it was suspended again in October 2009.
} 
Figure 9. LA5 external adjustment after Lehman's collapse

(International reserves (dots) and exchange rates (lines). (Index numbers))
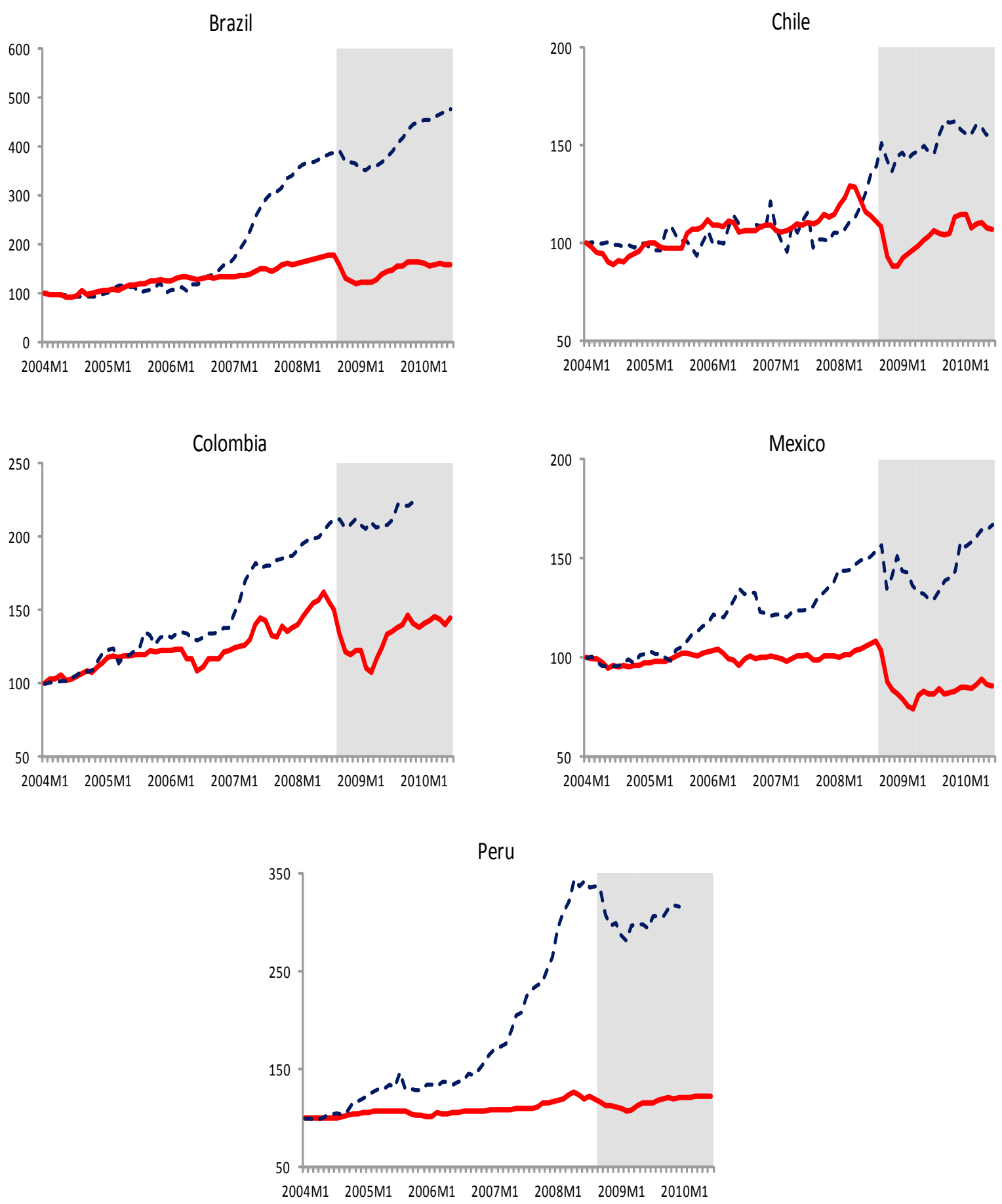

Source: International reserves (IFS, row 1L), exchange rate index (Insdata, edna). 
Figure 10. Exchange Rate Pass-through, Consumer Price Inflation and Currency Depreciation (Percent change, 12 months)
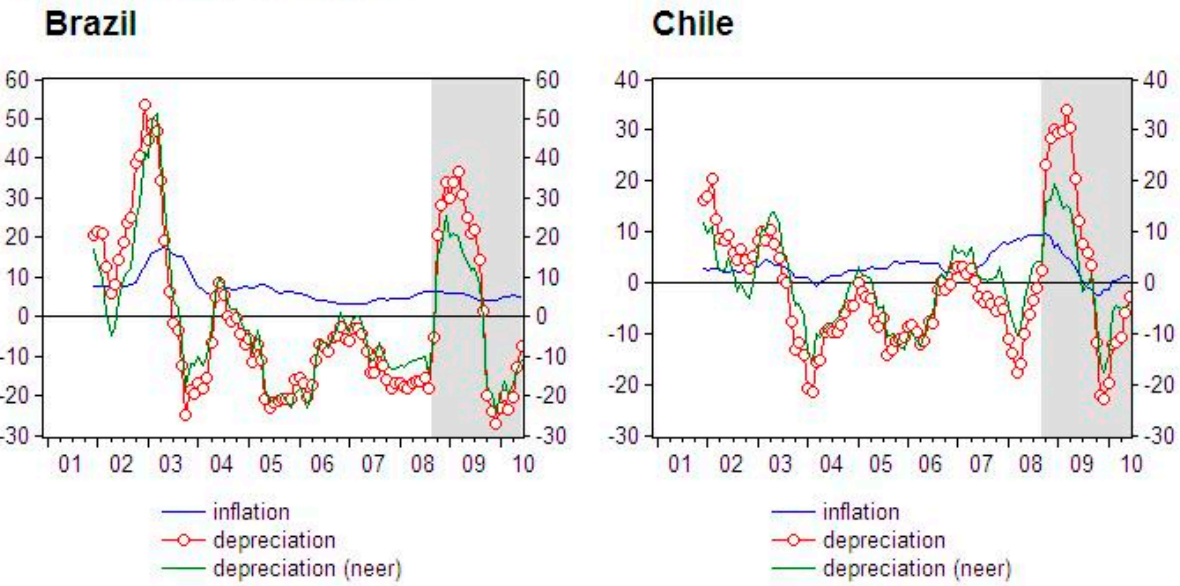

Colombia

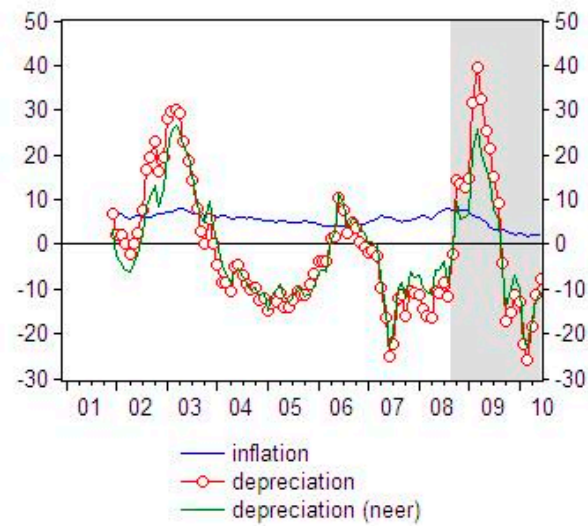

\section{Peru}

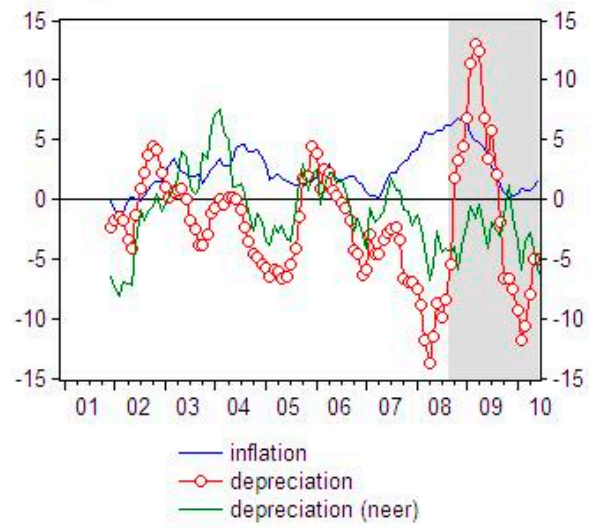

Mexico

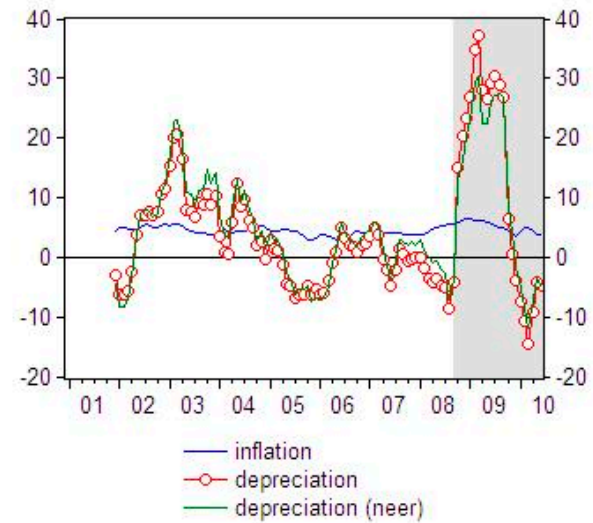




\section{Changes to the policy rate}

By early 2009, LA5 central banks started to cut policy rates. The pace of monetary policy loosening varied in each country, depending on inflation projections and each country's position in the business cycle (Figure 2 and Table 6). The Central Bank of Chile was the most aggressive, slashing its policy rate by 600 basis points during January-March and 775 basis points up to July 2009. In addition, it set up a term liquidity facility to reinforce its commitment to keep the policy rate low for long. ${ }^{33}$ At the other end, the Bank of Mexico followed a more conservative approach, because inflation and inflation expectations remained high. The Central Bank of Peru reacted with a short lag reducing its policy rate only 50 basis points in the first quarter, given a slower decline in inflation expectations. ${ }^{34}$

Because policy rates were high before the Lehman event, most LA5 central banks could cut them significantly. In contrast, central banks in the industrial world - where policy rates were already close to the zero bound — did not have this alternative. Most LA5 central banks did not get close to the zero bound. The Central Bank of Brazil stopped reducing the policy rate by July 2009 at 8.75 percent -4 percent in real terms when deflated by the contemporaneous inflation. The Central Bank of Chile was the only one in the LA5 to cut the policy rate to close to zero (0.5 percent), in July 2009.

Table 6. Policy Rate Cuts by LA5 Central Banks in 2009

(Basis points)

\begin{tabular}{lcccccc}
\hline & End-2008 & 2009-Q1 & 2009-Q2 & 2009-Q3 & 2009-Q4 & End-2009 \\
\hline Brazil & $13.75 \%$ & 250 & 200 & 50 & 0 & $8.75 \%$ \\
Chile & $8.25 \%$ & 600 & 150 & 25 & 0 & $0.50 \%$ \\
Colombia & $9.50 \%$ & 250 & 250 & 50 & 50 & $3.50 \%$ \\
Mexico & $8.25 \%$ & 150 & 200 & 25 & 0 & $4.50 \%$ \\
Peru & $6.50 \%$ & 50 & 300 & 175 & 0 & $1.25 \%$ \\
\hline
\end{tabular}

Source: LA5 central banks' websites

Money growth, which is endogenous under inflation targeting, initially fell significantly around the Lehman events (Figure 11). The slowdown in economic activity reduced money demand, which contributed to the deceleration in money growth that, in many countries, had started earlier. As uncertainty subsided and economic activity started to recover, the low policy interest rates led to a recovery in money growth in the region, but the pace was not even across countries. As the recovery took hold, credit growth has started to pick up again (Figure 12).

\footnotetext{
${ }^{33}$ Through the FLAP (Facilidad de Liquidez a Plazo), "banking firms could access liquidity at 90 and 180 days at the prevailing MPR" (Central Bank of Chile, "Monetary Policy Report", December 2009).

${ }^{34}$ Fiscal measures complemented the central bank's countercyclical efforts (IMF, 2009).
} 
Figure 11. Consumer Prices and Money Growth (Percent change, 12 months)

\section{Brazil}

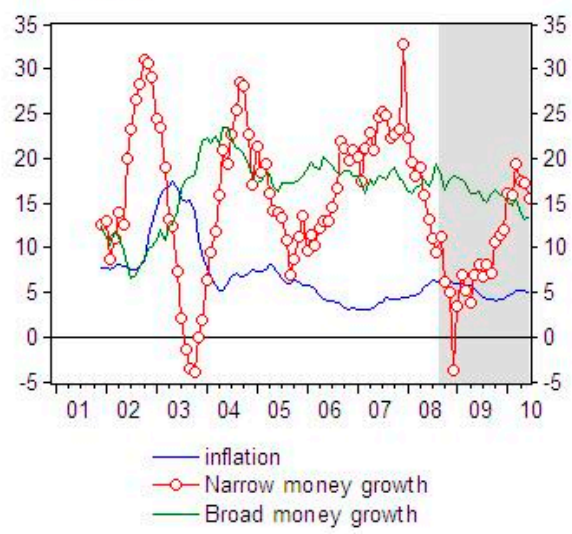

Colombia

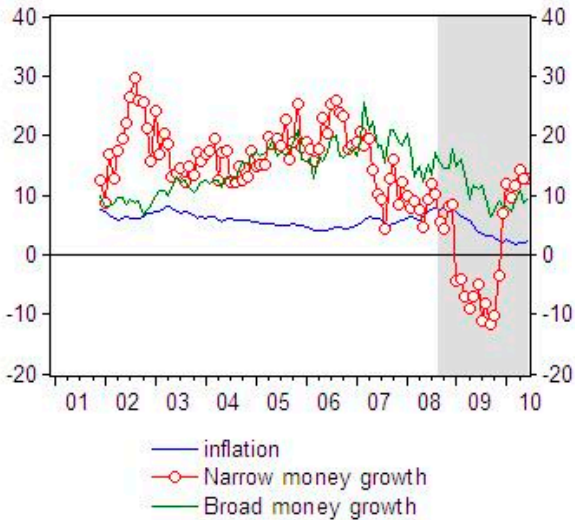

Peru

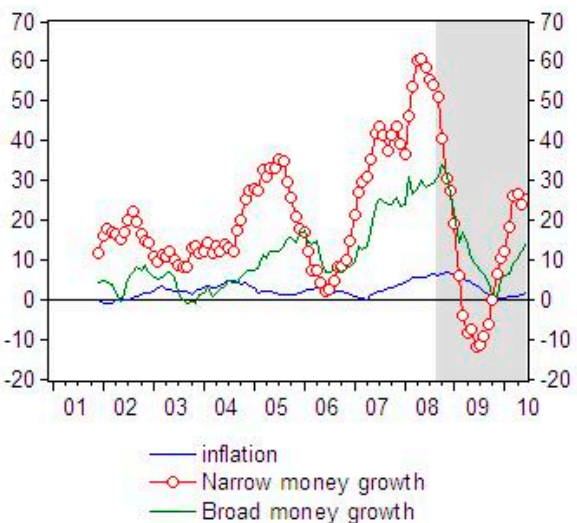

Chile

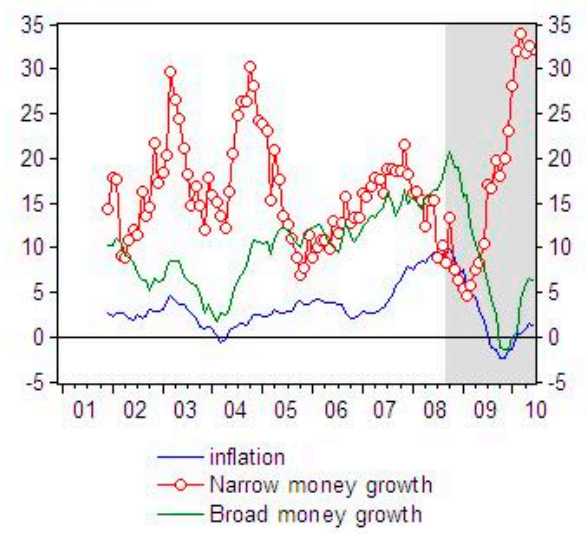

Mexico

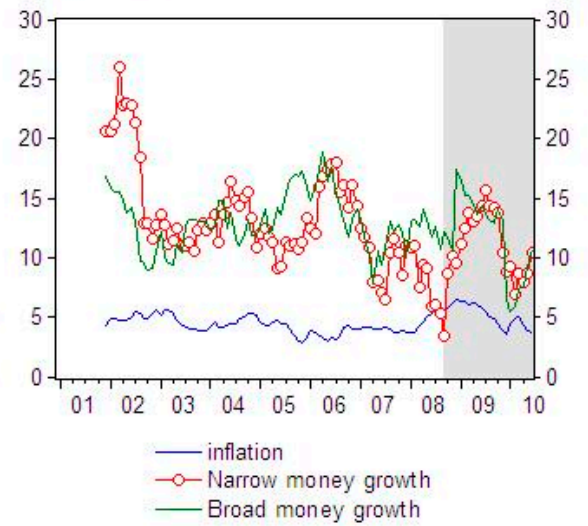


Figure 12. Monetary Developments and Private Credit Growth (Percent change, 12 months)

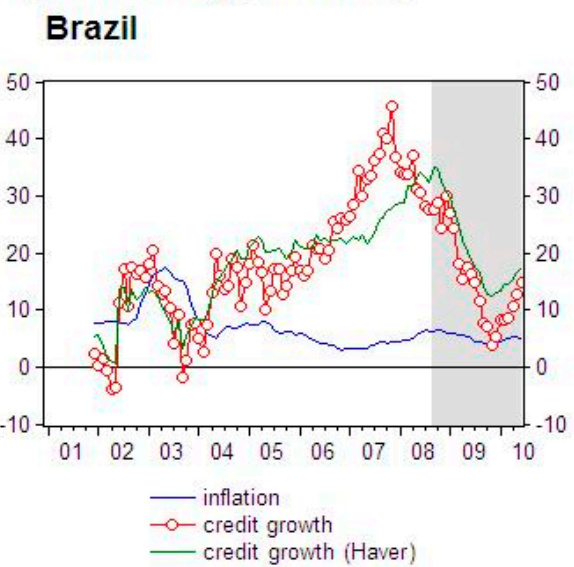

\section{Chile}
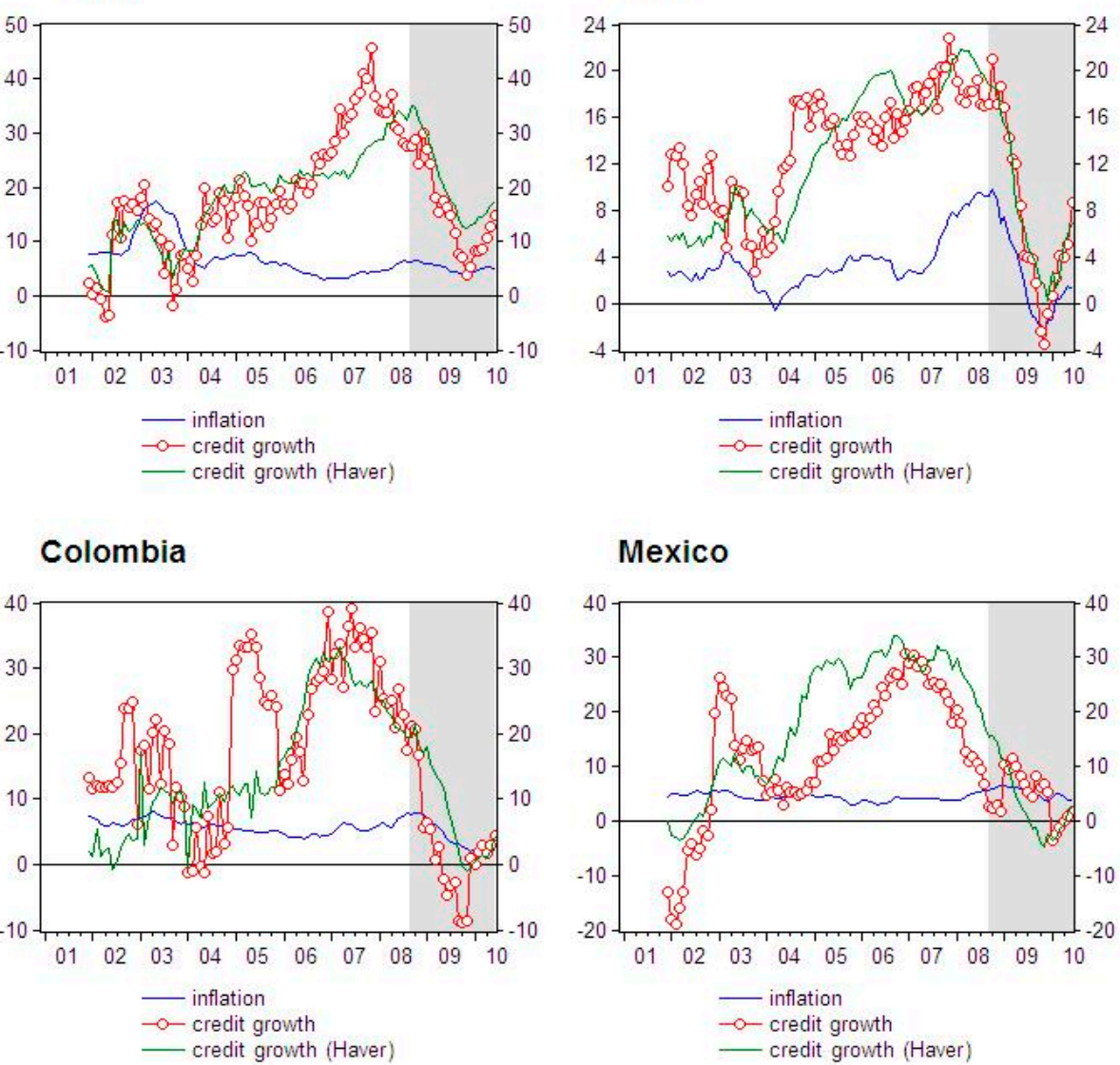

Mexico

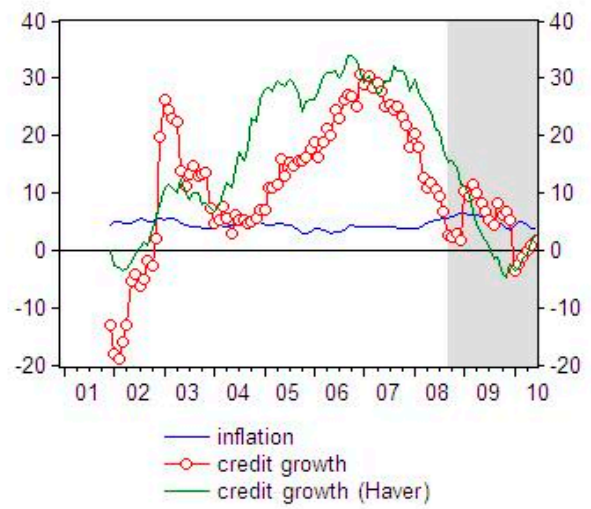

\section{Peru}

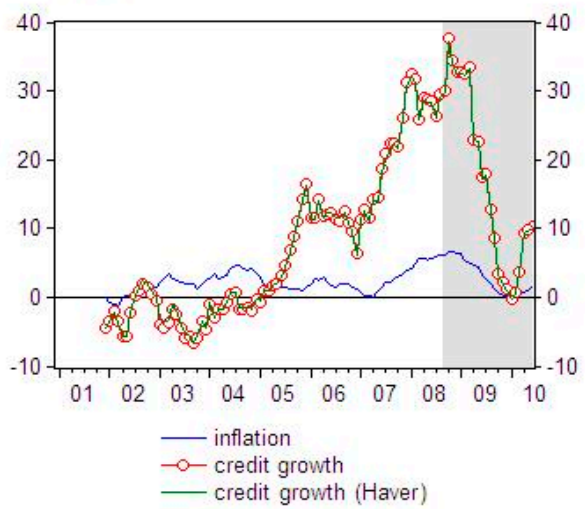




\section{Box 3. Panel Vector Autoregression}

For each country $i$, the panel estimates

$\boldsymbol{x}_{i t}=\boldsymbol{\alpha}+\boldsymbol{\beta} \boldsymbol{x}_{i t-1}+\boldsymbol{u}_{t}$

$\boldsymbol{x}_{i t}=\left[\begin{array}{c}G R O W T H_{-} U S_{t} \\ R R_{-} U S_{t} \\ D(L Z)_{i t} \\ Y_{i t} \\ \text { PIE } 4 S_{i t}\end{array}\right], \boldsymbol{\alpha}=\left[\begin{array}{c}\alpha^{1} \\ \alpha^{2} \\ \alpha^{3} \\ \alpha^{4} \\ \alpha^{5} \\ \alpha^{6}\end{array}\right], \boldsymbol{\beta}=\left[\begin{array}{ccc}\beta^{16} & \ldots & \beta^{16} \\ \cdot & & \cdot \\ \cdot & & \cdot \\ \cdot & & \cdot \\ \beta^{61} & \ldots & \beta^{66}\end{array}\right], \boldsymbol{u}_{t}=\left[\begin{array}{c}u_{t}^{1} \\ u_{t}^{2} \\ u_{t}^{3} \\ u_{t}^{4} \\ u_{t}^{5} \\ u_{t}^{6}\end{array}\right]$,

where, for every period t, GROWTH_US $S_{t}$ is the quarterly U.S. GDP growth seasonally adjusted, $R R_{-} U S_{t}$ is the U.S. Fed Funds rate, $D(L Z)_{i t}$ is the changes in the exchange rate against the U.S. dollar in country $i, Y_{i t}$ is the output gap computed for country $i$, computed as a latent variable in a country-version of the Global Projection Model (see Carabenciov and others (2008), and Canales-Kriljenko and others (2008), PIE4 PIET AR $_{i t}$ is the moving average (4) quarterly inflation in country $i$ less the inflation target range, and $R S_{i t}$ is the monetary policy rate in country $i$.

Letting $i$ equal to $1 \ldots 5$, the equation system (1) is stacked for the 5 LA5 countries. The model is estimated using quarterly data for the period of 2002-09, which covers the recent international crises but excludes episodes of individual country crises that occurred prior to 2002. We use the inverse of the Cholesky factor of the residual covariance matrix with a small sample degrees of freedom correction to orthogonalize the impulse responses. In the Cholesky ordering we follow the same sequencing as presented in $\boldsymbol{x}_{i t}$ with $y_{i t}^{U S}$ as the most exogenous variable and $i_{i t}$ as the most endogenous.

Empirical analysis shows that LA5 policy rates have systematically reacted to changes in the economic environment. This systematic response to key macroeconomic variables during 2002-09 is summarized by a simple panel vector autoregression (Box 3). The impulse responses suggest what one would expect from a well-functioning flexible monetary policy. On average, policy rates have increased (fallen) when inflation exceeded (was less than) its target and GDP was above (below) its potential level (Figure 13). Simple scatter plots between policy interest rates and inflation and GDP growth reinforce the message (Figures 14 and 15). The impulse responses also suggest that at least some policy interest rates have responded to innovations in the exchange rate, which could reflect concerns about the passthrough onto inflation or economic disruptions associated with balance sheet exposures. ${ }^{35}$ The analysis also revealed a systematic response to growth in the U.S., which probably reflects the influence of the U.S. on LA5 economic activity, especially in Mexico. These

\footnotetext{
${ }^{35}$ The impulse response differs from the usual Taylor rule that identifies parameters that measure the reaction of policy interest rates to the inflation and output gaps. Instead, it summarizes the joint effect of the policy response and the transmission mechanism. Thus, even if the authority does not respond directly to exchange rates, the impulse response would still show a reaction to innovations in the exchange rate if they affected variables the authority cared about, including the inflation and output gaps.
} 
impulse responses show that the policy rate responses have been systematic, but they do not identify a policy reaction function, which is beyond the scope of this paper. ${ }^{36}$

\section{Figure 13. LA5—Policy Reaction Functions ${ }^{1 /}$ (2002:Q1-2009:Q4)}
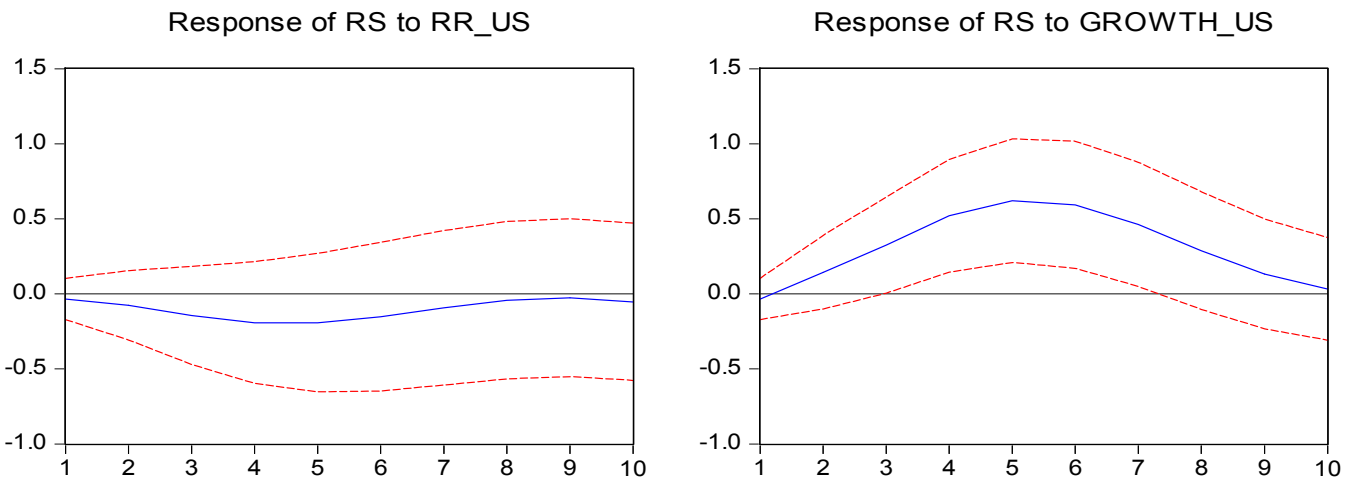

Response of RS to $\mathrm{D}(\mathrm{LZ})$

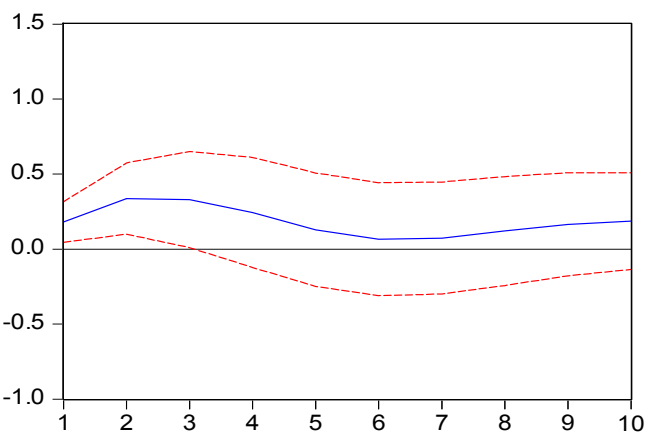

Response of RS to PIE4-PIETAR

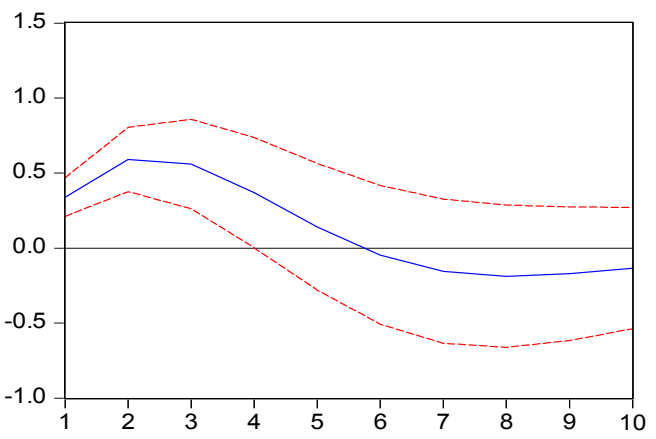

Response of RS to $Y$

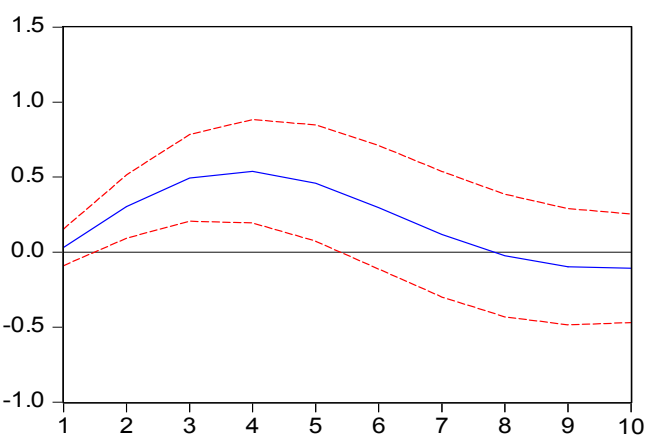

Response of RS to RS

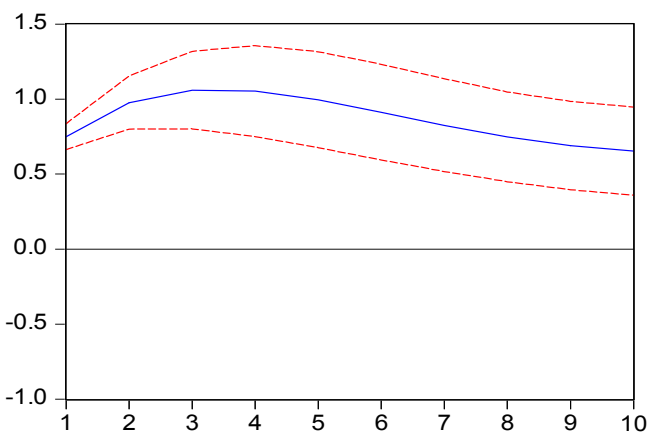

Source: Fund staff estimations.

1/ Panel response of policy rate (RS) to Cholesky, one standard deviation +/- 2 standard errors of the following variables: US Federal Funds Rate (RR_US), US GDP growth (GROWTH_US), changes in nominal exchange rate (D(LZ)), deviations of inflation from target (PIE4-PIETAR), output gap (Y), and lags policy rate.

\footnotetext{
${ }^{36}$ A careful description of the structure of the economy is convenient to attempt such estimation, although some authors have avoided this description by using econometric methods that rely on instruments (Leiderman, Maino, and Parrado, 2006). See also Cowan and others, 2009.
} 
Figure 14. LA5—Policy Rates and Inflation, 2005-2009
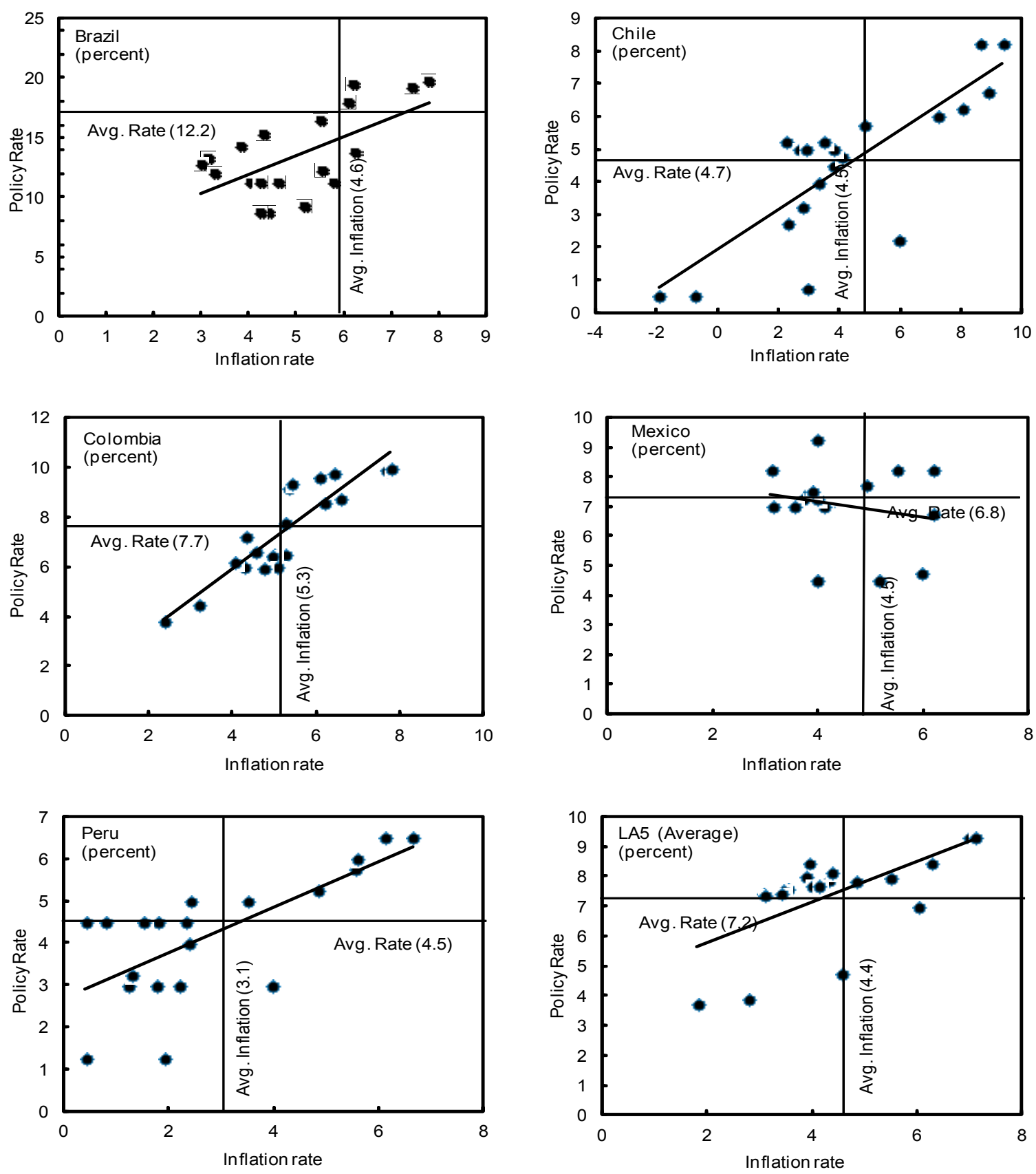

Source: National authorities and Fund staff calculations. 
Figure 15. LA5—Policy Rates and GDP Growth (2005-2009)
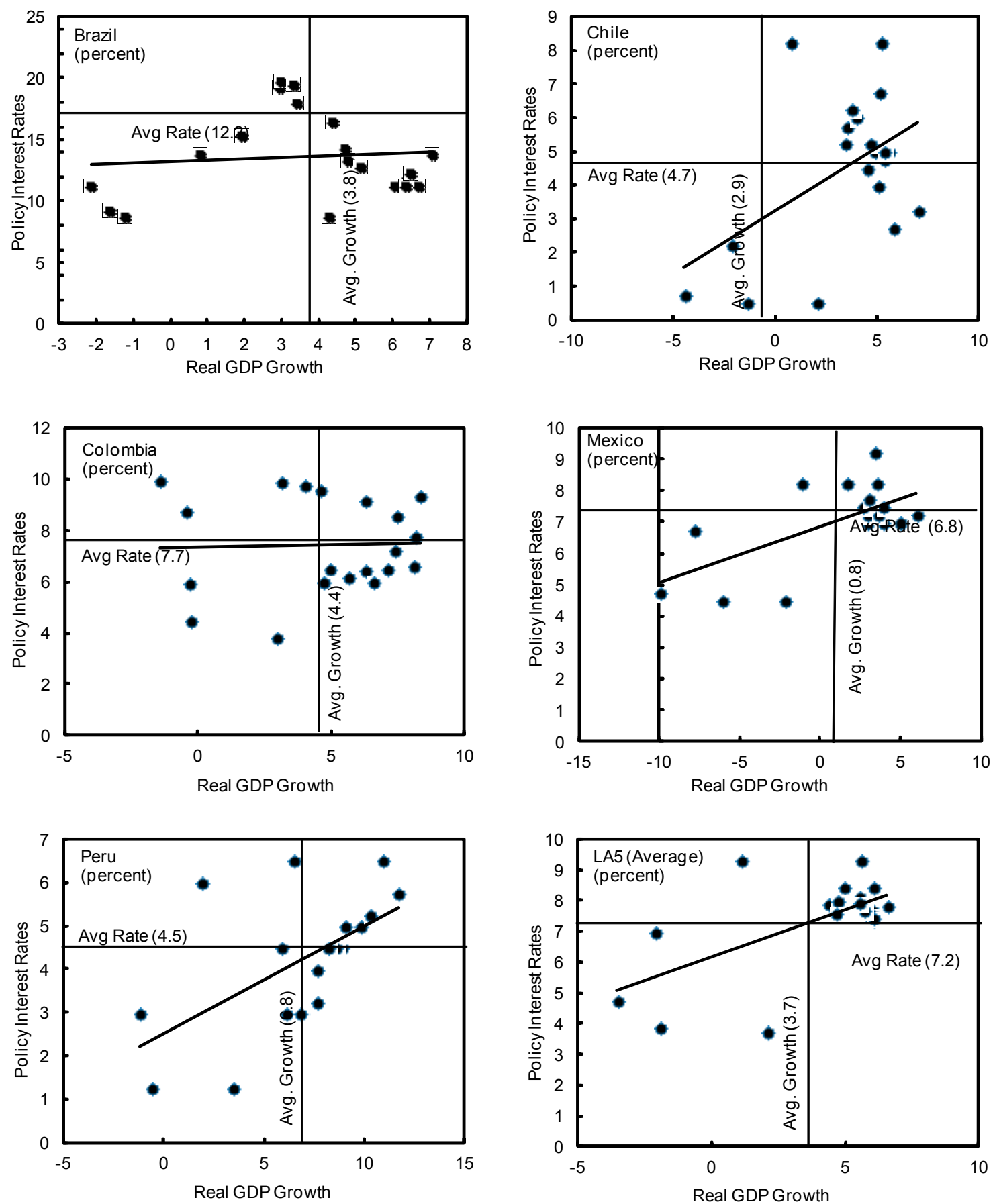

Source: National authorities and Fund staff calculations. 


\section{Central bank communication}

Central banks clearly explained to the markets their policy decisions and goals. They stressed that prospects for low inflation and economic recession warranted an unusually aggressive cut of policy rates. They noted that expansionary monetary policies were needed to preserve normal liquidity conditions - an implicit reference to financial stability. Similarly, they argued that selling foreign exchange in the market was necessary for several reasons. In Brazil, Mexico, and Peru, it was needed to secure liquidity conditions in foreign currency. In Peru, it also helped avoid adverse balance sheet effects. Finally, in Brazil and Mexico, the central bank foreign exchange operations made their way to corporations that had previously engaged in uncovered derivative transactions. Nevertheless, while explaining their decisions to ease monetary policy and ensure financial market functioning, LA5 central banks clearly delivered the message that monetary policy tightening would start as soon as inflation pressures emerged.

In addition to the regular publications and announcements, LA5 central banks explained their unconventional liquidity easing measures. The Central Bank of Brazil issued a press release each day that a measure was taken. ${ }^{37}$ In Mexico, the central bank published a note on the official measures taken to preserve financial stability, part of which was reproduced in the July-September 2008 inflation report. ${ }^{38}$ The Central Bank of Chile published, in November 2008, an update of the recent projection scenario rather than waiting until for the next monetary policy report. ${ }^{39}$ The Central Bank of Peru explained in its website the measures it took to face the international crisis. ${ }^{40}$

\footnotetext{
${ }^{37}$ See, for example, http://www.bcb.gov.br/noticias/VisualizacaoNoticia.aspx?cod=1852, http://www.bcb.gov.br/noticias/VisualizacaoNoticia.aspx?cod=1856, http://www.bcb.gov.br/noticias/VisualizacaoNoticia.aspx?cod=1872, and http://www.bcb.gov.br/noticias/VisualizacaoNoticia.aspx?cod=1890, or browse the press releases starting at $\mathrm{http} / /$ www.bcb.gov.br/noticias/Noticias.asp?noticia=1\&idioma=P

38 "Medidas Instrumentadas por el Gobierno Federal y el Banco de México para Preservar la Estabilidad Financiera", electronically available at (http://www.banxico.org.mx/material-educativo/index.html).

${ }^{39} \mathrm{http} / / /$ www.bcentral.cl/eng/publications/policies/pdf/update112008.pdf

${ }^{40} \mathrm{http}: / / \mathrm{www}$. bcrp.gob.pe/politica-monetaria/medidas-monetarias-del-bcrp-frente-a-la-crisis-internacional.html
} 
Figure 16. LA5 Inflation Rates and Inflation Expectations (Annual percentage rate)
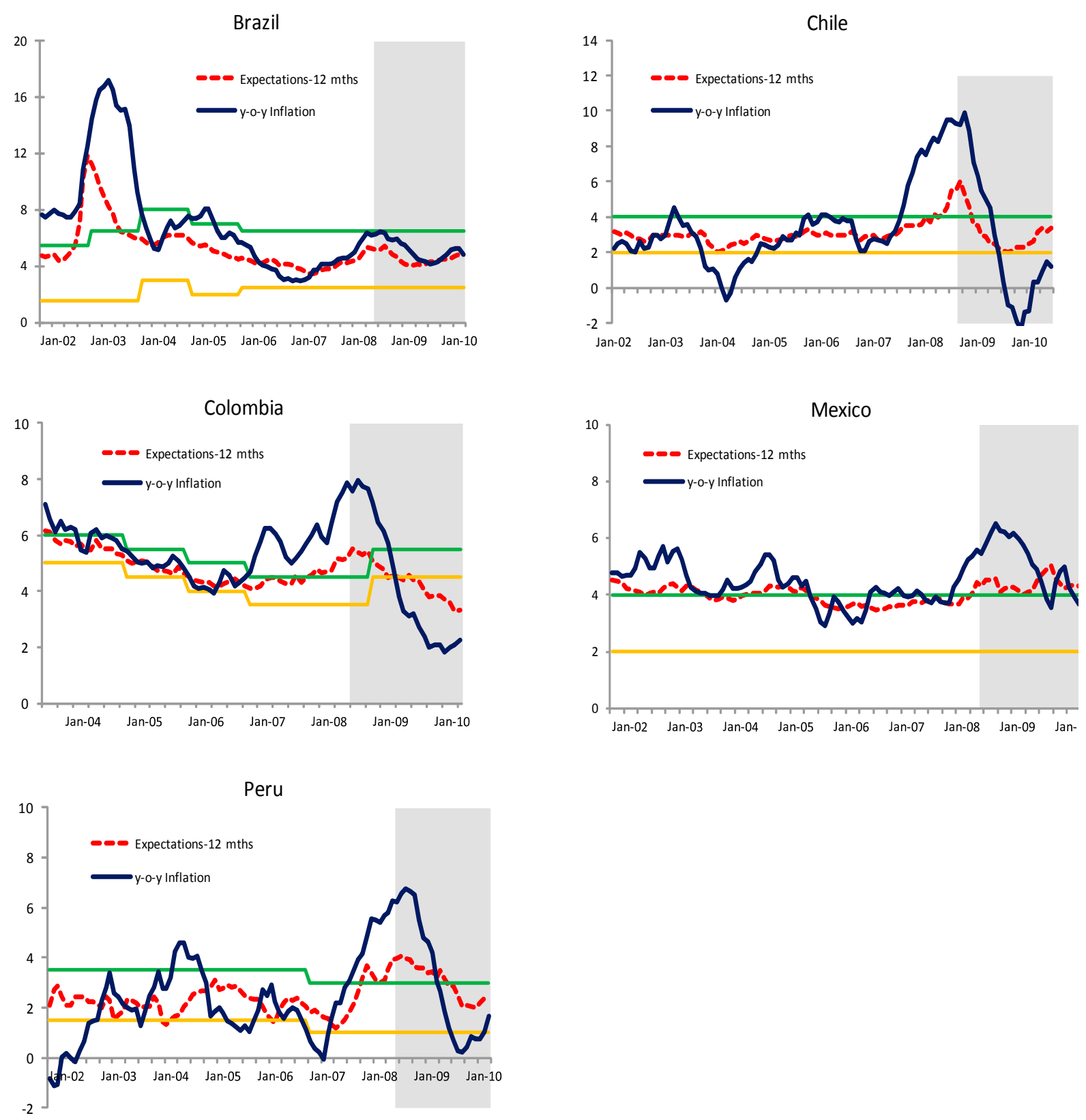

Source: LA5 central bank websites.

\section{Relative Inflation Performance of Flexible Frameworks}

The LA5 central banks have successfully passed the tests posed by high commodity and fuel prices, capital outflows, and a global recession. They have allowed the exchange rate to move, while keeping inflation expectations well anchored around their target levels. In particular, 12-month inflation expectations have evolved within the inflation targeting band during most of the period of analysis in all LA5 central banks, even when contemporaneous 
inflation missed the target band (Figure 16). For instance, during periods of worldwide inflation (2007-2008), inflation expectations were lower than current inflation. This suggests that central banks' credibility led markets to distinguish between cyclical pattern of shortterm inflation and long-run trends, keeping inflation expectations anchored in the long run. Inflation expectations remained well anchored despite sharp movements in the nominal exchange rate, suggesting that the pass-through has fallen significantly compared to previous crises.

Although most Latin American countries were able to keep inflation relatively low, inflation volatility was significantly lower in the LA5 countries (Figure 7). Countries with less flexible exchange rate regimes depended more on external developments, which were unfavorable during this global financial crisis. They received more capital flows and faced a more volatile domestic demand (Canales-Kriljenko, forthcoming, and IMF, 2010). ${ }^{41}$

\section{Suggestions For EnHANCING CREDIBILITY AND MOVING TOWARD INCREASED Monetary Policy FleXibiLity}

For central banks interested in enhancing credibility and increasing the flexibility of their monetary frameworks, as the LA5 countries did over the last two decades, the following suggestions could help them find their own path. We have put them together based on the experience of the five countries in Latin America reviewed earlier, and complemented with recommendations established in the literature and IMF experience with technical assistance and surveillance.

\section{Enhancing Autonomy and Accountability of the Central Bank}

Central banks need to have the autonomy to carry out their mandate and resist political and interest-party pressures. Autonomy granted by law can go a long way in resisting those pressures. Key legal provisions consist on vesting central bank with the power to autonomously manage the policy interest rate and forbidding or limiting direct lending to the government. ${ }^{42}$ Adequate central bank capitalization could also help with financial autonomy,

\footnotetext{
${ }^{41}$ Despite being vulnerable to financial crises, countries with fixed exchange rate regimes have also been able to keep inflation in check. The fixed exchange rate has been a credible anchor for keeping inflationary expectations in check in some economies. Many of the 34 countries in the Latin America and Caribbean region, especially the small islands, still rely on monetary frameworks anchored on the exchange rate to the U.S. dollar. These include countries with a strong commitment to this regime, namely those in the Eastern Caribbean Currency Union and those that have directly adopted the U.S. dollar as legal tender (Ecuador, El Salvador, and Panama). In turn, the inflation experience with intermediate regimes has been mixed. Although some still have difficulty controlling inflation and inflation expectations given the lack of a credible nominal anchor, many countries in this group have also been able to preserve stability. Although inflation has remained relatively stable, these countries may have lost opportunities to better smooth disruptions in their economies arising from external shocks.

${ }^{42}$ For specific recommendations on restricting central bank financing to the government see Jácome and others, 2010.
} 
strengthening monetary policy credibility. ${ }^{43}$ While many countries worldwide have already taken steps in the direction of strengthening central banks' autonomy, in a number of cases this has not been observed in practice. As the experience in Latin America shows, consolidating autonomy and independence could take long and depend on how strong is the political support to an effective autonomy - in addition to the legal changes. To increase the chances of gathering this political support, central banks should be held legally accountable in return of the enhanced delegated authority they received. While no "best practices" exist for accountability procedures - except for appearances of central bank authorities before Congress to report on the observance of their policy targets - , conventional wisdom emphasizes enhancing central banks' transparency.

\section{Enhancing Communication Strategies and Transparency}

Better communication and transparency are critical to boost the effectiveness of monetary policy and to enhance its credibility. Moreover, they are particularly welcome to support flexible policy regimes, like inflation targeting. The effectiveness of these policy regimes can benefit if firms, households, and financial institutions trust that monetary policy authorities will behave according to their policy objectives. This trust can be nurtured when market participants can also verify for themselves, at a reasonably low cost, that the monetary policy authorities are acting consistently with their stated objectives. Maintaining policy consistency involves providing as much information about central bank policy as possible, without risking or damaging its negotiating ability in the market. ${ }^{44}$

\section{Adopting an Appropriate Monetary Policy Regime and Adapting to it}

The experience of the LA5 countries suggests that IT has proved to be an effective policy regime, but there is a tradeoff between simplicity and flexibility in alternative monetary policy regimes. Simple frameworks - like an exchange rate anchor - are easier to manage, but more complex frameworks can deliver more flexibility that could lessen output costs from adverse shocks. ${ }^{45}$ For example, flexible exchange rates could help shield the domestic economy from external shocks that need a real depreciation. Nominal currency depreciation would avoid the need of a fall in the price level, which under nominal rigidities could aggravate a recession. In contrast, under a fixed exchange rate regime or a conventional peg,

\footnotetext{
${ }^{43}$ See Stella, 2005.

${ }^{44}$ A few examples may be illustrative. More transparency and credibility could be achieved if an institution, which is independent of the monetary authority produces the data on inflation and GDP. In addition, transparency could be improved by conducting periodic surveys on inflation and economic activity expectations, which could be made available to the public and contrasted to the central bank forecasts and targets.

${ }^{45}$ Many central banks in less developed countries, working under a money targeting regime may also want to increase the flexibility of their framework. These central banks often still conduct monetary policy using the traditional financial programming toolkit. However, they may want to shift to a more flexible monetary framework, like for example IT, when controlling money base — or other monetary aggregate — becomes increasingly difficult or the association between money and inflation becomes unstable.
} 
the same shocks may lead to a sharper domestic adjustment if interest rates must rise to defend the exchange rate. More flexible regimes, however, are more costly to adopt and manage. For some of the smaller economies, these fixed costs may tilt the balance toward simpler frameworks, even if they would benefit from a more flexible monetary framework. Although LA5 countries have benefited from the flexibility of IT, different countries should choose their regimes based on their specific circumstances.

Authorities who choose increased nominal flexibility need to set proper incentives and mechanisms for managing the risks associated with it. These incentives should minimize potential disruptions arising from the increased nominal volatility. This is important in countries with little experience managing exchange rate risk moving toward higher exchange rate flexibility. ${ }^{46}$ Moving from a fully fixed exchange rate environment toward a flexible one is more successful if countries do it gradually and take some precautions. In particular, countries should preserve a nominal anchor during the transition to keep inflation expectations in check. It is also crucial to redefine prudential rules to encourage private entities to take exchange rate risk prudently, especially private financial institutions that benefit from safety nets. These mechanisms may include rules on net open foreign exchange positions, setting aside capital for exchange rate risk, considering stress tests for exchange rate positions or value at risk exposures, among others. Among the mechanisms for managing exchange risks, authorities could help develop and regulate markets for that purpose, including forward and futures markets.

Further institutional changes are often needed. Three areas are worth highlighting. First, the central bank may need to be reorganized. This may include changing the central bank law as most LA5 countries did, restructuring the central bank (like in Brazil and specially in Peru), and developing operational expertise in new areas. ${ }^{47}$ Second, changes to the prevailing monetary policy framework can affect significantly the way the economy reacts to adverse shocks. Thus, the monetary authority may need to improve methods and techniques to better understand how monetary policy decisions interact with economic developments. Third, the central bank may need to refine how it buys and sells foreign exchange not to interfere too much in the foreign exchange market development.

\section{Improving the Policy and Operational Framework}

In countries that move away from fixed exchange rate regimes, monetary flexibility can increase on different fronts, with varying degrees of complexity:

1. Changing the target for measuring monetary policy success. Price level and inflation targets ${ }^{48}$ provide more flexibility than those on money or exchange rates.

\footnotetext{
${ }^{46}$ See Dutagupta and others, 2004.

${ }^{47}$ See Canales-Kriljenko and others, 2003.

${ }^{48}$ Monetary policy frameworks based on price level targets come in a variety of ways: targeting past inflation, targeting the inflation forecast, targeting the price level or the forecast of the price level, among others.
} 
Focusing on the final nominal objective of inflation would allow money and the exchange rate to move in response to external shocks when they do not move inflation away from its long-run target. Measuring monetary policy success by how close an inflation forecast is to its target, as opposed to the deviations of the price level or inflation from the target, provides even more flexibility.

2. Setting a target range for the measure of success, rather than a point target. The tradeoff is that central banks will hardly ever meet a point target, but such a target provides clearer guidance on when the central bank may need to change the policy rate. Alternatives include incorporating intermediate guides within a range. The width of the target ranges could reflect the volatility of headline inflation around core inflation, or other measures of relative price volatility.

3. Moving the operational target in response to adverse shocks. It is desirable to adopt a monetary policy reaction function, instead of fixing a value for the operational variable and keeping it regardless of the shocks that hit the economy. ${ }^{49}$ The same applies to frameworks that set their operational variables as money or short-term nominal interest rates. ${ }^{50}$ Similarly, instead of keeping the nominal exchange rate fixed all the time, allowing it to move when the economy is, say, facing a shock that will bring about real exchange rate appreciation, could avoid unnecessary volatility on the inflation rate. The trick is to do this systematically and to explain it clearly to the public..$^{51}$

4. Allowing monetary policy decisions to react to short-term deviations in economic activity. This amounts to including the output gap (deviations of economic activity from their long-run potential level) in the monetary policy reaction function. This need not affect inflation expectations because by definition temporary deviations in economic activity will disappear over the forecasting horizon, but could make a significant difference in the short-term. In fact, monetary policy often aims in practice to stabilize economic activity in the short run and inflation in the medium to long run, as suggested by the empirical literature on policy reaction functions.

5. Setting the operational variable as a target rather than the value of the variable. In the former, the authorities, like those in the U.S., conduct operations to keep the

\footnotetext{
${ }^{49} \mathrm{~A}$ reaction function for the policy interest rate could help illustrate the tendency of the board of directors taking policy decisions over time, and can illustrate the effects of behaving in such a way.

${ }^{50}$ Although both short-term interest rates and exchange rates are clearly related, it is in principle possible to set mutually consistent but clearly separate policy reaction functions for these two variables, giving a greater degree of flexibility, but potentially more difficult to monitor and explain to the public. It is also possible to include the exchange rate in the policy interest reaction function and vice versa. In particular, in countries with large system-wide currency exposures associated with financial dollarization, authorities may consider including exchange rate movements (and reserve accumulation) directly into their policy reaction functions.

${ }^{51}$ See Parrado 2004 and Stone and others, 2009.
} 
operational variable at the target range. However, they may let the market deviate temporarily under certain circumstances, for example in response to expectations that the central bank may consider unfounded. Setting the operational variable as a target gives more flexibility but keeping it on target sends a stronger signal.

\section{On Managing Macro-financial Vulnerabilities}

Under any monetary policy regime, macro-financial vulnerabilities need to be low for the central bank to run consistently a credible and flexible monetary policy. With low vulnerabilities, firms and households can safely expect the central bank to keep inflation low. These low inflation expectations are those that allow the central bank to move in the most convenient front in reaction to adverse shocks.

In turn, the strong anchor on inflation expectations allows countries to reduce macroeconomic vulnerabilities. For instance, low inflation expectations allow the government to increase the share and maturity of public debt denominated in domestic currency, at interest rates consistent with the inflation target. A credible and flexible monetary policy framework that anchors inflation expectations can also help to gradually reduce financial dollarization, as the experience of Peru would suggest. Finally, the resulting low dollarization of public debt and bank balance sheets provides more leeway for exchange rate flexibility, which could help discourage large destabilizing capital flows during periods of easy external financial conditions.

Independent fiscal and prudential policy frameworks need to keep vulnerabilities low to be consistent with low inflation. The central banks can only be sure to be able to keep inflation low when fiscal positions are strong and financial institutions are sound. Otherwise, it may have to print money to avoid a worse outcome. Fiscal frameworks need to avoid rapidly rising public debt or other liabilities that the central bank may eventually need to monetize. These frameworks can vary in the degree of discretion that they give to the authorities, with the more rules-based embedded, for example, in fiscal responsibility laws or outright fiscal policy rules. Regulating and supervising financial institutions under clear policy frameworks is also a must to avoid large bailout packages. 


\section{REFERENCES}

Barbosa, Nelson 2010, "Latin America: Counter-Cyclical in Brazil: 2008-09," Journal of Globalization and Development, Vol. 1, Issue 1, Article 13. Pp. 1-14.

Bogdanski, Joel, Alexandre Antonio Tombini, and Sérgio Ribeiro da Costa Werlang, 2000, "Implementing Inflation Targeting in Brazil," Working Paper 1, Banco Central do Brasil.

Borio Claudio and Piti Disyatat, 2009, "Unconventional monetary policies: an appraisal, BIS Working Papers No 292 (November).

Canales-Kriljenko Jorge Ivan, Charles Freedman, Roberto Garcia-Saltos, and Douglas Laxton, 2008, "Adding Latin America to the Global Projection Model," IMF Working Paper 09/85 (Washington D.C.: International Monetary Fund).

Canales-Kriljenko, Jorge Ivan, Turgut Kışınbay, Rodolfo Maino, and Eric Parrado, 2006, "Setting the Operational Framework for Producing Inflation Forecasts," IMF Working Paper 06/122 (Washington D.C.: International Monetary Fund).

Canales-Kriljenko, Jorge Ivan, forthcoming, "The Impact of External Developments on Emerging Markets: The Role of Exchange Rate Flexibility," IMF Working Paper (Washington D.C.: International Monetary Fund).

Carabenciov, I., Ermolaev, C., Freedman, M., Julliard, O., Kamenik, D. , Korsunov, and D. Laxton, 2008, “A Small Quarterly Multicountry Projection Model," IMF Working Paper 08/279 (Washington D.C.: International Monetary Fund).

Carstens, Agustín and Luis I. Jácome H., 2005, "Latin American Central Bank Reform: Progress and Challenges," IMF Working Paper 05/114 (Washington D.C.: International Monetary Fund).

Céspedes C., Luis Felipe and Rodrigo Valdés P., 2006, Autonomía de Bancos Centrales: La Experiencia Chilena, Revista de Economía, Volumen 9 - Nº 1 (abril). Electronically available at http://www.bcentral.cl/estudios/revistaeconomia/2006/abr/Vol9N1abr2006pp25_47.pdf.

Cowan, Kevin, Andrew Filardo, Pablo García, and Hans Genberg, 2009, "IT in Financially Stable Economies: Has it been Flexible Enough?," paper presented at the Decimotercera Conferencia Anual del Banco Central de Chile: Política Monetaria bajo Turbulencia Financiera (November). Electronically available at http://www.bcentral.cl/conferencias-seminarios/conferenciasanuales/2009/Cowan_Garcia.pdf.

Crowe, Christopher and Ellen Meade, 2008, "Central Bank Independence and Transparency: Evolution and Effectiveness," European Journal of Political Economy, Vol. 24, (December), pp. 763-777. 
Cukierman, Alex, Steven Webb, and Bilin Neyapti, 1992, "Measuring the independence of central banks and its effect on policy outcomes." The World Bank Economic Review Vol. 6, pp. 352--398.

Duttagupta, Rupa , Gilda Fernandez, and Cem Karacadag, 2004," From Fixed to Float: Operational Aspects of Moving Towards Exchange Rate Flexibility," IMF Working Paper No. 04/126, July (Washington D.C.: International Monetary Fund).

Gredig U., Fabián, Klaus Schmidt-Hebbel D., and Rodrigo O. Valdés P., 2008, "El Horizonte de la Política Monetaria en Chile y otros Países con Metas de Inflación," Revista de Economia, Vol. 11, No 1 (April).

Habermeier, Karl, İnci Ötker-Robe, Luis I. Jácome, Alessandro Giustiniani, Kotaro Ishi, David Vávra, Turgut Kışınbay, and Francisco Vázquez , 2009, “Inflation Pressures and Monetary Policy Options in Emerging and Developing Countries: A Cross Regional Perspective,” IMF Working Paper, 09/1, (Washington D.C.: International Monetary Fund).

Heenan, Geoffrey, Marcel Peter, and Scott Roger, 2006, "Implementing Inflation Targeting: Institutional Arrangements, Target Design, and Communications,” IMF Working Paper 06/278 (Washington D.C.: International Monetary Fund).

International Monetary Fund, 2009, "Fiscal Policy Response to the Crisis: How Much Space for Countercyclical Policy?” in Regional Economic Outlook Western HemisphereCrisis averted - What's next? (October), (Washington D.C.; International Monetary Fund).

_ 2010, "Challenges Arising from Easy External Financial Conditions" in Regional Economic Outlook Western Hemisphere- Taking Advantage of Tailwinds? (May), (Washington D.C.; International Monetary Fund).

Ishi, Kotaro, Mark Stone, and Etienne B. Yehoue, 2009, "Unconventional Central Bank Measures for Emerging Economies,” IMF Working Paper 09/226 (Washington D.C., International Monetary Fund).

Jácome, Luis I., 2008, “Central Bank Involvement in Banking Crises in Latin America,” IMF Working Paper 08/135, (Washington D.C., International Monetary Fund).

Jácome, Luis I. and Francisco Vázquez, 2008, "Any Link Between Legal Central Bank Independence and Inflation? Evidence from Latin America and the Caribbean," European Journal of Political Economy, Vol. 24, (December), pp. 788-801.

Jácome, Luis I., Marcela Matamoros-Indorf, Mrinalini Sharma, and Simon Townsend, 2010, "Central Bank Credit to the Government: What can we Learn from International Practices?" Unpublished (Washington D.C., International Monetary Fund). 
Kaminsky, Graciela and Carmen Reinhart, 1998, "Financial Crises in Asia and Latin America: Then and Now" (with Carmen Reinhart), American Economic Review, Vol. 88, (May), pp. 444-449.

_ 1999, "The Twin Crises: The Causes of Banking and Balance-of-Payments Problems," American Economic Review Vol. 89 (May), pp. 473-500.

Leiderman, Leonardo, Rodolfo Maino, and Eric Parrado, 2006, "Inflation Targeting in Dollarized Economies," IMF Working Paper 06/157 (Washington D.C.: International Monetary Fund).

Marshall R., Enrique, 2010, "Estrategia de Política Monetaria del Banco Central de Chile Durante esta Crisis," Mimeo, electronically available at http://www.bcentral.cl/politicas/presentaciones/consejeros/pdf/2010/emr19072010.

Ministerio de Hacienda de Chile, 2010, Informe Anual de Fondos Soberanos, 2009.

Parrado, Eric, 2004, “Singapore`s Unique Monetary Policy: How Does It Work?,” IMF Working Paper 04/10 (Washington D.C., International Monetary Fund).

Rennhack, Robert, 2009, “Global Financial Regulatory Reform: Implications for Latin America and the Caribbean (LAC)," IMF Staff Position Note No. 2009/20 (July).

Roger, Scott, 2009, “Inflation Targeting at 20: Achievements and Challenges," IMF Working Paper 09/236 (Washington D.C., International Monetary Fund).

Stella, Peter, 2005, "Central Bank Financial Strength, Transparency, and Policy Credibility," IMF Staff Papers Volume 52, No. 2 (September), (Washington D.C., International Monetary Fund).

Stone, Mark R., Scott Roger, Anna Nordstrom, Seiichi Shimizu, Turgut Kisinbay, Turgut and Jorge Restrepo, 2007," The Role of the Exchange Rate in Inflation-Targeting Emerging Economies," IMF Occasional Paper No. 267, (November), (Washington D.C., International Monetary Fund).

Stone, Mark R., W. Christopher Walker, and Yosuke Yasui, 2009, "From Lombard Street to Avenida Paulista: Foreign Exchange Liquidity Easing in Brazil in Response to the Global Shock of 2008-09," IMF Working Paper No. 09/259 (November), (Washington D.C.; International Monetary Fund).

Zorn, Lorie and Carolyn Wilkins, 2009, "Bank of Canada Liquidity Actions in Response to the Financial Market Turmoil," Bank of Canada Bank of Canada Review, (Autumn). 


\section{ApPendix I. Key Institutional and Policy Provisions in LA5 Central Banks}

\begin{tabular}{|c|c|c|c|c|c|}
\hline Country & Brazil & Chile & Colombia & Mexico & Peru \\
\hline \multicolumn{6}{|l|}{ Policy mandate } \\
\hline $\begin{array}{l}\text { Central bank } \\
\text { objective }\end{array}$ & $\begin{array}{l}\text { Formulate monetary and credit } \\
\text { policy in order to achieve } \\
\text { economic and social progress } \\
\text { for the country (Law } 4595 / 64) \text {. } \\
\text { To ensure the stability of the } \\
\text { purchasing power of the } \\
\text { currency and the soundness and } \\
\text { efficiency of the financial } \\
\text { system (from the central bank } \\
\text { website, as approved by the } \\
\text { Board in Feb/07). }\end{array}$ & $\begin{array}{l}\text { Preserve the stability of } \\
\text { the currency and the } \\
\text { normal functioning of } \\
\text { internal and external } \\
\text { payments. }\end{array}$ & $\begin{array}{l}\text { Preserve the purchasing } \\
\text { capacity of the currency. }\end{array}$ & $\begin{array}{l}\text { The primary objective of the } \\
\text { Bank of Mexico (Banxico) is to } \\
\text { seek the stability of the } \\
\text { purchasing power of the } \\
\text { currency. Banxico should also } \\
\text { promote the sound development } \\
\text { of the financial system and a } \\
\text { proper functioning of payment } \\
\text { systems. }\end{array}$ & $\begin{array}{l}\text { The purpose of the Reserve } \\
\text { Central Bank of Peru } \\
\text { (BCRP) is to preserve } \\
\text { monetary stability. }\end{array}$ \\
\hline \multicolumn{6}{|l|}{$\begin{array}{l}\text { Governing } \\
\text { rules }\end{array}$} \\
\hline $\begin{array}{l}\text { Structure of the } \\
\text { Board }\end{array}$ & $\begin{array}{l}\text { The Board of the Central Bank } \\
\text { of Brazil (BCB) comprises the } \\
\text { Governor and seven Deputy } \\
\text { Governors with executive } \\
\text { responsibilities. There is also } \\
\text { the National Monetary Council } \\
\text { (CMN), which is the highest } \\
\text { organ in the Brazilian financial } \\
\text { system; its members are the } \\
\text { Minister of Finance (chair), the } \\
\text { Minister of Planning, and the } \\
\text { Governor of the BCB. }\end{array}$ & $\begin{array}{l}\text { The Board of the Central } \\
\text { Bank of Chile (BCC) } \\
\text { comprises five members } \\
\text { (including the Governor). }\end{array}$ & $\begin{array}{l}\text { The Board of the Bank of } \\
\text { the Republic (BoR) } \\
\text { comprises seven members, } \\
\text { including the Minister of } \\
\text { Finance (Chairman of the } \\
\text { Board) and the General } \\
\text { Manager of the BoR } \\
\text { (Governor). }\end{array}$ & $\begin{array}{l}\text { The Board of Governors shall be } \\
\text { made up of five members. There } \\
\text { is a Governor and the remaining } \\
\text { members are called Deputy } \\
\text { Governors. }\end{array}$ & $\begin{array}{l}\text { The BCRP is governed by a } \\
\text { Board that is comprised of } \\
\text { seven members (including } \\
\text { the Governor). }\end{array}$ \\
\hline $\begin{array}{l}\text { Who appoints } \\
\text { the Governor } \\
\text { and its term }\end{array}$ & $\begin{array}{l}\text { The Governor of the BCB is } \\
\text { appointed by the President of } \\
\text { the Republic, subject to } \\
\text { approval by the Senate, with no } \\
\text { specific term. }\end{array}$ & $\begin{array}{l}\text { The Governor of the BCC } \\
\text { is appointed by the } \\
\text { President of the Republic } \\
\text { among the members of the } \\
\text { Board for } 5 \text { years. }\end{array}$ & $\begin{array}{l}\text { The Governor of the BoR is } \\
\text { appointed by the Board for } \\
\text { a 4-year period, and can be } \\
\text { reelected for two } \\
\text { consecutive periods. }\end{array}$ & $\begin{array}{l}\text { The President of the Republic } \\
\text { appoints for } 6 \text { years the } \\
\text { Governor of Banxico from } \\
\text { among the five members of the } \\
\text { Board. }\end{array}$ & $\begin{array}{l}\text { The President of the } \\
\text { Republic appoints the } \\
\text { Governor for the same } \\
\text { administrative term and } \\
\text { Congress ratifies this } \\
\text { appointment. }\end{array}$ \\
\hline $\begin{array}{l}\text { Who appoints } \\
\text { the Board and } \\
\text { their term }\end{array}$ & $\begin{array}{l}\text { The Deputy Governors of the } \\
\text { BCB are appointed by the } \\
\text { President of the Republic, } \\
\text { subject to approval by the } \\
\text { Senate, with no specific term. }\end{array}$ & $\begin{array}{l}\text { The BCC's Board is } \\
\text { appointed by the President } \\
\text { of the Republic, with the } \\
\text { prior approval of the } \\
\text { Senate, for } 10 \text { years. }\end{array}$ & $\begin{array}{l}\text { The President of the } \\
\text { Republic appoints the } \\
\text { members of the Board. } \\
\text { Each President can appoint } \\
\text { only two members of the } \\
\text { Board in his term. }\end{array}$ & $\begin{array}{l}\text { The President of the Republic } \\
\text { with the approval of the } \\
\text { Chamber of Senators, or the } \\
\text { Permanent Commission, where } \\
\text { appropriate, appoints Deputy } \\
\text { Governors for an 8-year term. }\end{array}$ & $\begin{array}{l}\text { Three members are } \\
\text { appointed by the President } \\
\text { of the Republic and three } \\
\text { by Congress, all for the } \\
\text { same } 5 \text { years of the } \\
\text { constitutional period. }\end{array}$ \\
\hline
\end{tabular}




\begin{tabular}{|c|c|c|c|c|c|}
\hline Country & Brazil & Chile & Colombia & Mexico & Peru \\
\hline $\begin{array}{l}\text { Dismissal of } \\
\text { Board members }\end{array}$ & $\begin{array}{l}\text { The members of the Board, } \\
\text { including the Governor, may } \\
\text { be removed at any time by the } \\
\text { President of the Republic. }\end{array}$ & $\begin{array}{l}\text { Prior approval of the } \\
\text { Senate, the President of } \\
\text { the Republic, may remove } \\
\text { any or all Board members, } \\
\text { provided they voted for } \\
\text { resolutions implying a } \\
\text { material breach of the } \\
\text { BCC's mandate. }\end{array}$ & $\begin{array}{l}\text { The members of the Board } \\
\text { have the status of public } \\
\text { servants and, hence, they } \\
\text { are removed by the } \\
\text { President of the Republic, } \\
\text { based upon specific legal } \\
\text { violations. }\end{array}$ & $\begin{array}{l}\text { Board members may be } \\
\text { removed only for a compelling } \\
\text { causes established in Art. } 43 \text { of } \\
\text { the Law of the Bank of Mexico. } \\
\text { The Board of governors takes } \\
\text { the final decision. }\end{array}$ & $\begin{array}{l}\text { Board members can only be } \\
\text { dismissed in case of crime } \\
\text { or serious misconduct. The } \\
\text { resolution is adopted with a } \\
\text { majority of } 2 / 3 \text { of total } \\
\text { members of Congress. The } \\
\text { Board member is given at } \\
\text { least } 10 \text { days to present his } \\
\text { plea of discharge and the } \\
\text { right to defend himself } \\
\text { before a Congress plenary } \\
\text { meeting. }\end{array}$ \\
\hline
\end{tabular}

\section{Operational}

\section{autonomy}

Monetary policy The BCB Board is responsible

formulation

(instructions,

coordination,

consultation

with the

government)

for formulating, monitoring

and controlling monetary

policy, in accordance with the

directions of the CMN. The

$\mathrm{CMN}$ sets the inflation target

and the BCB Board sets - in a

meeting of the Monetary Policy

Committee (Copom) - the

target for the policy rate.

Exchange rate

policy

(formulation and

execution)
The BCB Board is responsible for formulating, monitoring and controlling the exchange rate policy, in accordance with the directions of the $\mathrm{CMN}$.
The $\mathrm{BCC}$ is authorized to regulate the amount of currency and credit in circulation, and the performance of credit transactions. Also to issue regulations regarding monetary, credit, and financial matters.

The $\mathrm{BCC}$ is authorized to regulate foreign exchange transactions and, in general, foreign exchange matters.
The BoR is empowered to formulate and implement monetary and credit policies in order to regulate monetary and liquidity conditions, consistent with its primary objective and in coordination with the general economic policy. Monetary policy is implemented through changes in the policy rate.

The BoR Board is in charge Banxico regulates the foreign of determining exchange rate policy in agreement with the Minister of Finance.
Banxico is in charge of formulating monetary policy to achieve its legal mandate. exchange in line with the guidelines established by the Exchange Commission -made up of the Secretary and

Undersecretary of Finance, another Undersecretary of this Ministry, the Governor of

Banxico, and two more

members of the Board

designated by the Governor. The Commission is chaired by the

Secretary of Finance.
The BCRP is in charge of formulating monetary policy in accordance with its mandate and approve the necessary regulations for its enforcement.
The BCRP is authorized to sell and by foreign currencies -but the law does not explicitly assign powers to the BCRP to formulate and execute exchange rate policy. 


\begin{tabular}{|c|c|c|c|c|c|}
\hline Country & Brazil & Chile & Colombia & Mexico & Peru \\
\hline $\begin{array}{l}\text { Policy rate (what } \\
\text { is, who decides, } \\
\text { and frequency of } \\
\text { meetings to } \\
\text { decide) }\end{array}$ & $\begin{array}{l}\text { The policy rate is the average } \\
\text { rate of the overnight repos with } \\
\text { collateral in government } \\
\text { securities. Such operations are } \\
\text { recorded in the Selic system, } \\
\text { the CSD for government } \\
\text { securities. The policy rate is } \\
\text { known as the Selic rate. The } \\
\text { Copom meets eight times a } \\
\text { year on pre-announced dates. }\end{array}$ & $\begin{array}{l}\text { The Monetary Policy Rate } \\
\text { (TPM), an interbank } \\
\text { interest rate, is the } \\
\text { operational variable. The } \\
\text { Council meets monthly, } \\
\text { on pre-announced dates, } \\
\text { to decide on possible } \\
\text { changes to the TPM. }\end{array}$ & $\begin{array}{l}\text { The policy rate is the floor } \\
\text { rate for the daily overnight } \\
\text { repo-expansionary- } \\
\text { auctions. Decisions about } \\
\text { changes in the policy rate } \\
\text { correspond to the Board } \\
\text { during its monthly meeting, } \\
\text { which take place on pre- } \\
\text { announced dates. }\end{array}$ & $\begin{array}{l}\text { Banxico uses the overnight } \\
\text { interbank interest rate as its } \\
\text { operational variable. The Board } \\
\text { of Governors meets on pre- } \\
\text { announced monthly dates to } \\
\text { assess possible changes in the } \\
\text { policy rate. }\end{array}$ & $\begin{array}{l}\text { The BCRP uses the } \\
\text { referential interest rate as } \\
\text { an operational variable to } \\
\text { guide overnight interbank } \\
\text { rates. This interest rate is } \\
\text { defined by the Board } \\
\text { during their monthly } \\
\text { meetings, which take place } \\
\text { on pre-announced dates. }\end{array}$ \\
\hline $\begin{array}{l}\text { Credit to the } \\
\text { government }\end{array}$ & $\begin{array}{l}\text { The BCB cannot finance, } \\
\text { directly or indirectly, the } \\
\text { government. It is allowed to } \\
\text { buy government securities, but } \\
\text { only to refinance those in its } \\
\text { portfolio that are coming due. }\end{array}$ & $\begin{array}{l}\text { The BCC cannot finance } \\
\text { directly or indirectly to the } \\
\text { government, except in } \\
\text { case of a foreign war, as } \\
\text { determined by the } \\
\text { National Security Council. }\end{array}$ & $\begin{array}{l}\text { BoR is authorized to grant } \\
\text { credits to the Central } \\
\text { Government with } \\
\text { unanimous approval of the } \\
\text { Board. }\end{array}$ & $\begin{array}{l}\text { Banxico may grant credit to the } \\
\text { Federal Government up to } \\
1.5 \text { percent of the Federal } \\
\text { Government's expenses as laid } \\
\text { out in the Federal Expense } \\
\text { Budget for the corresponding } \\
\text { year, not taking debt } \\
\text { amortization into consideration. }\end{array}$ & $\begin{array}{l}\text { The Bank is prohibited } \\
\text { from granting credit to the } \\
\text { Government, except for the } \\
\text { purchase, in the secondary } \\
\text { market, of securities } \\
\text { emitted by the Public } \\
\text { Treasury. These securities } \\
\text { cannot exceed } 5 \text { percent of } \\
\text { the money base. }\end{array}$ \\
\hline $\begin{array}{l}\text { Central bank } \\
\text { capital integrity }\end{array}$ & $\begin{array}{l}\text { Central bank profits are } \\
\text { considered income of the } \\
\text { National Treasury and must be } \\
\text { transferred in ten business days } \\
\text { once BCB's financial } \\
\text { statements are approved each } \\
\text { semester. BCB losses are } \\
\text { considered a Treasury liability } \\
\text { to the BCB and are included in } \\
\text { the-next year-government } \\
\text { budget. }\end{array}$ & $\begin{array}{l}\text { The capital of the BCC } \\
\text { may be increased by } \\
\text { capitalizing reserves, } \\
\text { decided by the majority of } \\
\text { the Council members. The } \\
\text { Council can also request } \\
\text { from the Minister of } \\
\text { Finance the increase of its } \\
\text { capital or specific } \\
\text { contributions to its assets } \\
\text { on account of funds to be } \\
\text { appropriated under the } \\
\text { Nation's Budget Act. }\end{array}$ & $\begin{array}{l}\text { BoR losses are covered } \\
\text { with funds previously } \\
\text { accumulated in the } \\
\text { monetary and exchange } \\
\text { stabilization reserve. The } \\
\text { government will provide } \\
\text { the remaining resources } \\
\text { needs to reestablish the } \\
\text { BoR's capital integrity. }\end{array}$ & $\begin{array}{l}\text { Banxico hands over to the } \\
\text { Federal Government the full } \\
\text { amount of its operating surplus } \\
\text { after having provisioned the } \\
\text { reserves set forth in its Law. The } \\
\text { Government is not entitled to } \\
\text { restore Banxico's capital if } \\
\text { needed. }\end{array}$ & $\begin{array}{l}\text { In the case of a loss of } \\
\text { capital, the CBRP's legal } \\
\text { reserves are charged. If the } \\
\text { reserves are insufficient, } \\
\text { within thirty days of the } \\
\text { approval of the balance } \\
\text { sheet, the Treasury issues } \\
\text { and delivers to the Bank } \\
\text { nonnegotiable interest- } \\
\text { bearing debt securities } \\
\text { equivalent to the } \\
\text { outstanding amount. }\end{array}$ \\
\hline \multicolumn{6}{|l|}{ Accountability } \\
\hline $\begin{array}{l}\text { Accountability } \\
\text { procedures } \\
\text { (appearances in } \\
\text { Congress, } \\
\text { inflation report) }\end{array}$ & $\begin{array}{l}\text { The governor of the BCB } \\
\text { appears before Congress within } \\
90 \text { days after the end of each } \\
\text { semester, to assess the } \\
\text { fulfillment of the objectives } \\
\text { and targets of the monetary, } \\
\text { exchange rate and credit }\end{array}$ & $\begin{array}{l}\text { The BCC informs the } \\
\text { President of the Republic } \\
\text { and the governor appears } \\
\text { before the Senate four } \\
\text { times a year, after the } \\
\text { BCC issues the monetary } \\
\text { policy report. }\end{array}$ & $\begin{array}{l}\text { The BoR is legally required } \\
\text { to present, within ten days } \\
\text { of the start of each period } \\
\text { of ordinary sessions, a } \\
\text { report to the Congress on } \\
\text { the implementation of } \\
\text { monetary, exchange, and }\end{array}$ & $\begin{array}{l}\text { Banxico is legally required to } \\
\text { report to the executive and } \\
\text { Congress as follows: (i) the } \\
\text { monetary policy to be followed } \\
\text { during the respective year and a } \\
\text { report on Banxico's budget for } \\
\text { the year (January); (ii) a }\end{array}$ & $\begin{array}{l}\text { According to the } \\
\text { Constitution, the BCRP has } \\
\text { to inform the country, } \\
\text { punctually and periodically, } \\
\text { of the status of national } \\
\text { finances, under the } \\
\text { responsibility of the Board. }\end{array}$ \\
\hline
\end{tabular}




\begin{tabular}{|c|c|c|c|c|c|}
\hline Country & Brazil & Chile & Colombia & Mexico & Peru \\
\hline & $\begin{array}{l}\text { policies, and to present BCB's } \\
\text { financial statements. If the } \\
\text { BCB fails to achieve the } \\
\text { inflation target, the governor } \\
\text { must explain why and what } \\
\text { will be the corrective actions in } \\
\text { an open letter to the Minister of } \\
\text { Finance. The BCB publishes a } \\
\text { quarterly inflation report. }\end{array}$ & & $\begin{array}{l}\text { credit policies. The report } \\
\text { includes an evaluation of } \\
\text { the results achieved during } \\
\text { the preceding period, and } \\
\text { the objectives for the } \\
\text { subsequent period and in } \\
\text { the medium term. The BoR } \\
\text { issues and disseminates an } \\
\text { inflation report on a } \\
\text { quarterly basis. }\end{array}$ & $\begin{array}{l}\text { monetary policy report } \\
\text { implementation during the first } \\
\text { semester of the year } \\
\text { (September); and (iii) a report } \\
\text { on monetary policy } \\
\text { implementation during the } \\
\text { second semester of the previous } \\
\text { year (April). Banxico also issues } \\
\text { a quarterly inflation report and } \\
\text { an annual financial stability } \\
\text { report. }\end{array}$ & $\begin{array}{l}\text { The Board also submits to } \\
\text { the Minister of Economy } \\
\text { and Finance a report } \\
\text { regarding all aspects of the } \\
\text { economic policy that } \\
\text { negatively affect such } \\
\text { endeavor. The BCRP } \\
\text { publishes a quarterly } \\
\text { inflation report and a } \\
\text { financial stability report } \\
\text { once or twice a year. }\end{array}$ \\
\hline $\begin{array}{l}\text { Disclosure of } \\
\text { financial } \\
\text { statements }\end{array}$ & $\begin{array}{l}\text { The financial statements of the } \\
\text { BCB are published in the } \\
\text { website every month, and they } \\
\text { are presented to Congress after } \\
\text { the end of each semester (see } \\
\text { above). }\end{array}$ & $\begin{array}{l}\text { The BCC prepares a } \\
\text { report containing its } \\
\text { financial statements, } \\
\text { audited by an external } \\
\text { firm. The report is } \\
\text { available to the public and } \\
\text { submitted to the Minister } \\
\text { of Finance and the Senate } \\
\text { before end- April of each } \\
\text { year. }\end{array}$ & $\begin{array}{l}\text { The BoR's financial } \\
\text { statements are published in } \\
\text { widely circulated national } \\
\text { newspapers within one } \\
\text { month following the date of } \\
\text { their approval by the } \\
\text { Board, which requires the } \\
\text { authorization of the } \\
\text { Superintendency of Banks. }\end{array}$ & $\begin{array}{l}\text { The Secretary of Finance with } \\
\text { the approval of the Chamber of } \\
\text { Deputies' Finance Accounting } \\
\text { Vigilance Commission } \\
\text { designates Banxico's external } \\
\text { auditor (selected from three } \\
\text { prestigious accounting firms } \\
\text { nominated by the accountants' } \\
\text { official organization). Banxico } \\
\text { publishes financial statements at } \\
\text { end of the year and consolidated } \\
\text { statements on the last day of } \\
\text { every month. }\end{array}$ & $\begin{array}{l}\text { After approval by the } \\
\text { Board, the CBRP publishes } \\
\text { their financial statements in } \\
\text { the official gazette, audited } \\
\text { and certified by the Chief } \\
\text { of the Internal Control } \\
\text { Unit. The BCRP also } \\
\text { publishes each month a } \\
\text { summary of its balance } \\
\text { sheet in the official gazette. }\end{array}$ \\
\hline $\begin{array}{l}\text { Disclosure of } \\
\text { policy decisions }\end{array}$ & $\begin{array}{l}\text { Copom decisions are disclosed } \\
\text { in a communiqué after } 6 \mathrm{pm} \\
\text { when the two-day meeting } \\
\text { finishes. The minutes are } \\
\text { disclosed within six days after } \\
\text { the meetings. }\end{array}$ & $\begin{array}{l}\text { The BCC discloses a } \\
\text { communiqué following } \\
\text { the monthly meeting of } \\
\text { the Council. It also posts } \\
\text { in its website information } \\
\text { about all other policy } \\
\text { decisions adopted. The } \\
\text { BCC publishes minutes of } \\
\text { the policy meetings and } \\
\text { voting patterns. }\end{array}$ & $\begin{array}{l}\text { The BoR discloses a } \\
\text { communiqué following the } \\
\text { monthly meeting of the } \\
\text { Board and posts in its } \\
\text { website this and other } \\
\text { relevant information. It also } \\
\text { publishes minutes of the } \\
\text { policy meetings. }\end{array}$ & $\begin{array}{l}\text { Banxico discloses a } \\
\text { communique following the } \\
\text { monthly meeting of the Board } \\
\text { and posts in its website this and } \\
\text { other relevant information. }\end{array}$ & $\begin{array}{l}\text { The BCRP discloses a } \\
\text { communiqué following the } \\
\text { monthly meeting of the } \\
\text { Board and posts in its } \\
\text { website this and other } \\
\text { relevant information. }\end{array}$ \\
\hline
\end{tabular}




\section{APPENDIX II. EXPANDED CWN INDEX}

\section{Expanded CWN Index */}

Central Bank Board (0.20)

1. Term of office of Governor (0.15)

- More than the presidential/Prime Minister period

- Same period as the presidential term but with overlap

- Same period as the presidential term or not specified in law

- Less than the presidential term

2. Who appoints the Governor (0.15)

- Double process (Executive/Legislative), through an independent Central Bank Board, or by the King

- The executive branch directly or through a non-independent Central Bank Board

3. Term of office of the rest of the Board (0.20)

- More than presidential/Prime Minister period

- For the same period as the presidential term with overlap

- For the same period as the presidential term

- For less than the presidential term

4. Who appoints the rest of the Board (0.20)

- Double process (executive/legislative)

- The executive and legislative appoint (with majority from the legislative), or the King

- The executive and legislative appoint (with majority from the executive)

- The executive branch appoints

- The private sector nominates/appoints -or is consulted- some members

5. Dismissal of Board members (0.25)

- Double process approved by the Legislative for violations codified in legislation

- By an independent Central Bank Board

- By the executive branch or Central Bank Board due to legal reasons

- Double process approved by the Legislative, based on policy decisions or due to subjective reasons

- By the executive branch or the Central Bank Board due to policy or subjective reasons, or if no legal provision exists

6. CEO allowed to hold another office in government (0.05)

- Prohibited by law

- Not allowed unless authorized by executive branch

- No prohibition for holding another office

\section{Central Bank objectives (0.15)}

\section{Fundamental objective (1.00)}

- Price stability is the single or primary objective 


\section{Expanded CWN Index */}

- Price stability plus financial system, without priority

- Price stability together with exchange rate stability, but without priority

- Price stability together with objective of economic growth / economic development with no priority

- Objectives do not include price stability

\section{Policy formulation (0.15)}

8. Who formulates monetary policy (0.50)

- Central Bank has explicit, or de facto, authority via its mandate or functions

- The Central Bank and the executive branch participate, but the former holds the final decision

- Central Bank participates on monetary policy formulation in an advisory capacity or faces legal limitations on monetary instruments or interest rates

- Government formulates monetary policy and central bank executes

\section{Exchange rate policy (0.25)}

- The government determines -or participates on defining- the exchange rate regime, but the Central Bank is autonomous to formulate and execute

- The Central Bank and the executive branch participate in policy formulation, but the former holds the final decision

- The Central Bank and the executive branch participate in policy formulation, but the government holds the final decision

- Government formulates exchange rate policy and the Central Bank executes

10. Government directives and resolution of conflicts (0.25)

- Central Bank given, explicitly or de facto, final authority over issues defined in the law as objectives

- Government has final authority only over policy issues that have not been clearly defined as Central Bank goals

- Final decision up to a council whose members are from the Central Bank, executive branch, and legislative branch over issues not clearly defined as Central Bank objectives, or if the final decision imposes limitations on its operations

- Legislative branch has final authority

- Executive branch has final authority, but subject to due process and possible protest by Central Bank

- Executive branch has unconditional authority over policy

\section{Central Bank lending (0.25)}

\section{Limitations on advances (0.15)}

- Advances to the government prohibited

- Limited by small percentage of government revenues/expenditures or by the monetary program

- Allowed under lax limits (more than 15\% of government revenues)

- Allowed without limits

\section{Lending to the Government (0.30)}

- Not allowed or in the secondary market for monetary policy purposes

- In the primary market with limits or approved by the Central Bank Board with a qualified majority 


\section{Expanded CWN Index */}

13. Who decides about interest rates (0.25)

- Central Bank defines terms and conditions or at market conditions

- Defined by law

- Not specified in law

- The law allows negotiations between government and Central Bank

- Executive has the final decision

14. Beneficiaries of Central Bank financing (0.10)

- Only the government

- Government plus local governments

- All of the above plus public enterprises

- All of the above and to the private sector

15. Maturity of loans (0.20)

- Limited to a maximum of 90 days

- Limited to a maximum of 180 days

- Paid back within the same fiscal year or defined by the Central Bank Board

- Paid back within a given period in the next fiscal year

- No legal upper bounds

\section{Financial autonomy $((0.10)$}

\section{Central bank capital (0.60)}

- Government should maintain Central Bank capital integrity

- Government is legally allowed to capitalize the Central Bank (not mandatory)

- The law does not allow the government to capitalize the Central Bank or there is no legal provision

- The Central Bank conducts quasi-fiscal operations.

17. Approval of Central Bank budget (0.40)

- The Central Bank Board approves

- There is no legal provision saying who approves the budget or the executive branch approves

- The Parliament approves

\section{Accountability and transparency (0.15)}

18. Central Bank reporting (0.50)

- The Central Bank Governor appears before Congress to report about monetary policy achievements.

- The Central Bank Governor reports to the executive once a year and submits an annual report to Congress.

- Distributes an annual report without establishing particular period of time for it. 


\begin{tabular}{lc}
\hline Expanded CWN Index */ & 1 \\
\hline - Discloses detailed financial statements at least once a year with a certification of an independent auditor & 0.75 \\
- Discloses financial statements at least once a year with seal of the Banking Superintendent or other public sector \\
authority \\
- Discloses financial statements at least once a year certified by an internal auditor \\
- Publishes partial financial statements \\
- Does not publish financial statements or the law authorizes the central bank to deviate from international \\
accounting standards \\
20. Explanation and dissemination of policy decisions (0.25) \\
- The Central Bank is required to explain and disseminate policy decisions immediately after having been adopted \\
- The Central Bank is required to publish policy decisions in the official gazette \\
- The Central Bank is required to publish statistics, but not policy decisions \\
- There is no legal provision in this respect
\end{tabular}

*/ Based on the Cukierman, Webb, and Neyapti index (1992). 
APPENDIX III. LA5, SELECTED ECONOMIC INDICATORS

Real GDP growth

External current account balance

End of year gross stock of official reserve assets End of year gross stock of official reserve assets

Local currency per U.S. dollar exchange rate (average) Real effective exchange rate

General government debt - owed to domestic holders

General government debt - owed to foreign holders $/ 1$

Public sector balance

Public sector balance - excluding interest

Public sector debt - denominated in foreign currency $/ 1$ Real GDP growth index

End of year $\mathrm{CPI}$ index value

Real GDP growth

External current account balance

End of year gross stock of official reserve assets

End of year gross stock of official reserve assets

Local currency per U.S. dollar exchange rate (average)

Real effective exchange rate

General government debt - owed to domestic holders

General government debt - owed to foreign holders

Public sector balance

Public sector balance - excluding interest

Public sector debt - denominated in foreign currency

Real GDP growth index

End of year CPI index value

Real GDP growth

External current account balance

End of year gross stock of official reserve assets

End of year gross stock of official reserve assets

Local currency per U.S. dollar exchange rate (average)

Real effective exchange rate

General government debt - owed to domestic holders

General government debt - owed to foreign holders

Public sector balance

Public sector balance - excluding interest

Public sector debt - denominated in foreign currency

Real GDP growth index

End of year CPI index value
Brazil

Percent

Percent of GDP

USDs, billions

Percent of GDP

Nat. Curr. per USD

Year $2005=100$

Percent of GDP

Percent of GDP

Percent of GDP

Percent of GDP

Percent of GDP

Year $2000=100$

Year $2000=100$

\begin{tabular}{rrrrrrrrrr}
2000 & 2001 & 2002 & 2003 & 2004 & 2005 & 2006 & 2007 & 2008 & 2009 \\
\hline 4.3 & 1.3 & 2.7 & 1.1 & 5.7 & 3.2 & 4.0 & 6.1 & 5.1 & -0.2 \\
-3.8 & -4.2 & -1.5 & 0.7 & 1.8 & 1.6 & 1.3 & 0.1 & -1.7 & -1.5 \\
33.0 & 35.9 & 37.8 & 52.9 & 49.3 & 53.8 & 85.8 & 180.3 & 193.8 & 239.2 \\
5.1 & 6.5 & 7.5 & 9.6 & 7.4 & 6.1 & 7.9 & 13.2 & 11.8 & 15.2 \\
1.8 & 2.3 & 2.9 & 3.1 & 2.9 & 2.4 & 2.2 & 1.9 & 1.8 & 2.0 \\
99.8 & 84.0 & 82.0 & 77.2 & 81.6 & 100.0 & 112.1 & 121.5 & 128.1 & 128.6 \\
49.8 & 53.8 & 57.7 & 58.1 & 57.3 & 58.9 & 59.4 & 60.1 & 58.8 & 65.1 \\
13.3 & 13.9 & 19.2 & 14.2 & 11.4 & 8.9 & 6.4 & 4.4 & 4.8 & 3.5 \\
-3.4 & -3.3 & -4.4 & -5.1 & -2.8 & -3.4 & -3.5 & -2.7 & -1.4 & -3.3 \\
3.2 & 3.4 & 3.2 & 3.3 & 3.8 & 3.9 & 3.2 & 3.4 & 4.0 & 2.1 \\
28.2 & 24.9 & 27.7 & 18.6 & 13.5 & 10.1 & 7.5 & 4.9 & 5.3 & 3.9 \\
100.0 & 101.3 & 104.0 & 105.2 & 111.2 & 114.7 & 119.3 & 126.5 & 133.0 & 132.8 \\
100.0 & 107.7 & 121.2 & 132.4 & 142.5 & 150.6 & 155.3 & 162.3 & 171.8 & 179.2
\end{tabular}

$2000 \quad 2001 \quad 2002 \quad 2003 \quad 2004$

Percent

Percent of GDP

USDs, billions

Percent of GDP

Nat. Curr. per USD

\begin{tabular}{rrrrrrrrrr}
2000 & 2001 & 2002 & 2003 & 2004 & 2005 & 2006 & 2007 & 2008 & 2009 \\
\hline 4.5 & 3.5 & 2.2 & 4.0 & 6.0 & 5.6 & 4.6 & 4.6 & 3.7 & -1.5
\end{tabular}

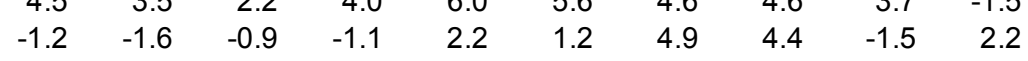

$\begin{array}{llllllllll}15.1 & 14.4 & 15.4 & 15.9 & 16.0 & 17.0 & 19.4 & 16.9 & 23.2 & 25.4\end{array}$

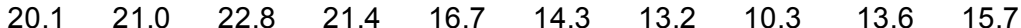

$\begin{array}{llllllllll} & 634.9 & 688.9 & 691.4 & 609.5 & 559.8 & 530.3 & 522.5 & 522.5 & 566.3\end{array}$

$\begin{array}{lrrrrrrrrrr} & & \end{array}$

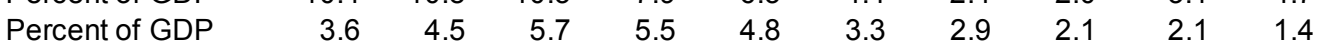

\begin{tabular}{lllllllllll} 
Percent of GDP & -0.7 & -0.5 & -1.2 & -0.4 & 2.1 & 4.7 & 7.9 & 8.9 & 5.3 & -4.4 \\
\hline
\end{tabular}

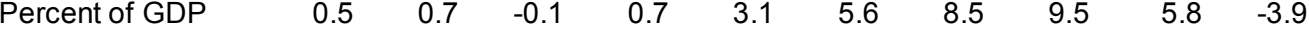

Percent of GDP

$\begin{array}{rrrrrrrrrr}12.4 & 13.9 & 14.7 & 11.8 & 9.0 & 5.2 & 3.6 & 2.1 & 2.1 & 1.4 \\ 100.0 & 103.5 & 105.8 & 110.0 & 116.6 & 123.1 & 128.7 & 134.7 & 139.6 & 137.5\end{array}$

$\begin{array}{llllllllll}100.0 & 102.7 & 105.6 & 106.8 & 109.4 & 113.4 & 116.3 & 125.4 & 134.3 & 132.5\end{array}$

Colombia

Percent

\begin{tabular}{rrrrrrrrrr}
2000 & 2001 & 2002 & 2003 & 2004 & 2005 & 2006 & 2007 & 2008 & 2009 \\
\hline 2.9 & 2.2 & 2.5 & 4.6 & 4.7 & 5.7 & 6.9 & 7.5 & 2.4 & 0.1
\end{tabular}

Percent of GDP

USDs, billions

Percent of GDP

$\begin{array}{llllllllll}0.9 & -1.2 & -1.5 & -1.1 & -0.8 & -1.3 & -1.8 & -2.8 & -2.9 & -1.8\end{array}$

$\begin{array}{llllllllll}9.0 & 10.2 & 10.8 & 10.9 & 13.5 & 15.0 & 15.4 & 21.0 & 24.0 & 25.4\end{array}$

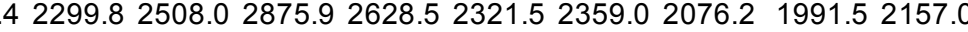

$\begin{array}{lllllllllll}\text { Year 2005 = 100 } & 96.1 & 93.2 & 91.6 & 81.7 & 89.2 & 100.0 & 98.5 & 109.4 & 115.4 & 113.1\end{array}$

$\begin{array}{lllllllllll}\text { Percent of GDP } & 19.1 & 18.0 & 21.7 & 20.4 & 21.8 & 22.4 & 20.5 & 19.0 & 18.5 & 20.0\end{array}$

$\begin{array}{lllllllllll}\text { Percent of GDP } & 23.4 & 25.2 & 28.0 & 25.8 & 20.6 & 16.4 & 15.3 & 13.4 & 13.8 & 15.2\end{array}$

$\begin{array}{lllllllllll}\text { Percent of GDP } & -3.0 & -2.9 & -3.2 & -2.4 & -1.1 & 0.0 & -0.7 & -0.7 & -0.1 & -2.8\end{array}$

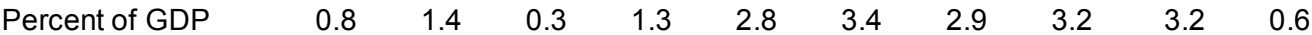

$\begin{array}{lllllllllll}\text { Percent of GDP } & 23.4 & 25.2 & 28.0 & 25.8 & 20.6 & 16.4 & 15.3 & 13.4 & 13.8 & 15.2\end{array}$

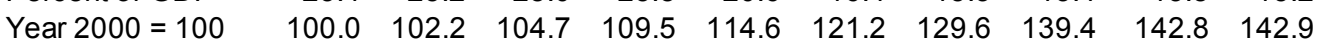

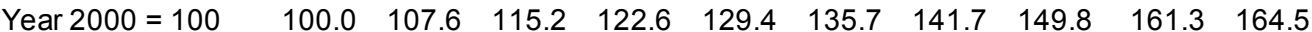


Real GDP growth

External current account balance

End of year gross stock of official reserve assets

End of year gross stock of official reserve assets

Local currency per U.S. dollar exchange rate (average)

Real effective exchange rate

General government debt - owed to domestic holders

General government debt - owed to foreign holders

Public sector balance

Public sector balance - excluding interest

Public sector debt - denominated in foreign currency

Real GDP growth index

End of year CPI index value

\section{Real GDP growth}

External current account balance

End of year gross stock of official reserve assets

End of year gross stock of official reserve assets

Local currency per U.S. dollar exchange rate (average)

Real effective exchange rate

External public sector debt

Domestic public sector debt

Public sector balance

Public sector balance - excluding interest

Public sector debt - denominated in foreign currency

Real GDP growth index

End of year CPI index value
Percent

Percent of GDP

USDs, billions

Percent of GDP

Nat. Curr. per USD

Year $2005=100$

Percent of GDP

Percent of GDP

Percent of GDP

Percent of GDP

Percent of GDP

Year $2000=100$

Year $2000=100$

\begin{tabular}{rrrrrrrrrr}
\multicolumn{10}{c}{ Mexico } \\
2000 & 2001 & 2002 & 2003 & 2004 & 2005 & 2006 & 2007 & 2008 & 2009 \\
\hline 6.6 & -0.2 & 0.8 & 1.7 & 4.0 & 3.2 & 4.9 & 3.3 & 1.5 & -6.5 \\
-3.0 & -2.6 & -2.0 & -1.0 & -0.7 & -0.5 & -0.5 & -0.8 & -1.5 & -0.6 \\
35.6 & 44.8 & 50.7 & 59.0 & 64.2 & 74.1 & 76.3 & 87.2 & 95.3 & 99.9 \\
5.7 & 6.7 & 7.2 & 8.4 & 8.4 & 8.7 & 8.0 & 8.5 & 8.7 & 11.4 \\
9.5 & 9.3 & 9.7 & 10.8 & 11.3 & 10.9 & 10.9 & 10.9 & 11.1 & 13.5 \\
104.7 & 111.3 & 111.4 & 99.7 & 95.9 & 100.0 & 100.2 & 99.1 & 97.5 & 85.3 \\
29.3 & 30.1 & 30.3 & 29.6 & 26.8 & 27.1 & 28.2 & 27.9 & 30.4 & 32.8 \\
16.2 & 14.2 & 15.6 & 16.0 & 14.6 & 12.8 & 10.2 & 10.3 & 12.9 & 12.1 \\
-3.3 & -3.3 & -3.6 & -2.4 & -1.5 & -1.4 & -1.0 & -1.4 & -1.5 & -4.7 \\
1.3 & 1.0 & -0.1 & 0.7 & 1.4 & 1.5 & 1.8 & 1.3 & 1.1 & -2.0 \\
16.2 & 14.2 & 15.6 & 16.0 & 14.6 & 12.8 & 10.2 & 10.3 & 12.9 & 12.1 \\
100.0 & 99.8 & 100.7 & 102.4 & 106.5 & 109.9 & 115.3 & 119.1 & 120.9 & 113.0 \\
100.0 & 104.4 & 110.2 & 114.5 & 120.3 & 124.3 & 129.3 & 134.1 & 142.8 & 147.9 \\
& & & & Peru & & & & \\
2000 & 2001 & 2002 & 2003 & 2004 & 2005 & 2006 & 2007 & 2008 & 2009 \\
\hline 3.0 & 0.2 & 5.0 & 4.0 & 5.0 & 6.8 & 7.7 & 8.9 & 9.8 & 0.9 \\
-2.8 & -2.1 & -1.9 & -1.5 & 0.0 & 1.4 & 3.1 & 1.3 & -3.7 & 0.2 \\
8.4 & 8.8 & 9.7 & 10.2 & 12.6 & 14.1 & 17.3 & 27.7 & 31.2 & 33.2 \\
15.8 & 16.4 & 17.1 & 16.6 & 18.1 & 17.8 & 18.8 & 25.9 & 24.5 & 26.2 \\
3.5 & 3.5 & 3.5 & 3.5 & 3.4 & 3.3 & 3.3 & 3.1 & 2.9 & 3.0 \\
102.2 & 105.6 & 106.6 & 102.6 & 100.8 & 100.0 & 98.2 & 96.5 & 100.8 & 104.3 \\
$\ldots$ & $\ldots$ & $\ldots$ & $\ldots$ & $\ldots$ & $\ldots$ & $\ldots$ & $\ldots$ & 16.7 & 17.4 \\
$\ldots$ & $\ldots$ & $\ldots$ & $\ldots$ & $\ldots$ & $\ldots$ & $\ldots$ & $\ldots$ & 9.0 & 10.0 \\
-3.3 & -2.2 & -2.2 & -1.7 & -1.1 & -0.3 & 2.2 & 3.1 & 2.1 & -2.0 \\
-0.8 & 0.0 & 0.0 & 0.5 & 1.0 & 1.6 & 4.1 & 4.9 & 3.7 & -0.7 \\
39.3 & 38.8 & 39.6 & 43.3 & 37.5 & 29.5 & 25.0 & 21.3 & 16.2 & 16.8 \\
100.0 & 100.2 & 105.2 & 109.5 & 114.9 & 122.8 & 132.3 & 144.1 & 158.2 & 159.6 \\
100.0 & 99.9 & 101.4 & 103.9 & 107.5 & 108.8 & 110.0 & 114.4 & 122.0 & 122.3 \\
\hline & & & & & & & & &
\end{tabular}

Percent

Percent of GDP

USDs, billions

Percent of GDP

Nat. Curr. per USD

Year $2005=100$

Percent of GDP

Percent of GDP

Percent of GDP

Percent of GDP

Percent of GDP

Year $2000=100$

Year 2000 $=100$

$1 /$ Refers to gross public debt in Brazil. The gross debt of the nonfinancial public sector includes the stock of Treasury bonds held by central bank (about a fourth of the total in 2010). In Brazil, unlike in many other emerging market countries, the central bank is not authorized by law to issue its own debt for open market

operations. 


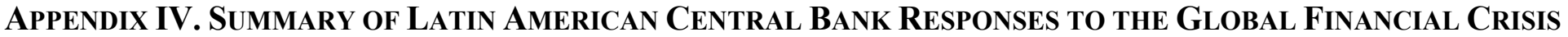

(Period covered: October 2008-July 2009. Unless otherwise indicated, the measures were taken in the last quarter of 2008.)

\begin{tabular}{|c|c|c|c|c|c|}
\hline & Brazil & Chile & Colombia & Mexico & Peru \\
\hline $\begin{array}{l}\text { Liquidity } \\
\text { management in } \\
\text { domestic } \\
\text { currency }\end{array}$ & $\begin{array}{l}\text { - Several measures to reduce } \\
\text { reserve requirements, some of } \\
\text { them conditional on the use of } \\
\text { the freed resources (from Sep } / 08 \\
\text { to Dec/08). }\end{array}$ & $\begin{array}{l}\text { - Broadened eligible repo } \\
\text { collateral. } \\
\text { - Extended regular repo term } \\
\text { to } 28 \text { days. } \\
\text { - Implemented collateralized } \\
\text { credit lines for terms over } 28 \\
\text { days. } \\
\text { - Implemented a } 90 \text { - and } \\
180 \text {-day lending facility } \\
\text { (FLAP) at the } 0.5 \text { percent } \\
\text { policy rate }(\mathrm{Jul} / 09) \text {. }\end{array}$ & $\begin{array}{l}\text { - Reduction of reserve } \\
\text { requirements. }\end{array}$ & $\begin{array}{l}\text { - Broadened eligible } \\
\text { collateral and lowered } \\
\text { cost of overdraft facility. } \\
\text { - Broadened eligible } \\
\text { collateral for liquidity } \\
\text { provision OMOs. } \\
\text { - Buy auctions of IBAP } \\
\text { (deposit insurer) } \\
\text { securities (sterilized). }\end{array}$ & $\begin{array}{l}\text { - Implemented repo } \\
\text { operations with terms of up } \\
\text { to one year. } \\
\text { - Used FX swaps to inject } \\
\text { Sol liquidity. } \\
\text { - Lowered reserve } \\
\text { requirements. }\end{array}$ \\
\hline $\begin{array}{l}\text { Dollar spot } \\
\text { market }\end{array}$ & $\begin{array}{l}\text { - Sales of } 14.3 \text { billion from } \\
\text { Oct } / 08 \text { to Jan/09. }\end{array}$ & $\begin{array}{l}\text { - Stopped USD purchases } \\
\text { (reserve accumulation } \\
\text { program) since Sep/08. }\end{array}$ & $\begin{array}{l}\text { - Stopped daily } \\
\text { purchases of } 20 \text { million } \\
\text { USD. }\end{array}$ & $\begin{array}{l}\text { - Sales through daily } \\
\text { auctions ( } 15.5 \text { billion } \\
\text { from Oct/08 to Jul/09), } \\
\text { extra auctions ( } 11 \text { billion } \\
\text { in Oct } / 08) \text { and directly } \\
\text { (1.8 billion in Feb/09). }\end{array}$ & $\begin{array}{l}\text { - Net sales of } 6.8 \text { billion } \\
\text { from Sep/ } 08 \text { to Feb/09, of } \\
\text { which } 4.6 \text { billion in Sep/ } 08 \\
\text { and Oct } / 08 \text {. }\end{array}$ \\
\hline $\begin{array}{l}\text { Other FX- } \\
\text { related } \\
\text { measures }\end{array}$ & $\begin{array}{l}\text { - Lending of } 9.7 \text { billion through } \\
\text { FX swaps Sep/08 to Jan/ } 09 \text {. } \\
\text { - Trade financing loan auctions } \\
\text { of } 10.6 \text { billion Oct/08 to Mar/ } 09 \text {. } \\
\text { - Established a currency swap } \\
\text { line of } 30 \text { billion USD with the } \\
\text { Fed (Oct/08). }\end{array}$ & $\begin{array}{l}\text { - Implemented FX swaps, } \\
\text { first with a } 28 \text { - then with a } \\
180 \text {-day term. } \\
\text { - Allowed to fulfill USD } \\
\text { reserve requirements using } \\
\text { pesos. }\end{array}$ & $\begin{array}{l}\text { - Eliminated the } \\
\text { unremunerated reserve } \\
\text { requirement on external } \\
\text { debts and pre-financing } \\
\text { of exports. } \\
\text { - Requested a } 10.4 \\
\text { billion USD flexible } \\
\text { credit line (FCL) from } \\
\text { the IMF }(\mathrm{Apr} / 09) \text {. }\end{array}$ & $\begin{array}{l}\text { - Established a currency } \\
\text { swap line of } 30 \text { billion } \\
\text { USD with the Fed } \\
\text { (Oct/08). } \\
\text { - Requested a } 47 \text { billion } \\
\text { USD flexible credit line } \\
\text { (FCL) from the IMF } \\
(\text { Apr/09). }\end{array}$ & $\begin{array}{l}\text { - Created (but did not use) } \\
\text { dollar repos } \\
\text { - Sales of certificates } \\
\text { indexed to USD but settled } \\
\text { in Soles. }\end{array}$ \\
\hline $\begin{array}{l}\text { Use of } \\
\text { derivatives }\end{array}$ & $\begin{array}{l}\text { - Net exposure in non- } \\
\text { deliverable currency swaps } \\
\text { changed from } 22 \text { billion long in } \\
\text { USD Oct/ } 08 \text { to around } 11 \text { billion } \\
\text { short in USD in Dec/ } 08 \text {, then to } \\
\text { no exposure in Jun } / 09 \text {. }\end{array}$ & & $\begin{array}{l}\text { - Reactivated auctions of } \\
\text { "volatility options" to } \\
\text { buy or sell USD, which } \\
\text { led to sales of } 0.6 \text { billion } \\
\text { USD from Oct } / 08 \text { to } \\
\text { Feb/09. }\end{array}$ & $\begin{array}{l}\text { - Interest rate swaps with } \\
\text { commercial banks. }\end{array}$ & \\
\hline
\end{tabular}

Source: Central banks' answers to a questionnaire to the LA5 central banks. 